Florida International University FIU Digital Commons

\title{
Analyzing Spatial Variability of Social Preference for the Everglades Restoration in the Face of Climate Change
}

Abu Hena Mustafa Kamal Sikder

asikd002@fiu.edu

DOI: $10.25148 /$ etd.FIDC000758

Follow this and additional works at: https://digitalcommons.fiu.edu/etd

Part of the Natural Resource Economics Commons, Natural Resources Management and Policy Commons, $\underline{\text { Sustainability Commons, and the Water Resource Management Commons }}$

\section{Recommended Citation}

Sikder, Abu Hena Mustafa Kamal, "Analyzing Spatial Variability of Social Preference for the Everglades Restoration in the Face of Climate Change" (2016). FIU Electronic Theses and Dissertations. 2565.

https://digitalcommons.fiu.edu/etd/2565 


\title{
FLORIDA INTERNATIONAL UNIVERSITY
}

Miami, Florida

\section{ANALYZING SPATIAL VARIABILITY OF SOCIAL PREFERENCE FOR THE} EVERGLADES RESTORATION IN THE FACE OF CLIMATE CHANGE

\author{
A thesis submitted in partial fulfillment of \\ the requirements for the degree of \\ MASTER OF SCIENCE \\ in \\ ENVIRONMENTAL STUDIES \\ by
}

Abu Hena Mustafa Kamal Sikder 
To: Dean Michael R. Heithaus

College of Arts, Sciences and Education

This thesis, written by Abu Hena Mustafa Kamal Sikder, and entitled Analyzing Spatial Variability of Social Preference for the Everglades Restoration in The Face of Climate Change, having been approved in respect to style and intellectual content, is referred to you for judgment.

We have read this thesis and recommend that it be approved.

Assefa Mekonnen Melesse

$\begin{array}{r}\hline \text { Mahadev G. Bhat } \\ \hline \text { Michael C. Sukop } \\ \hline \text { Pallab Mozumder, Major Professor }\end{array}$

Date of Defense: June 16, 2016

The thesis of Abu Hena Mustafa Kamal Sikder is approved.

Dean Michael R. Heithaus

College of Arts, Sciences and Education

Andrés G. Gil

Vice President for Research and Economic Development and Dean of the University Graduate School

Florida International University, 2016 
(C) Copyright 2016 by Abu Hena Mustafa Kamal Sikder

All rights reserved. 


\section{DEDICATION}

I dedicate this thesis to my parents, Ruhumina Zaman and Maniruzzaman Sikder and my wife, Hur-E-Zannat. 


\section{ACKNOWLEDGMENTS}

I am sincerely thankful to my major advisor, Dr. Pallab Mozumder, for his support and guidance. I truly would like to thank him for allowing me to work on the South Florida Water, Sustainability, and Climate project (NSF Award\# 1204762). I would also like to extend my sincere gratitude toward my thesis committee members, Dr. Assefa Melsse, Dr. Mahadev Bhat, and Dr. Michael Sukop for their encouragement and suggestions over the course of this project. I am grateful for their guidance, which helped me overcome several challenges encountered throughout the work. I would like to thank Nadia Seeteram for always being helpful and providing me important information related to the project. Also, I would like to thank the Department of Earth and Environment for awarding me the assistantships that allowed me to complete my graduate degree. I am also very thankful to the Everglades Foundation for awarding me the FIU ForEverglades Scholarship. 
ABSTRACT OF THE THESIS

ANALYZING SPATIAL VARIABILITY OF SOCIAL PREFERENCE FOR THE EVERGLADES RESTORATION IN THE FACE OF CLIMATE CHANGE

by

Abu Hena Mustafa Kamal Sikder

Florida International University, 2016

Miami, Florida

Professor Pallab Mozumder, Major Professor

The South Florida Everglades is a unique ecosystem. Intensive water management in the system has facilitated agricultural, urban, and economic development. The Everglades offers a variety of ecosystem services (ES) to the people living in this region. Nevertheless, the ecosystem is under imminent threat of climate change, which would alter the way water is managed today and ultimately affect the ES offered by the system. On the other hand, substantial restoration is underway that aims to restore the Everglades closer to its historic condition. This research tried to map the public's preference for Everglades restoration. Using a geocoded discrete-choice survey dataset, the study showed variation in the public's preference by changing the levels of ES. Additionally, the general public's attitude toward climate change risk to the Everglades and preference for mitigation were also assessed using the survey data. 


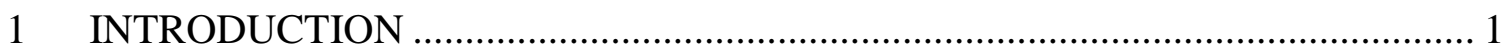

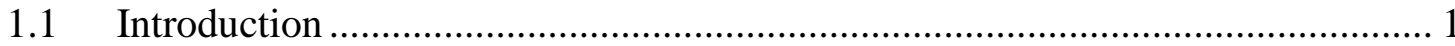

2 SPATIAL MAPPING of PUBLIC PREFERENCE for EVERGLADES

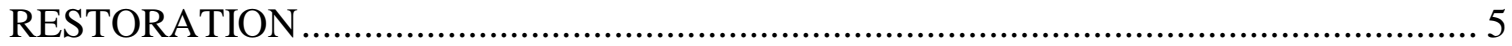

2.1 Ecosystem services and restoration of the Everglades........................................ 5

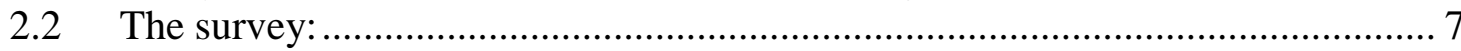

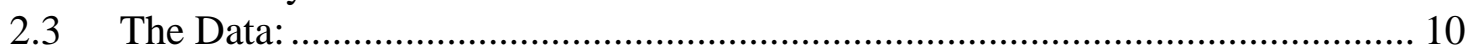

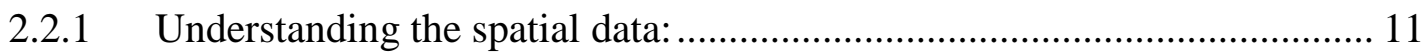

2.4 Spatial interpolation of public's preference for different Ecosystem Services.. 16

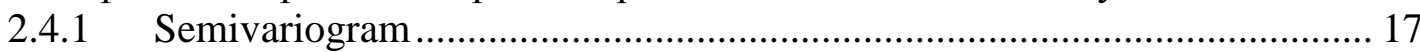

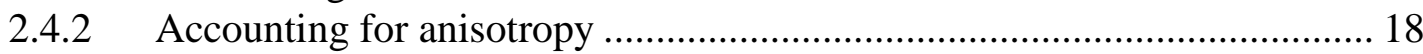

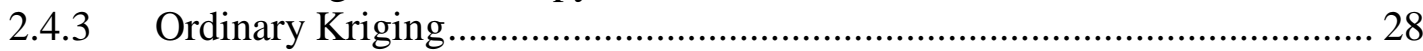

2.5 Generation of preference map .................................................................. 31

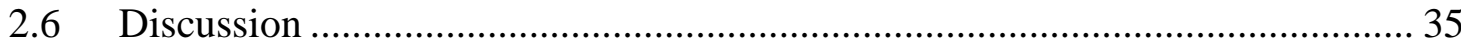

3 RISK PERCEPTIONS REGARDING CLIMATE CHANGE AND SEA LEVEL

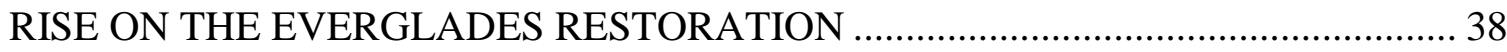

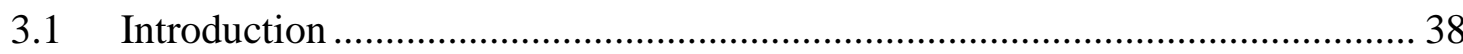

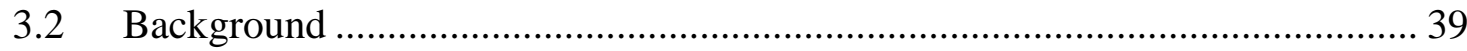

3.3 Survey Design and Data Collection ................................................................. 43

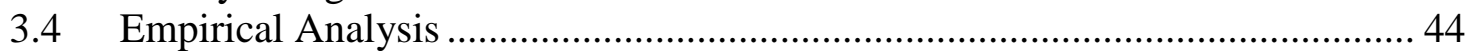

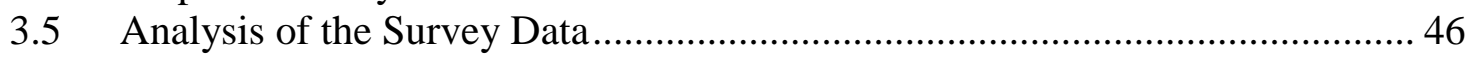

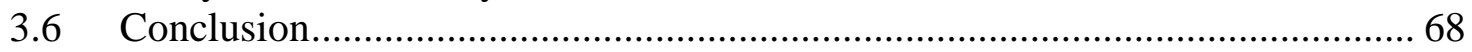

4 DISCUSSION AND CONCLUSION …………............................................ 70

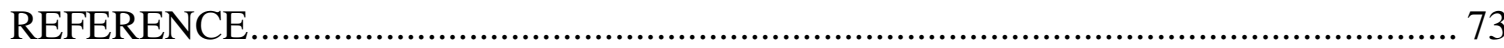

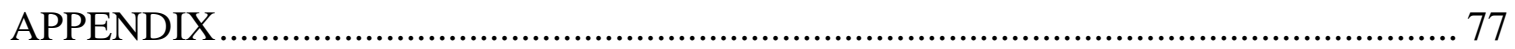




\section{LIST OF TABLES}

TABLE

PAGE

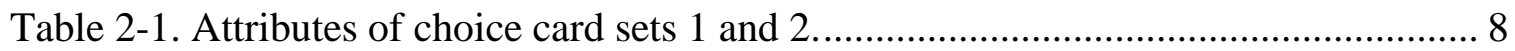

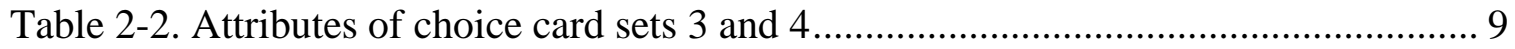

Table 2-3. Parameters of semivariogram models ............................................................ 29

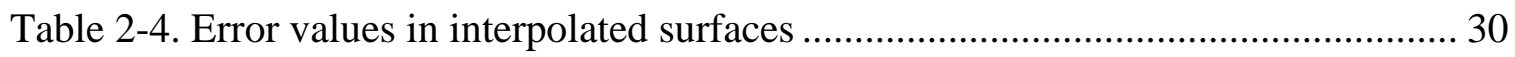

Table 3-1. Comparison of sociodemographic characteristics of survey respondents and census 2010 for the state of Florida ..................................................................... 43

Table 3-2. Climate change related questions and their scaling system......................... 49

Table 3-3. Description of explanatory variable with descriptive statistics ......................50

Table 3-4. Analyzing risk perception about climate change and its impacts to the functionality and sustainability of the ecosystem services provided by the Everglades .. 62

Table 3-5. Analyzing household risk perception on importance of the Everglades restoration considering sea level rise and salt water intrusion.

Table 3-6. Analyzing household preference for people's perception on restricting further development in low lying coastal areas 66 


\section{LIST OF FIGURES}

FIGURE

PAGE

Figure 2-1. Frequency of coincidence points............................................................. 12

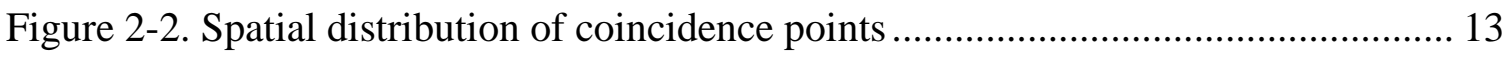

Figure 2-3. Quantile-Quantile plot of CC1 data before and after the transformation....... 14

Figure 2-4. Quantile-Quantile plot of CC2 data before and after the transformation....... 15

Figure 2-5. Quantile-Quantile plot of CC3 data before and after the transformation....... 15

Figure 2-6. Quantile-Quantile plot of CC4 data before and after the transformation....... 16

Figure 2-7. Tolerance Region binning prior to grid aggregation .................................. 19

Figure 2-8. Tolerance Region binning after grid aggregation .................................... 19

Figure 2-9. Example semivariogram surface with values and color............................. 20

Figure 2-10. Semivariogram surface map: choice card set 1 (Hydrological) .................. 21

Figure 2-11. Semivariogram surface map: choice card set 2 (Species) ........................ 21

Figure 2-12. Semivariogram surface map: choice card set 3 (Ecological) ...................... 22

Figure 2-13. Semivariogram surface map: choice card set 4 (Urban and Recreational) .. 22

Figure 2-14. Radial sector method for semivariogram (ESRI, 2001) ........................... 23

Figure 2-15. Semivariogram of card set 1 (Hydrological) major axis ............................ 24

Figure 2-16. Semivariogram of card set 1 (Hydrological) minor axis........................... 24

Figure 2-17. Semivariogram of card set 2 (Species) major axis .................................. 25

Figure 2-18. Semivariogram of card set 2 (Species) minor axis................................. 25

Figure 2-19. Semivariogram of card set 3 (Ecological) major axis .............................. 26

Figure 2-20. Semivariogram of card set 3 (Ecological) minor axis.............................. 26

Figure 2-21. Semivariogram of card set 4 (Urban and Recreational) major axis ............. 27

Figure 2-22. Semivariogram of card set 4 (Urban and recreational) minor axis ............. 27 
Figure 2-23. Prediction map and prediction standard error for Choice Card Set 1........ 32

Figure 2-24. Prediction map and prediction standard error for Choice Card Set 2 ......... 33

Figure 2-25. Prediction map and prediction standard error for Choice Card Set 3 ......... 34

Figure 2-26. Prediction map and prediction standard error for Choice Card Set 4 ......... 35

Figure 3-1. Spatial distribution of respondent's location in Florida............................. 47

Figure 3-2. Distance from shore vs elevation of respondents' residential location .......... 48

Figure 3-3. Response of RP question vs distance from shore and elevation ................... 53

Figure 3-4. Response of ER question vs distance from shore and elevation ................... 54

Figure 3-5. Response of RD question vs distance from shore and elevation .................. 54

Figure 3-6. Response of the three questions vs urban development.............................. 55

Figure 3-7. Response of the three questions vs urban water supply ............................ 55

Figure 3-8. Response of the three questions vs reduction of urban flood....................... 56

Figure 3-9. Response to Env Vs Eco question against the climate change questions ...... 57

Figure 3-10. Participation in recreational activities and risk perception ....................... 57

Figure 3-11. Participation in recreational activities and the Everglades restoration ........ 58

Figure 3-12. Participation in recreational activities and restriction on development ....... 58

Figure 3-13. Distance from shore vs elevation and respondents' agreement level ......... 60 


\section{ABBREVIATIONS AND ACRONYMS}

\begin{tabular}{|c|c|}
\hline $\mathrm{CC}$ & Climate Change \\
\hline CERP & The Comprehensive Everglades Restoration Plan \\
\hline $\mathrm{CS} \& \mathrm{~F}$ & The Central and South Florida Project \\
\hline EAA & Everglades Agricultural Area \\
\hline ENP & Everglades National Park \\
\hline ES & Ecosystem Services \\
\hline MAUT & Multi-Attribute Utility Theory \\
\hline OK & Ordinary Kriging \\
\hline RA & Recreational Activities \\
\hline SFWMD & South Florida Water Management District \\
\hline SFWSC & South Florida Water, Climate, Sustainability \\
\hline SP & Stated Preferences \\
\hline WASD & Miami Dade Water and Sewer Department \\
\hline WCA & Water Conservation Areas \\
\hline WTP & Willingness to Pay \\
\hline
\end{tabular}




\section{INTRODUCTION}

\subsection{Introduction}

The Florida Everglades, North America's largest subtropical wetland, has experienced anthropogenic perturbation since the last quarter of the $19^{\text {th }}$ century, when canals were built and peatlands drained for economic gain (Godfrey and Catton, 2011). Since then, the system has been exploited, drained, polluted, and changed from its natural condition to escalate and widen the services offered by it. The present state is a highly regulated system developed to buttress economic productivity and fulfill several regional demands. Though these management activities have come at considerable cost to the Everglades ecosystem, the system continues to offer services like hurricane protection and flood risk reduction, water storage and purification, habitat for numerous endemic or charismatic species, recreational opportunities, etc. The Comprehensive Everglades Restoration Plan (CERP), one of the world's largest restoration initiatives, aims to restore, protect and preserve the water resources of central and southern Florida (National Research Council, 2014). While the restoration program is built on a foundation of retrospective science backed by many years of sophisticated research on understanding the Everglades and similar ecosystems (Estenoz and Bush, 2015), the human dimension of restoration has not been studied adequately (Clarke and Dalrymple, 2003; Kranzer, 2002; National Research Council, 2014). Moreover, as CERP aims to restore the ecosystem without compromising the present services - which are spatially dependent - it is important to understand the spatial variability of residents' preferences or the heterogeneity of their opinions for successful implementation of the plan. 
Social dynamics of restoration in a multifaceted ecosystem like the Everglades is an intricate process. The system includes numerous services that demand compromising the functionality of the ecosystem. Moreover, the management complexity increases when it involves stakeholders with conflicting interests for those services. Understanding local preferences and being able to predict possible conflict, will assist decision makers as they design restoration strategies that align better with the social fabric. Disregarding spatial variation often aggregates outcomes and obscures local heterogeneity, ignoring regional outliers (Campbell et al., 2009). For instance, increased freshwater flow in the Everglades will not affect the estuarine and upland communities equally, and changes in fish habitat at Lake Okeechobee will not affect the entire population of South Florida in the same way. Considering this spatial dependency of ecosystem services of the Everglades, it is also important to measure the extent of spatial clustering effect, or spatial autocorrelation, of the attributes for robust decision making while assessing people's perceptions.

Milon et al. (1999) conducted a survey to elicit the public's willingness to pay for the Everglades restoration prior to the outset of the CERP. They used two choice alternative sets (comprising hydrologic and species attributes to exhibit relevant ecosystem services) and both sets indicated that the likelihood of support for restoration will depend on balancing restoration objectives with costs imposed on Floridians. The result suggested that the general public may oppose restoration if it imposes severe restriction on water use or involves excess (more than \$25) annual cost. While Milon et al. (1999) study provided a primary benchmark of the public's preference for the restoration, it did not include the entire state (only five counties were considered) and more importantly, spatial 
variability of preferences was not considered in the analysis. Moreover, after fifteen years of implementation of the CERP, more information is available now about the possible ramifications of the plan from a scientific as well as societal viewpoint. Seeteram (2014) conducted a more inclusive study than the previous one both in terms of spatial coverage and consideration of ES. She estimated people's Willingness to Pay (WTP) for different ES using response from the general public (Florida residents) as well as salt-water anglers. The Seeteram (2014) study provided new insight into people's WTP to avoid water use restriction and restore flow in the Water Conservation Areas of the Everglades. Although, the recent estimation of WTP will permit decision makers to better gauge the priorities of the general public, it will not reveal the range of preferences for the ES. Thus, a study that incorporates recent data as well as considering the spatial variability of perception can provide a more robust understanding of residents' preferences for the CERP.

With that in mind, the objectives of the present study are: (1) to assess the spatial variation of public preference for different ES offered by the Everglades and (2) to assess public perception of climate change impacts in the Everglades and impact mitigation.

The first part of the study includes interpolation of public opinion to estimate the level of preference (Seeteram, 2014). Geocoded discrete choice survey data of 949 responses were used for the interpolation. The work produced four different interpolation surfaces showing public preference for different sets of ES of the Everglades. The Ordinary Kriging method was applied to perform the interpolation. Four corresponding standard error maps were also produced to evaluate the accuracy of the interpolation. 
The second part of the study tried to model the relationship of general public's perception about climate change and different variables such as frequency of participation in recreational activity in the Everglades, their priorities on environmental protection and economic growth, and several pieces of sociodemographic information. Respondents were asked to state their level of agreement about the consequences of climate change to the Everglades, if they think more rigorous measures should be taken to restore the Everglades, and if development in low lying areas should be restricted. Their responses to these questions were correlated with different prediction variables to develop a reasonable inference derived from the survey data. 


\section{SPATIAL MAPPING of PUBLIC PREFERENCE for EVERGLADES RESTORATION}

\subsection{Ecosystem services and restoration of the Everglades}

Like many other ecosystems, the South Florida Everglades offers a variety of ecosystem services (ES). These ES include: hurricane protection and flood-risk reduction, water purification, habitat for several endangered species, and providing recreational opportunities. Some of these services can be evaluated by comparison to market prices (e.g., fish and timber production, carbon storage, etc.), however, for others (biodiversity and flood-risk reduction), the process is not straight-forward (McCormick et al., 2010). The Comprehensive Everglades Restoration Plan (CERP) aims to restore, protect, and preserve the water resources of central and southern Florida. With its gradual implementation, the plan would alter both the magnitude and direction of several ES provided by the system. From decision makers' perspective, a major stipulation is to understand how residents, directly or indirectly have benefited from ES and how they are going to respond during the estimated three decades of CERP implementation. Evaluation of perceived and/or acquired benefits will provide insights into the social acceptance of CERP. The evaluation of public preference may manifest in the development, modification, or avoidance of legislation related to the implementation of CERP and therefore has significant social and potentially legal ramifications.

While much research is focused on the science of Everglades restoration, little effort is dedicated to the socioeconomic dimensions of CERP (McCormick et al., 2010; Seeteram, 2014). The present study explored elements of people's preference for the ES 
provided by the Everglades and further elaborated the spatial variation, e.g., proximity to the Everglades, inherent in these preferences. Often, aggregated measurement of preferences obscures local heterogeneity and ignores regional outliers. Therefore, together with understanding collective preferences, it is also important to assess the existence of spatial deviations that might occur in any diverse, multifaceted population. Comprehensive insight about spatial heterogeneity not only helps understand preferences, it also enables decision makers to circumvent local conflicts that may interrupt regional harmony.

The primary motivations for this study are: (1) the significance of ES offered by the Everglades vary greatly depending on the geographic location of ES users (e.g., increased freshwater flow will not affect the estuarine and upland communities equally), (2) understanding this spatial pattern will facilitate robust decision making for ecosystem management as well as offer illustration of local preferences for different ESs (Berbel et al., 2010), (3) ESs often include non-market goods and services that are spatially arranged. By performing spatial analysis, it is possible to disaggregate the preferences for ES and identify underlying patterns and degrees of spatial dependency. The CERP aims to restore the Everglades via a sequential series of interventions. Those interventions may alter ES that benefit residents today. Understanding public preference for ESs and the spatial distribution of preference will enable decision makers to better incorporate stakeholder participation during implementation of the CERP. 


\subsection{The survey:}

In order to assess public preference for the restoration of the Everglades, a survey was conducted. The survey followed the discrete choice experiment methodology. The Qualtrics online server was used to host the survey and the invitation to participate in the survey was sent via email to the general public living in Florida. The contact information for potential participants from the general public was purchased from a licensed vendor (Seeteram, 2014). The survey questionnaire included four different sets of choice cards. Each set had 20 cards of varying levels of attributes. The first two sets of cards were designed to replicate the attributes of the Milon et al. (1999) study whereas card sets Three and Four had attributes that were not considered in that study but have significant implication due to the restoration of the Everglades. Table 2-1 provides a description of the attributes used to design the first two sets of choice cards and Table 2-2 includes attributes used in choice card sets Three and Four with a brief description of their relation to the restoration. A detailed description of the attributes is given by Seeteram (2014). The first choice card set (CC1) emphasized attributes related to hydrological aspects of the system, and the second choice card set (CC2) included attributes related to different ecosystem species populations. Both card sets presented two different scenarios that reflect the level change of related ES because of the implementation of the CERP. Respondents choose one scenario for each of the choice card sets that maximizes her/his utility (i.e., maximum output for that particular respondent) for the attributes of a corresponding card set. 
Table 2-1. Attributes of choice card sets 1 and 2.

\begin{tabular}{|c|c|c|}
\hline & Attribute & Description \\
\hline \multirow{5}{*}{ 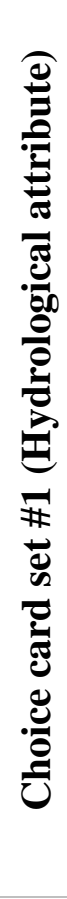 } & $\begin{array}{l}\text { Water stage in Lake } \\
\text { Okeechobee }\end{array}$ & $\begin{array}{l}\text { Restoration may alter the water stage at Lake } \\
\text { Okeechobee, which will affect ES such as } \\
\text { fish availability }\end{array}$ \\
\hline & $\begin{array}{l}\text { Water stage in the Water } \\
\text { Conservation Areas }\end{array}$ & $\begin{array}{l}\text { Change in water stage in the Water } \\
\text { Conservation Areas will affect the } \\
\text { downstream water and farmland availability }\end{array}$ \\
\hline & $\begin{array}{l}\text { Water stage at the Everglades } \\
\text { National Park }\end{array}$ & $\begin{array}{l}\text { Change in water stage in the Everglades } \\
\text { National Park will affect groundwater } \\
\text { recharge }\end{array}$ \\
\hline & $\begin{array}{l}\text { Reduction of Farmland } \\
\text { Acreage }\end{array}$ & $\begin{array}{l}\text { Increasing water level in the above three } \\
\text { components of the system will cause } \\
\text { reduction of farmland acreage. }\end{array}$ \\
\hline & $\begin{array}{l}\text { Restrictions on outdoor Water } \\
\text { Use }\end{array}$ & $\begin{array}{l}\text { More water in the system and increasing } \\
\text { demand for water will increase the outdoor } \\
\text { water use restriction }\end{array}$ \\
\hline \multirow{5}{*}{ 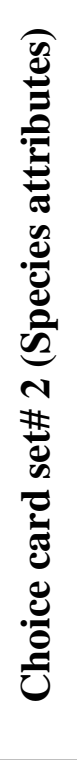 } & $\begin{array}{l}\text { Reduction of Wetland Species } \\
\text { population }\end{array}$ & $\begin{array}{l}\text { Reduction of water in the system will reduce } \\
\text { the wetland species population }\end{array}$ \\
\hline & $\begin{array}{l}\text { Reduction of Dryland Species } \\
\text { population }\end{array}$ & $\begin{array}{l}\text { Increased water in the system will reduce the } \\
\text { amount of dryland and thus dryland species } \\
\text { population }\end{array}$ \\
\hline & $\begin{array}{l}\text { Reduction of Florida Bay } \\
\text { Species population }\end{array}$ & $\begin{array}{l}\text { Nutrient-rich water from upstream can affect } \\
\text { the species population of Florida Bay }\end{array}$ \\
\hline & $\begin{array}{l}\text { Reduction of Farmland } \\
\text { Acreage }\end{array}$ & $\begin{array}{l}\text { Change in water level to protect species may } \\
\text { reduce farmland acreage }\end{array}$ \\
\hline & $\begin{array}{l}\text { Restrictions on outdoor Water } \\
\text { Use }\end{array}$ & $\begin{array}{l}\text { More water in the system and increasing } \\
\text { demand for water will increase outdoor water } \\
\text { use restriction }\end{array}$ \\
\hline
\end{tabular}


Table 2-2. Attributes of choice card sets 3 and 4

\begin{tabular}{|c|c|c|}
\hline & Attribute & Description \\
\hline \multirow{4}{*}{ 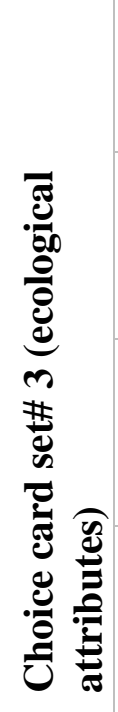 } & $\begin{array}{l}\text { Fish availability in Lake } \\
\text { Okeechobee }\end{array}$ & $\begin{array}{l}\text { Change of water level in the lake will affect } \\
\text { the productive littoral zone and affect the } \\
\text { fish availability }\end{array}$ \\
\hline & $\begin{array}{l}\text { Availability of agricultural } \\
\text { water }\end{array}$ & $\begin{array}{l}\text { Agricultural water demand is expected to } \\
\text { increase and this sector will encounter } \\
\text { tradeoffs with other uses of water }\end{array}$ \\
\hline & Coastal water quality & $\begin{array}{l}\text { Change in water discharge and nutrient } \\
\text { concentration will affect coastal water } \\
\text { quality }\end{array}$ \\
\hline & Freshwater quality & $\begin{array}{l}\text { Freshwater nutrient-impacted areas will be } \\
\text { affected by the change in nutrient } \\
\text { concentration of discharged water }\end{array}$ \\
\hline \multirow{6}{*}{ 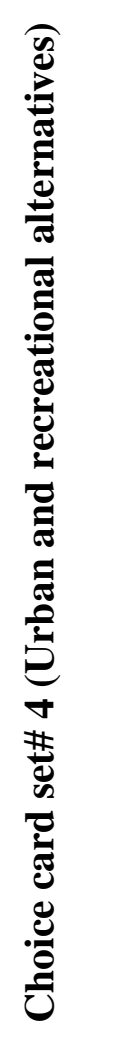 } & Inland Mangrove Expansion & $\begin{array}{l}\text { Due to increased salinity in nearshore areas, } \\
\text { the mangrove zone is expected to expand } \\
\text { inward }\end{array}$ \\
\hline & $\begin{array}{l}\text { Restrictions on Urban } \\
\text { Expansion }\end{array}$ & $\begin{array}{l}\text { Due to sea level rise, restriction on } \\
\text { development is expected in low-lying coasta } \\
\text { areas }\end{array}$ \\
\hline & Water Quality of Estuaries & $\begin{array}{l}\text { Increased nutrient-rich water flow will affect } \\
\text { water quality in the estuaries }\end{array}$ \\
\hline & Municipal Water Supply & $\begin{array}{l}\text { Municipal water demand is expected to } \\
\text { increase and this sector will encounter } \\
\text { tradeoffs with other uses of water }\end{array}$ \\
\hline & $\begin{array}{l}\text { Recreation in Everglades } \\
\text { National Park }\end{array}$ & $\begin{array}{l}\text { Access to recreational activities in the ENP } \\
\text { will be affected due to change in water level } \\
\text { in different components of the system }\end{array}$ \\
\hline & Urban Flood Risk & $\begin{array}{l}\text { Due to high water level in the system, there } \\
\text { will be limited provision to divert flood } \\
\text { water which will increase urban flood risk }\end{array}$ \\
\hline
\end{tabular}


Similarly, choice card set 3 (CC3) included attributes related to ecological services (fish availability and water quality at different locations) offered by the Everglades. The choice card set 4 (CC4) included different urban and recreational ES that residents can access. Both CC3 and CC4 had three different scenarios from which respondents picked one that provides the highest level of utility. Table 2.2 lists the attributes of both CC 3 and CC4.

The survey also asked 6 questions about socio-demographic information, recreational activities, and perception on climate change. It also included four illustrative videos to familiarize respondents with the intricate interconnection between different ES and impact on one ES due to change in another. Card set CC1 (hydrological) and CC2 (species) had two levels of scenarios with associated costs from which respondents choose one. while card set CC3 (ecological) and $\mathrm{CC} 4$ (urban and recreational) had three scenarios to choose from.

\subsection{The Data:}

The survey data were collected using the Qualtrics panel and were cleaned by discarding incomplete responses. Along with the responses for the questions and selection of the choice cards, the data also included respondents' geographic information. A total of 949 responses were considered for this study that had geolocation within the state boundary of Florida and completed the entire survey. However, before we use the spatial data for making any statistical inference, we need to understand the strengths and limitations of the data. The subsection below discusses some main features of the dataset. 


\subsubsection{Understanding the spatial data:}

The online survey was conducted by FIU Qualtrics. The dataset comes with Longitude and Latitude information for each respondent. Unless a respondent used the Qualtrics Offline App on a GPS-enabled device, the Latitude and Longitude information is an approximation determined by comparing the participant's IP address to a location database. Since the geolocation services relies on a number of databases to approximate the location, the results are not accurate locations of respondents in most of the cases (Qualtrics, 2005). Moreover, Qualtrics uses geographic centers (on a two-dimensional plane, the centroid or gravitational center is considered as the geographic center) to estimate a respondent's location if the longitude and latitude information are unavailable. Both these generalizations (use of geolocation database for IP location and considering geographic center) have introduced coincidence of respondents' locations. A total of 949 responses were considered after removing obvious outliers from the original dataset. However, only 413 entries of the dataset have unique locations and of those 413, only 198 have a single respondent. This means that more than $79 \%$ of the responses have their location matching with at least one other respondent. This can go as high as 23 co-located respondents or coincidence points in the same location. Figure. 2.1 shows the frequency of the coincidence points of respondents' locations. 


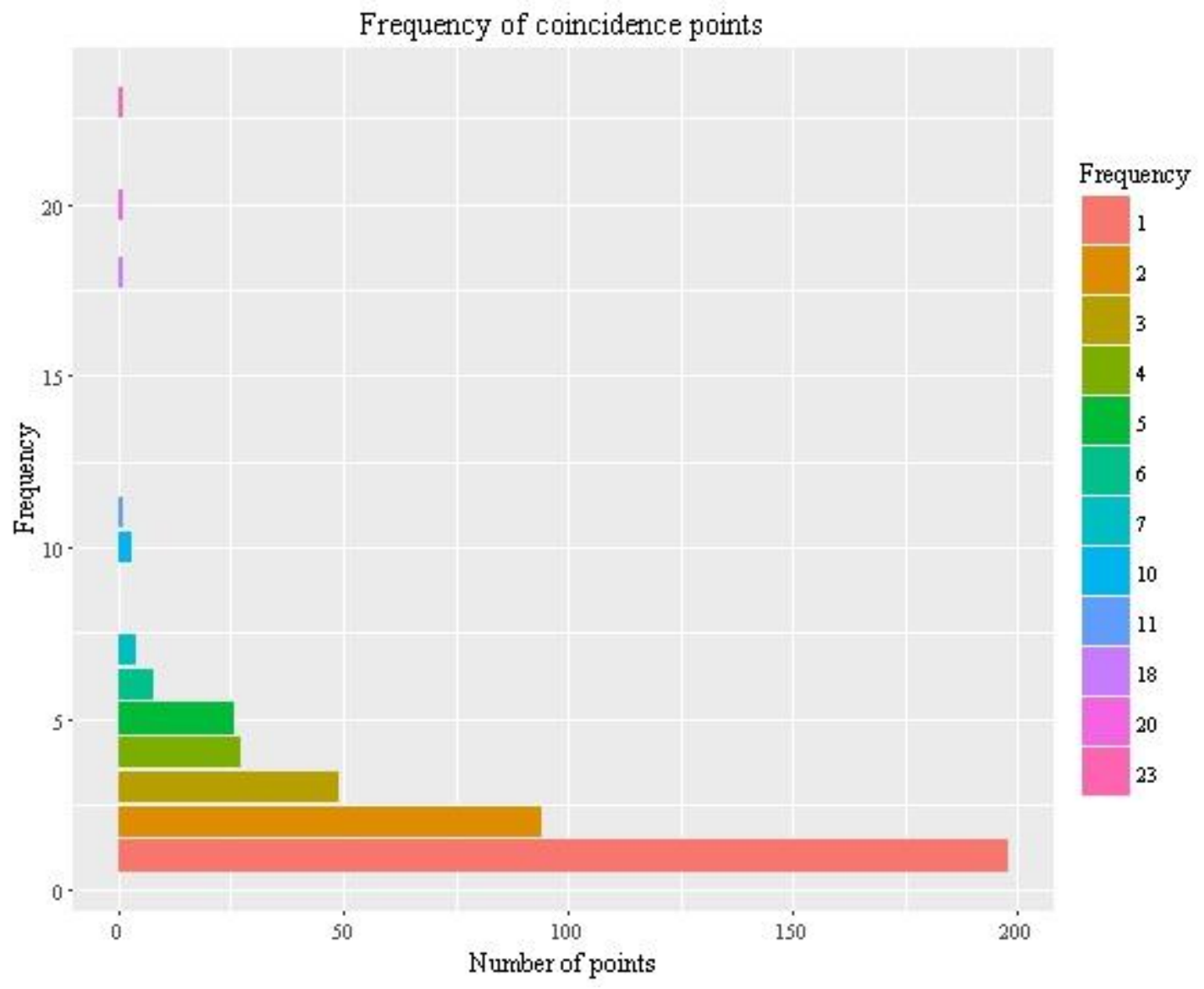

Figure 2-1. Frequency of coincidence points

Note: The $\mathrm{Y}$ axis of the figure shows the frequency of occurrence or number of responses from the same location and the $\mathrm{X}$ axis shows number of points (or unique locations) for each frequency values. For instance, the bottom-most bar $(Y=1, X=198)$ indicates there were 198 unique points from where only one respondent participated and the top-most $\operatorname{bar}(Y=23, X=1)$ indicates there was one point (location) from where 23 respondents replied.

This coincidence issue is important to keep in mind as it may change the response variable value at each coincidence point when any spatial interpolation technique is applied to the dataset. For instance, if we have three different responses from the same location (which has an expected value of 0.05 in this case) and we want to estimate public preference for surrounding area using a surface interpolation method, the mean of 
those three values (levels of preference are coded using numeric values) should be used for that. Not only does this transformation change the preference of respondents (by taking the average), but it also converts the categorical data into a continuous scale. The spatial position of the dataset displaying the variation of frequency of responses are plotted in Figure 2-2.

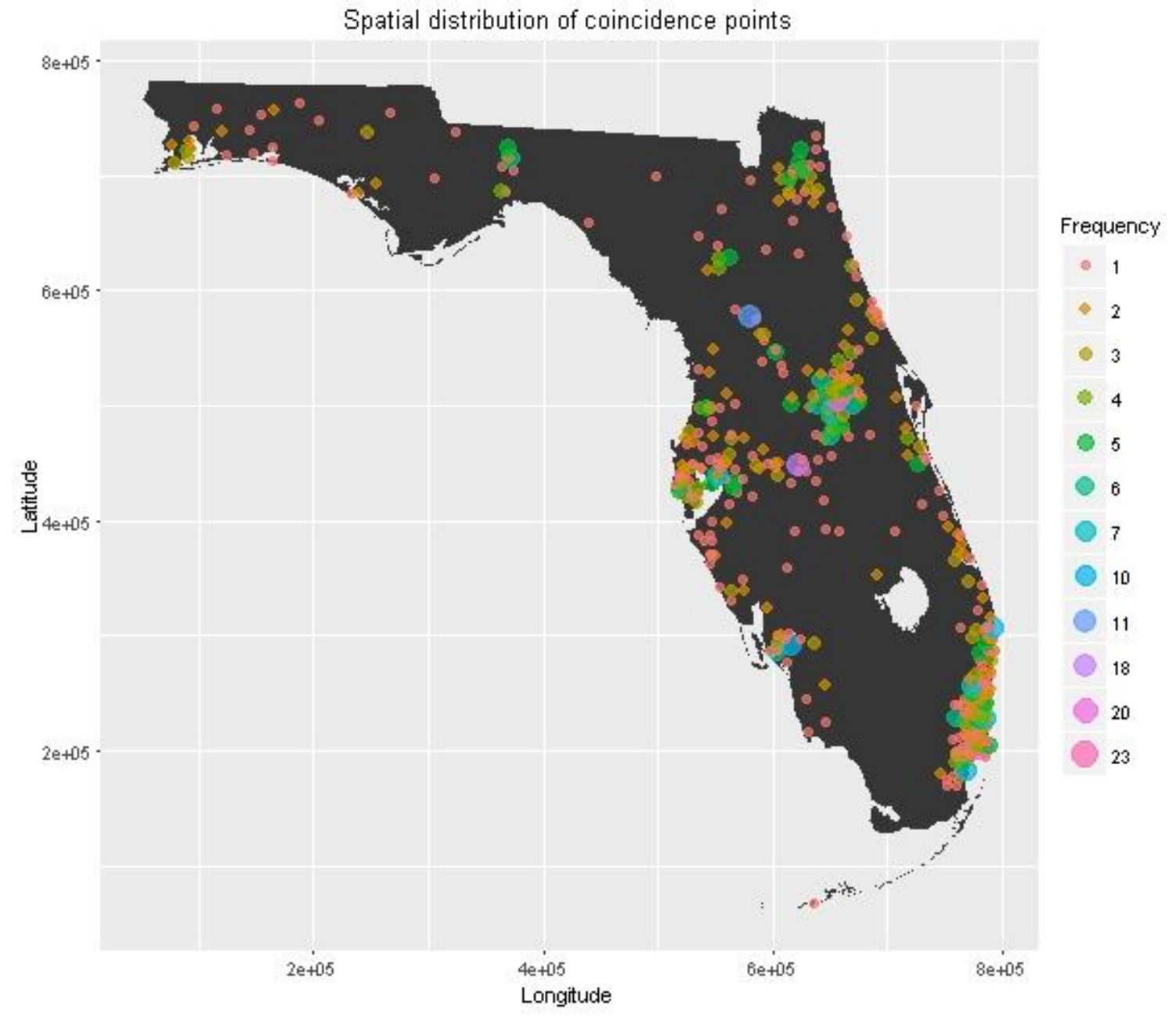

Figure 2-2. Spatial distribution of coincidence points

Note: The frequency of co-located responses is shown using the size and color of points. 
The comparisons of quantile-quantile plots of the dataset for each of the choice card selection variables are shown below. Figure 2.3, Figure 2.4, Figure 2.5 and Figure 2.6 show the data of $\mathrm{CC} 1, \mathrm{CC} 2, \mathrm{CC} 3$, and CC4 respectively. The left column shows the Q-Q plot before transformation for each of the choice cards and the right column shows the data after the transformation. The selection of restoration scenarios was coded as 1 and 2 for card sets One and Two and as 1,2, and 3 for card sets Three and Four. [Map linear unit: meter, Geographic Coordinate System: GCS_North_American_1983_HARN, Datum: D_North_American_1983_HARN]

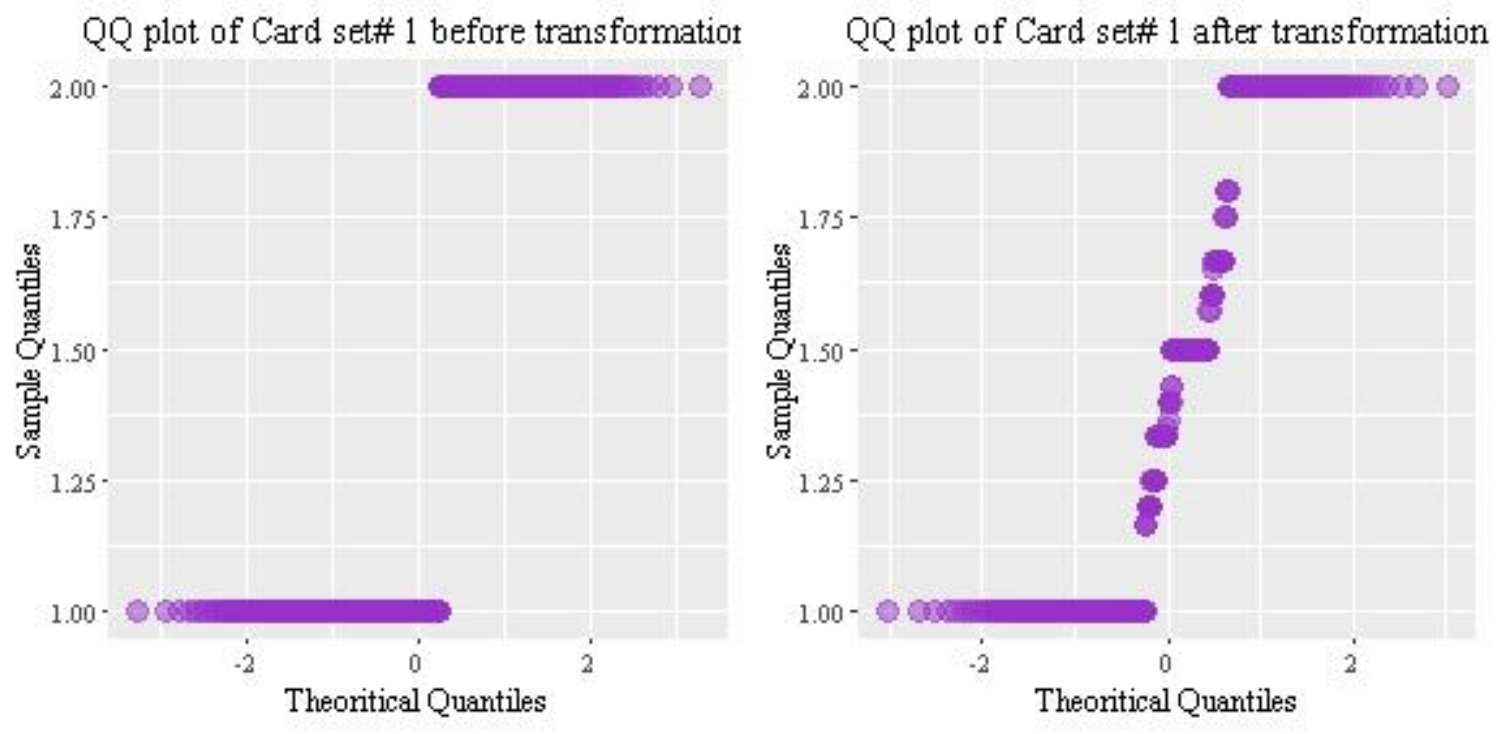

Figure 2-3. Quantile-Quantile plot of CC1 data before and after the transformation 

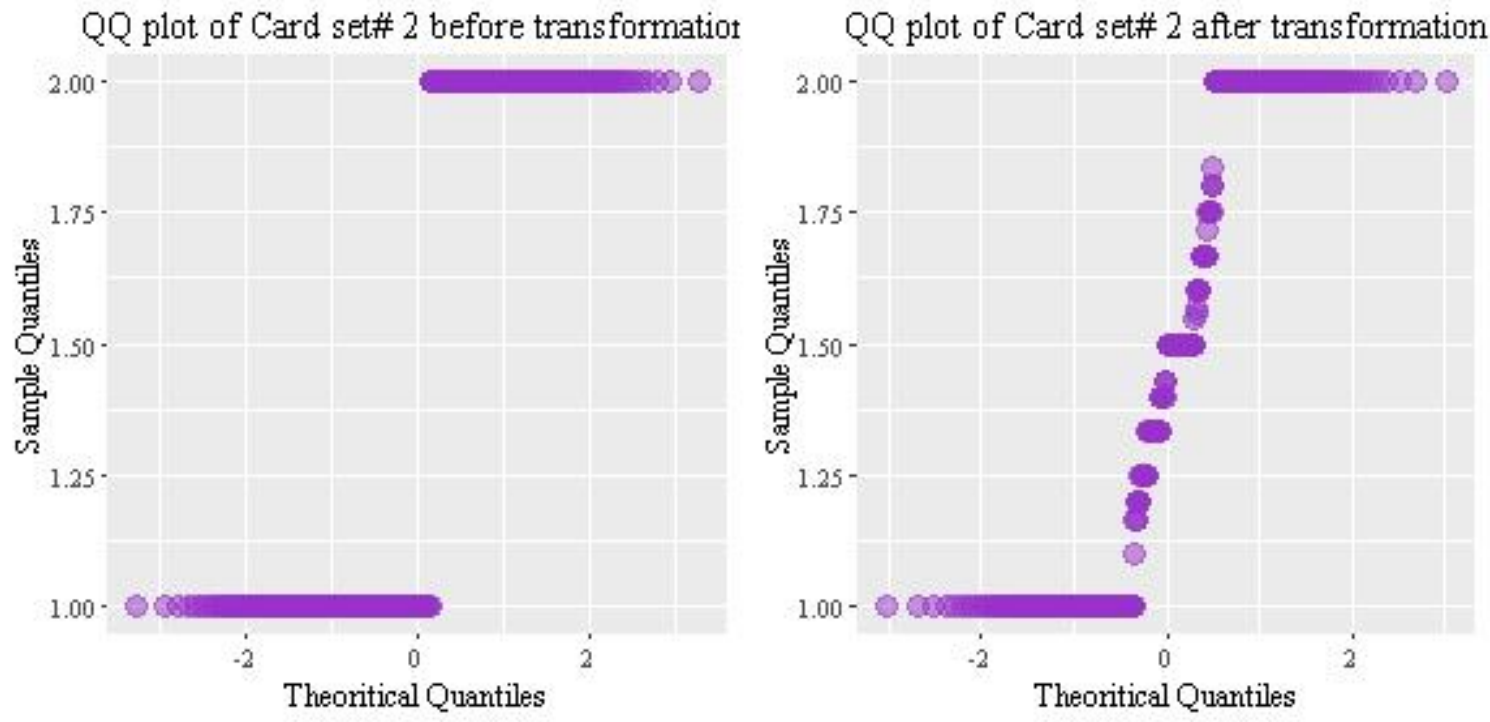

Figure 2-4. Quantile-Quantile plot of CC2 data before and after the transformation

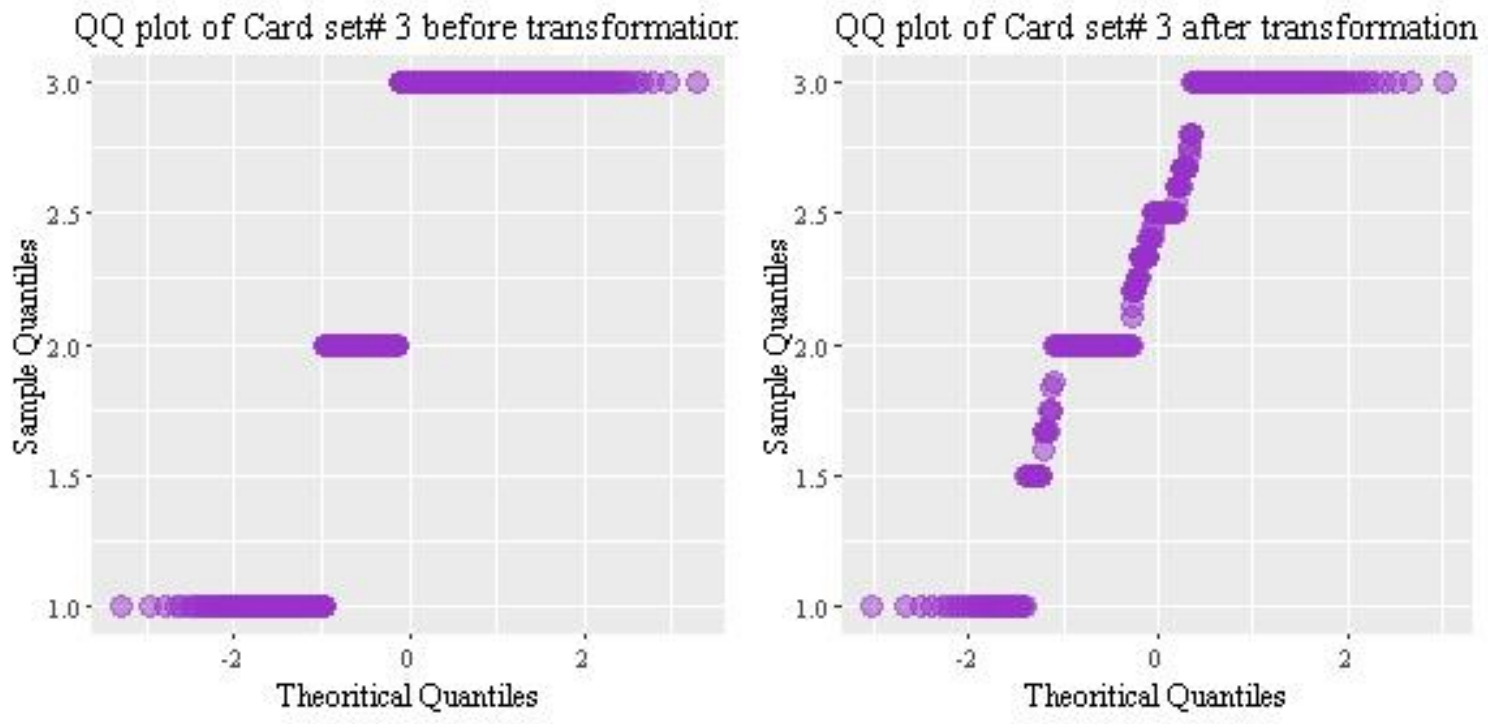

Figure 2-5. Quantile-Quantile plot of CC3 data before and after the transformation 

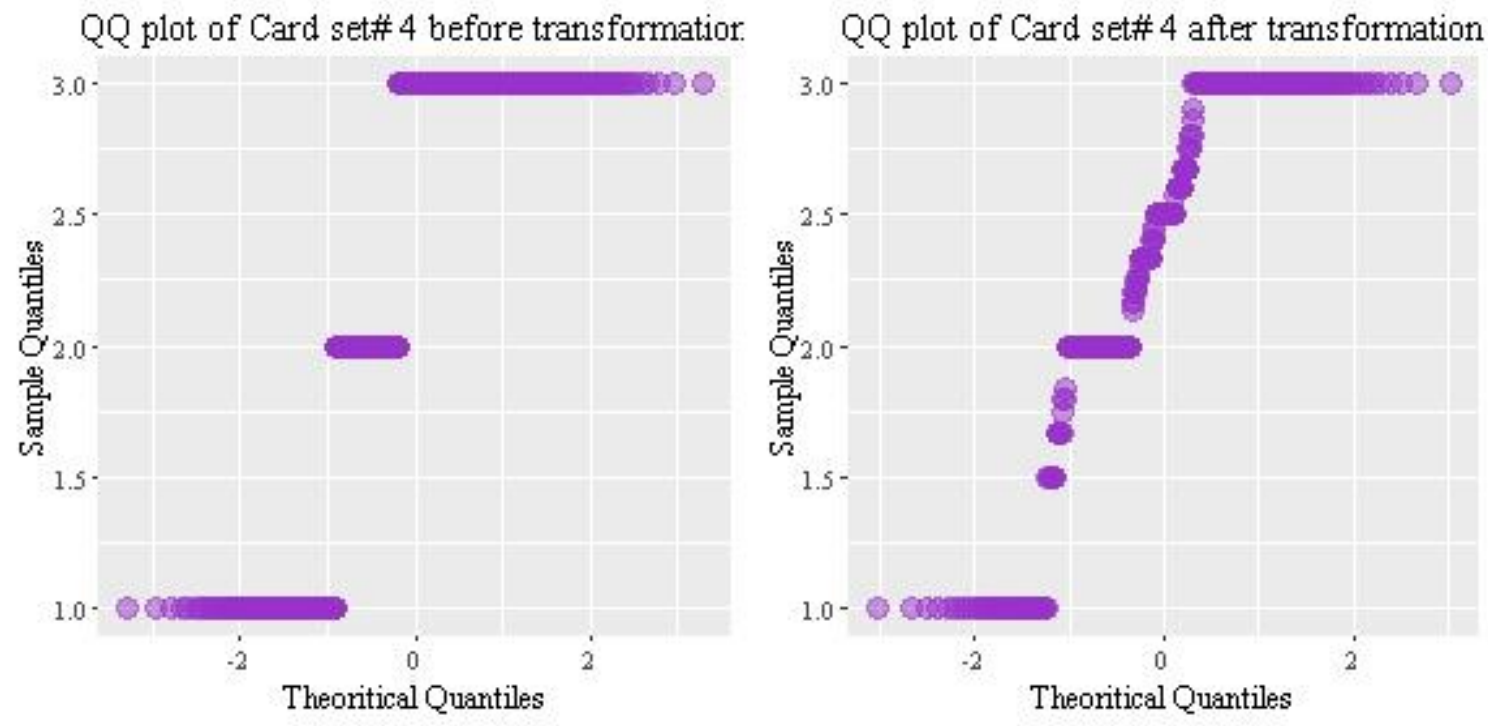

Figure 2-6. Quantile-Quantile plot of CC4 data before and after the transformation

\subsection{Spatial interpolation of public's preference for different Ecosystem Services}

A probabilistic interpolation method, Ordinary Kriging, was applied to the data set to estimate the public's preference for different sets of ES. Kriging entails optimal interpolation using statistical relationships against observed values of surrounding data points. Unlike deterministic methods such as the IDW (Inverse Distance Weighting) or spline interpolation, Kriging can also provide a measure of certainty of the prediction.

The first step of applying any Kriging method is to establish a semivariogram function for the empirical data. The semivariogram functions quantify the assumption that things nearby tend to be more similar than things that are farther apart (ESRI, 2016). The concept of semivariogram and fitting a representative model depends on one of the implications of Tobler's First Law of geography which states "Everything is related to 
everything else, but near things are more related than distant things." (Tobler, 1970). As a result of spatial autocorrelation, it is possible to capture a reasonably accurate description of attributes with a few well-placed samples.

\subsubsection{Semivariogram}

The semivariogram is a function of the distance and direction separating two locations (the lag) that quantifies the spatial dependence in the data (Krivoruchko, 2012). A semivariogram is constructed by calculating half the average squared difference of the empirical values of all the pairs of measurements at locations separated by a given distance (and possibly direction). The semivariogram is plotted on the y axis against the separation distance. The semivariogram can be defined by the following equation 2-1:

$$
\gamma\left(s_{i}, s_{j}\right)=\frac{1}{2} \operatorname{var}\left(Z\left(s_{i}\right)-Z\left(s_{j}\right)\right)
$$

Where, $\mathrm{s}_{\mathrm{i}}$ and $\mathrm{s}_{\mathrm{j}}$ are two different locations and $\mathrm{Z}\left(\mathrm{s}_{\mathrm{i}}\right)$ and $\mathrm{Z}\left(\mathrm{s}_{\mathrm{j}}\right)$ are corresponding measured values at those locations. According to Tobler's law, the difference between $\mathrm{Z}(\mathrm{si})$ and $\mathrm{Z}(\mathrm{sj})$ should be small if $\mathrm{s}_{\mathrm{i}}$ and $\mathrm{s}_{\mathrm{j}}$ are close.

In order to provide some averaging of potentially noisy differences, instead of taking all the points into consideration for the semivariogram, nearby points are generally grouped together into a bin or range of spatial lags. Parameters that determines the shape of a semivariogram model are the sill, range, nugget, and the directions, expressed as the major and minor ranges of spatial autocorrelation. A nugget effect can be attributed to measurement errors or spatial sources of variation at distances smaller than the sampling interval or both (ESRI, 2016). It is observed as the y-axis intercept of the semivariogram 
model. The sill is the y value of the semivariogram model where it levels out (often equivalent to the regular variance of the data set), and the range is the $\mathrm{x}$ value (lag) where the model reaches the sill. To account for anisotropy (where the semivariogram model reaches the sill more rapidly in some directions than others), a direction is used that defines the angle of the major axis of the range ellipse and the major and minor ranges are the lengths of the major and minor axis. The following section discusses anisotropy in the study data.

\subsubsection{Accounting for anisotropy}

Anisotropy is the property of a dataset that demonstrates different autocorrelation or spatial dependency in different directions (ESRI, 2001). As discussed by Isaaks and Srivastava (1961), a variogram surface map is an useful tool for determining the presence and direction of anisotropy. In ESRI ArcGIS Desktop the variogram surface map is produced by employs a binning approach based on rectangular tolerance regions, distributed uniformly on a grid (ESRI, 2001). For each observation point, a grid is generated by placing the point at the center (Figure 2-7) and all the other points are plotted depending on their distance and direction from the central point. Then those points are binned together based on which grid they fall into. The transformation is shown in the two figures below using a set of randomly generated numbers $(\mathrm{N}=500)$. The red dot shows the observation point under consideration and the blue dots are all other observation points. First, all other observation points (blue) are plotted in respect to their distance and direction from the red point. Then, the blue points are binned depending on their location in the grid (Figure 2-8). 


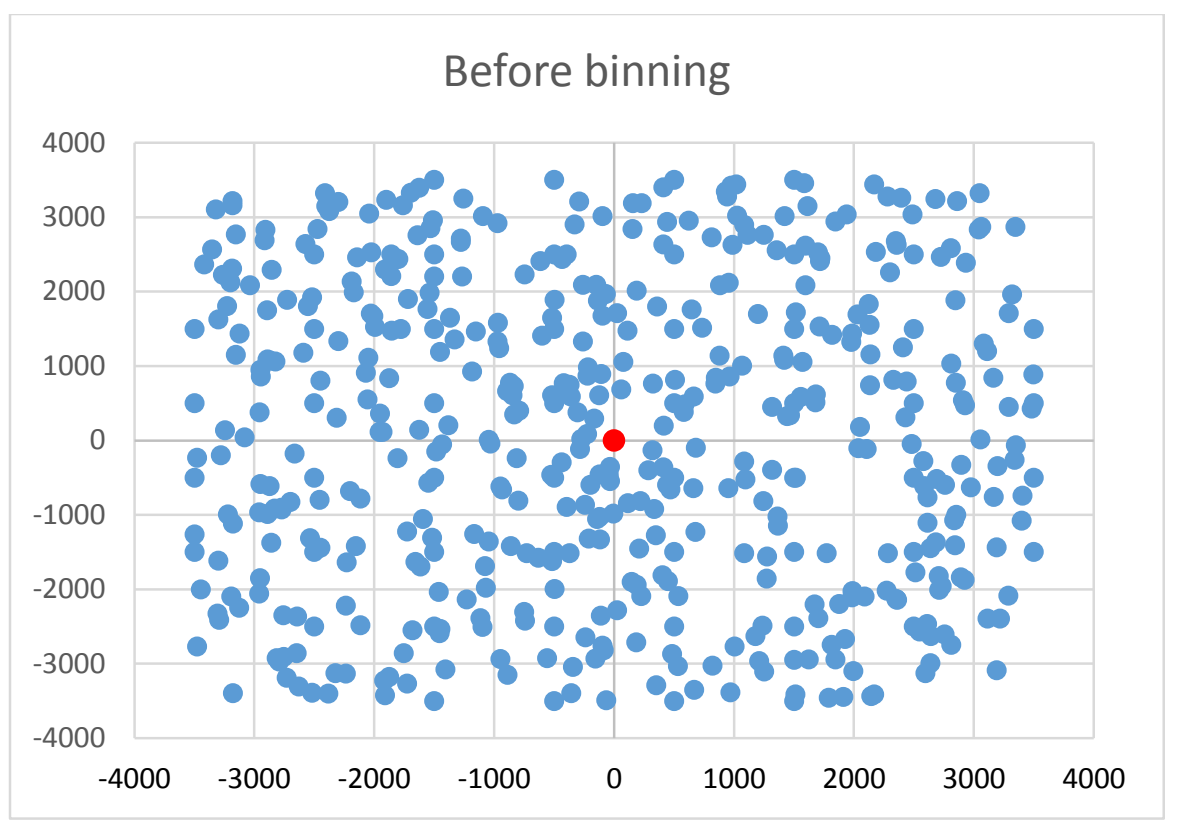

Figure 2-7. Tolerance Region binning prior to grid aggregation

\begin{tabular}{|c|c|c|c|c|c|c|c|c|}
\hline \multicolumn{9}{|c|}{ After binning } \\
\hline $\begin{array}{r}4000 \\
3000\end{array}$ & - & - & - & - & - & - & - & • \\
\hline \multirow{2}{*}{2000} & • & - & • & - & - & • & - & • \\
\hline & - & - & - & - & - & - & - & $\bullet$ \\
\hline 1000 & - & - & - & - & - & - & - & - \\
\hline 0 & - & - & • & - & - & - & - & $\bullet$ \\
\hline-1000 & - & - & - & - & - & - & - & $\bullet$ \\
\hline-2000 & - & - & - & - & - & - & - & - \\
\hline-3000 & • & - & - & - & • & - & - & • \\
\hline $\begin{array}{r}-4000 \\
-4\end{array}$ & & & & & & & & 4000 \\
\hline
\end{tabular}

Figure 2-8. Tolerance Region binning after grid aggregation 
After determining the points and their matching grids, half of the squared differences $(\gamma)$ of the observed values $\mathrm{Z}(\mathrm{s})$ are averaged. Then, these averaged values are assigned to the corresponding grid. This allows preservation of the spatial orientation. Figure 2-9 below shows an example using a data set of uniformly increasing values with increment of lag distance. Color sheds are used to indicate variation of averaged values for each grid.

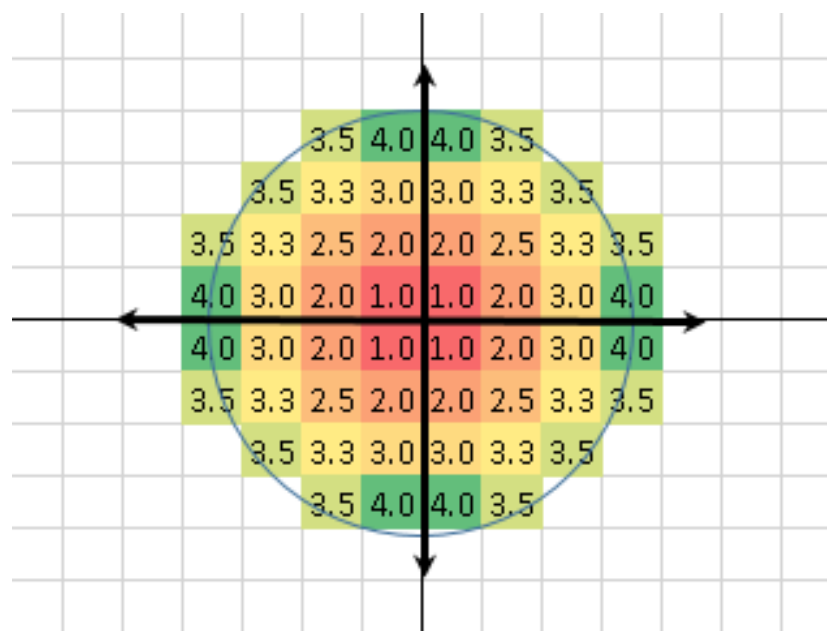

Figure 2-9. Example semivariogram surface with values and color.

Once the entire surface is generated, the presence and direction of anisotropy can be detected from the distribution of the averaged $\gamma$ values. If the spatial autocorrelation is the same in all directions, the color would change equally in all directions. But if the autocorrelation varies for different directions, the change in color would form an ellipsoidal shape. The semivariogram maps for the choice card sets data are presented in the four figures below. 


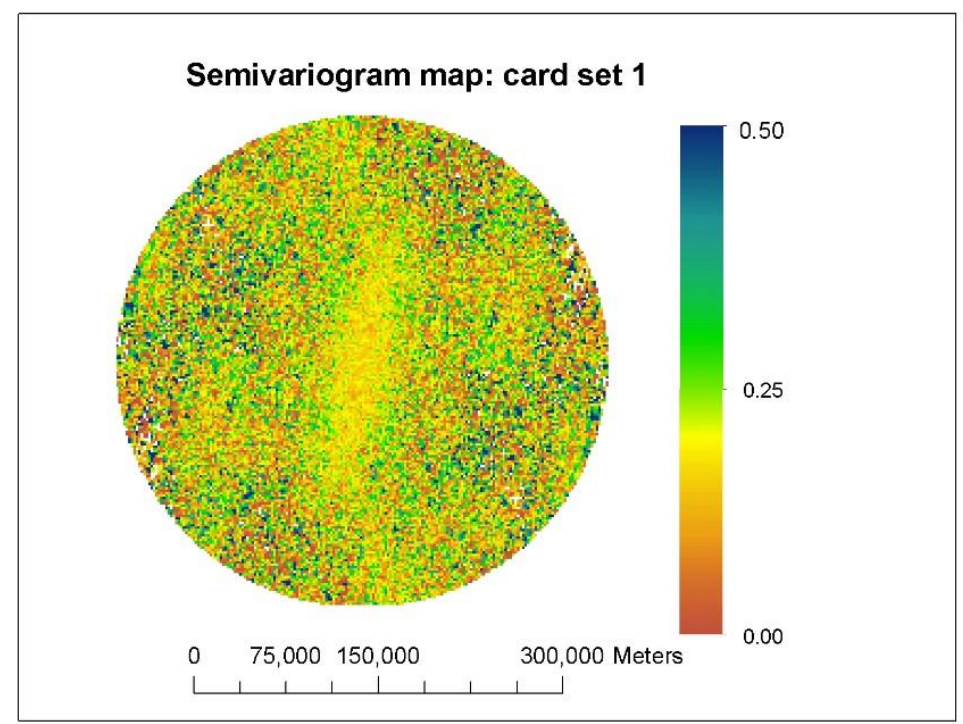

Figure 2-10. Semivariogram surface map: choice card set 1 (Hydrological)

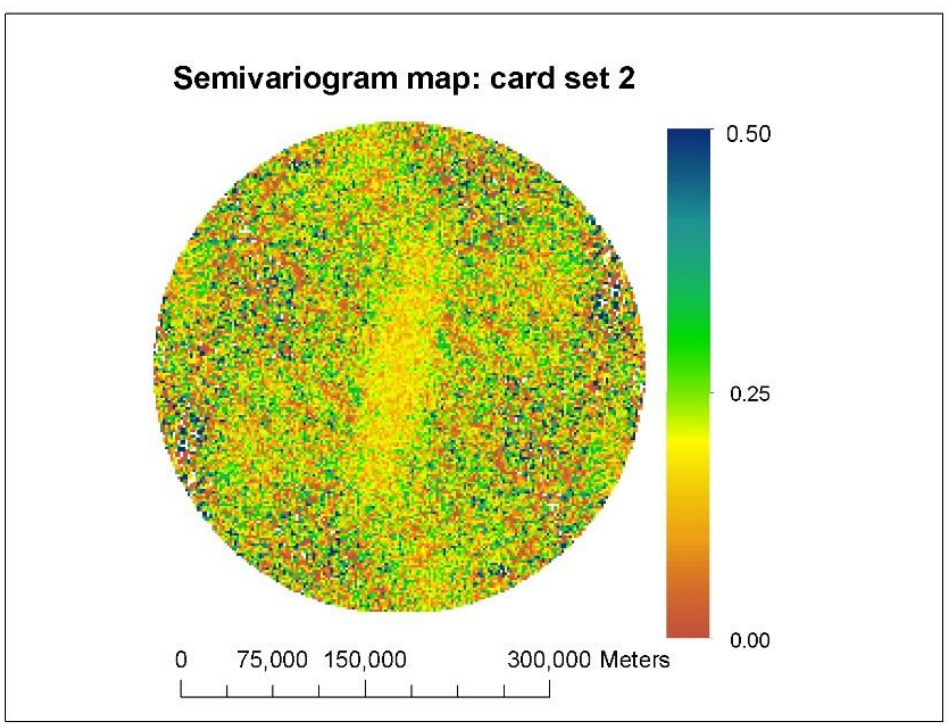

Figure 2-11. Semivariogram surface map: choice card set 2 (Species) 


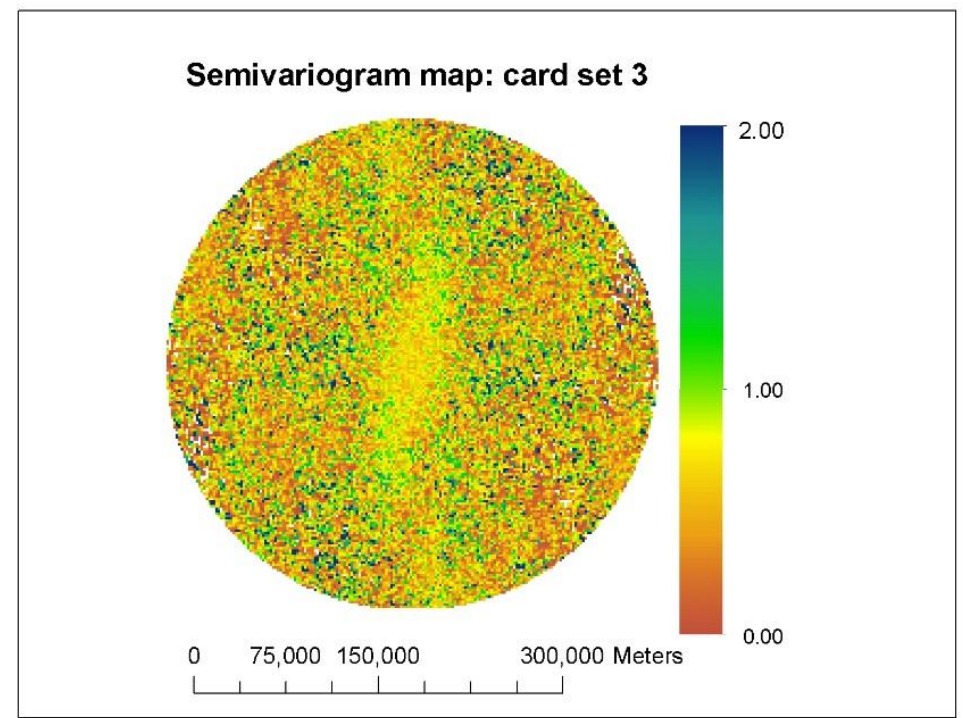

Figure 2-12. Semivariogram surface map: choice card set 3 (Ecological)

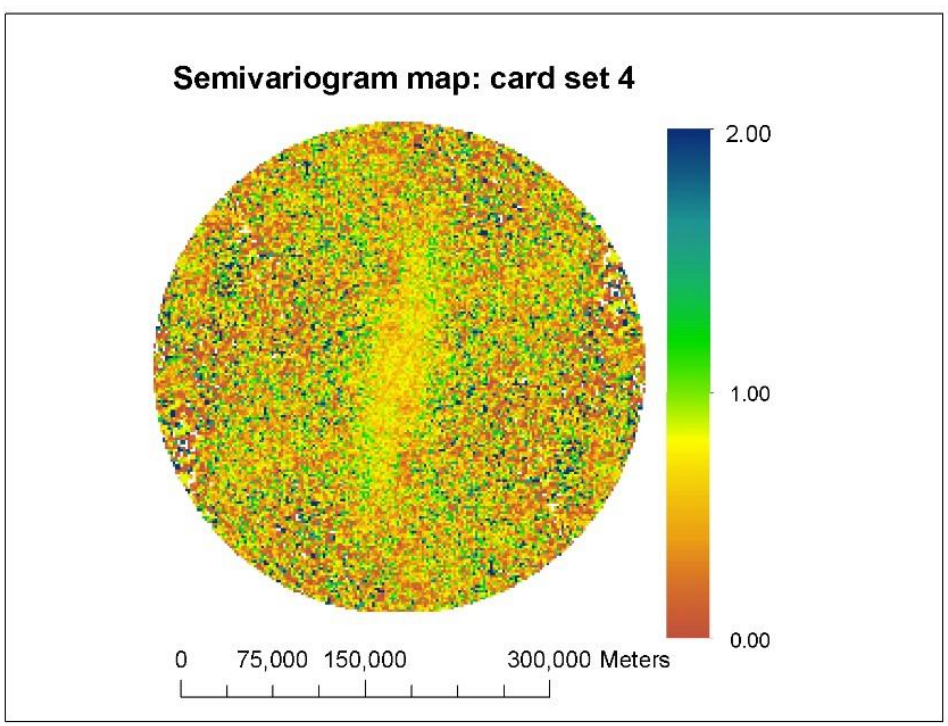

Figure 2-13. Semivariogram surface map: choice card set 4 (Urban and Recreational) 
We can see from all the four figures (Figure 2-10 to Figure 2-13) above that the change in color for the grids were not uniform. There is a conspicuous trend slightly inclined from the $\mathrm{Y}$ axis (in the northeast direction). In order to further investigate the presence and extent of anisotropy we developed semivariograms along the major and minor axis of the search ellipses.

While developing semivariograms, the ESRI ArcGIS Desktop calculates both binned and averaged values. The binned values (red dots) are generated employing the tolerance regions grids method discussed above. The averaged values (blue crosses) are produced using the radial sector method (ESRI, 2001).

For the radial sector method, the binning is computed on a tolerance region $T\left(h_{k}\right)$. Where $h_{k}$ is the distance between the point $s_{i}$ and center of a radial bin (Figure 1-8). Similar to the grid method, all the points that belong to one sector are averaged to obtain the $\gamma$ value for that sector.

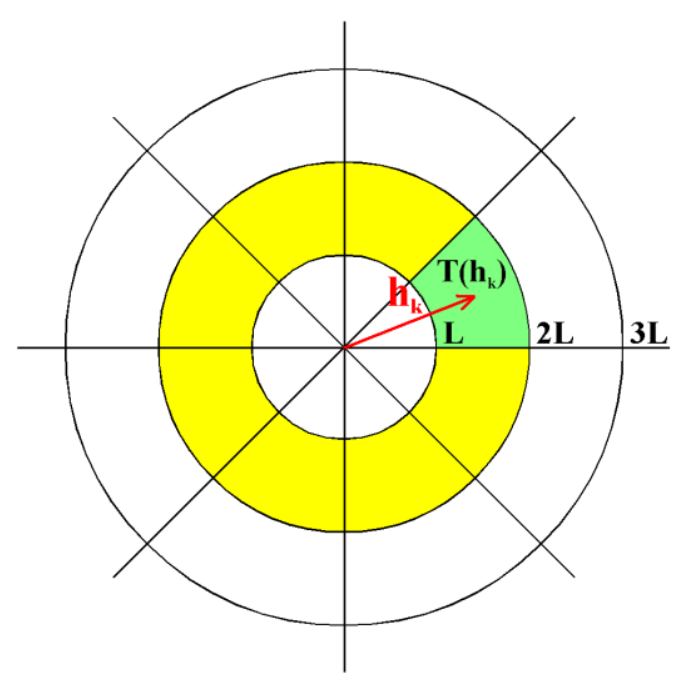

Figure 2-14. Radial sector method for semivariogram (ESRI, 2001) 
The semivariograms for the four choice card sets are presented below.

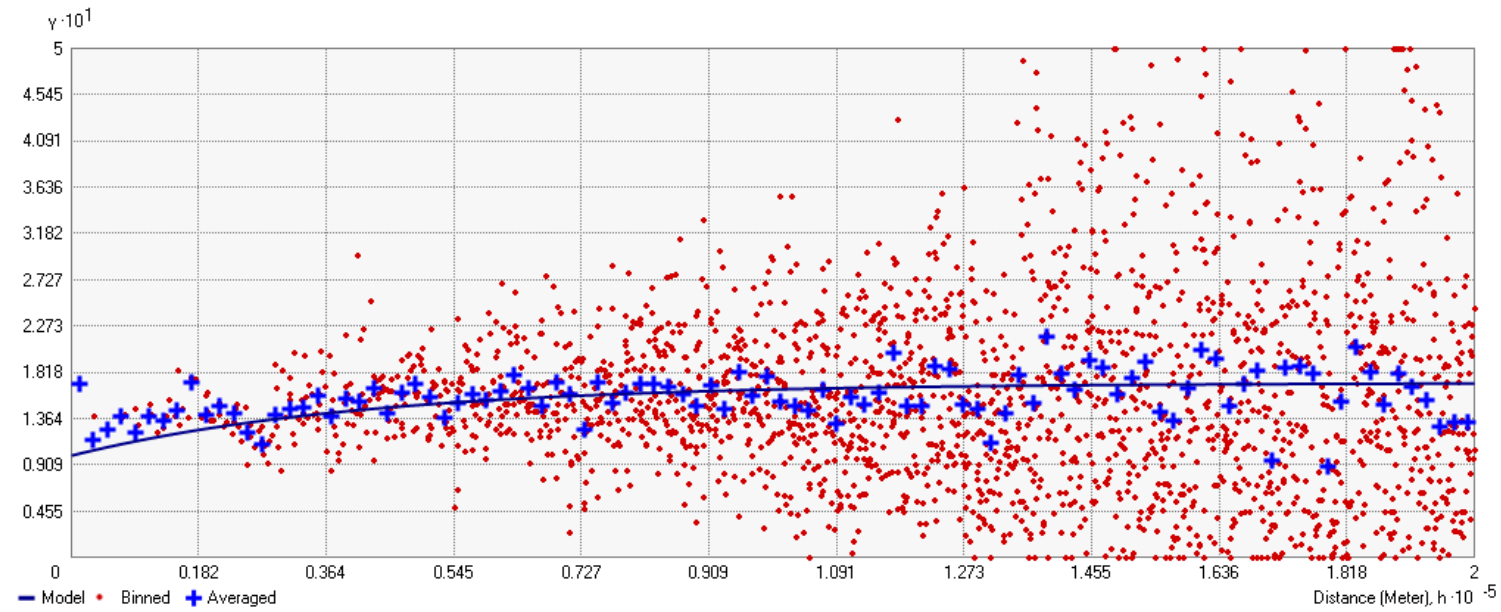

Figure 2-15. Semivariogram of card set 1 (Hydrological) major axis

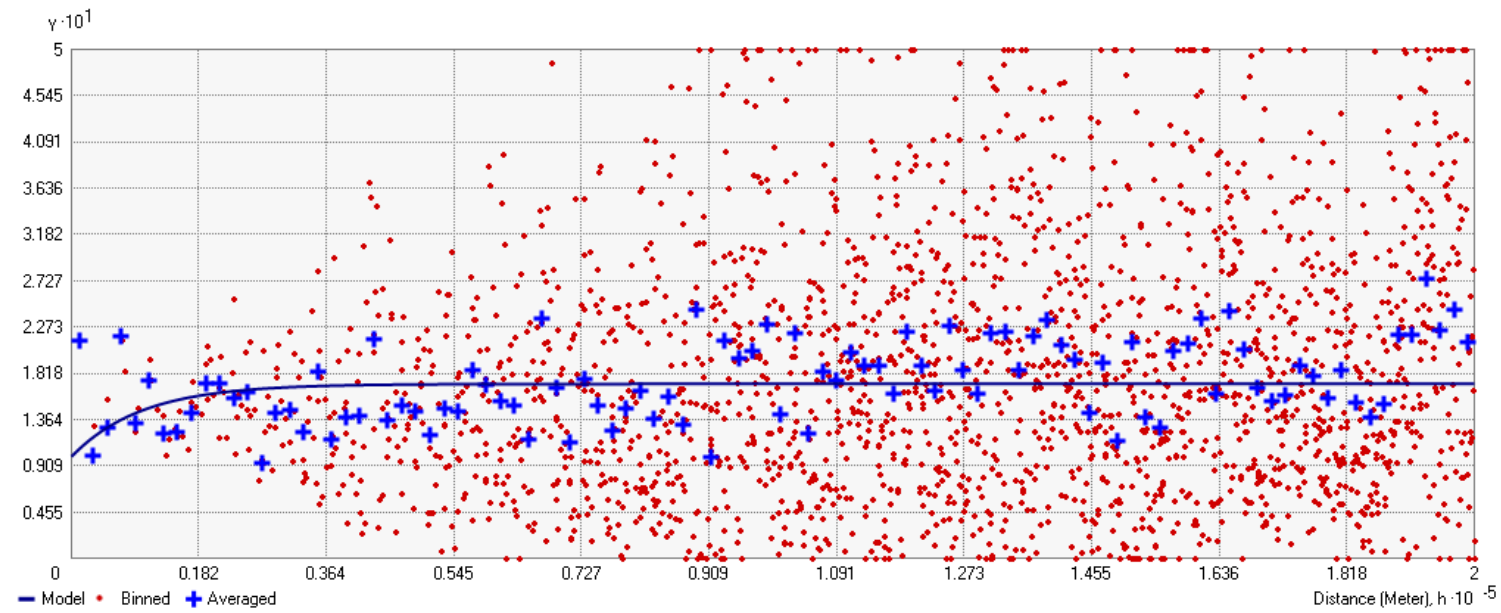

Figure 2-16. Semivariogram of card set 1 (Hydrological) minor axis 


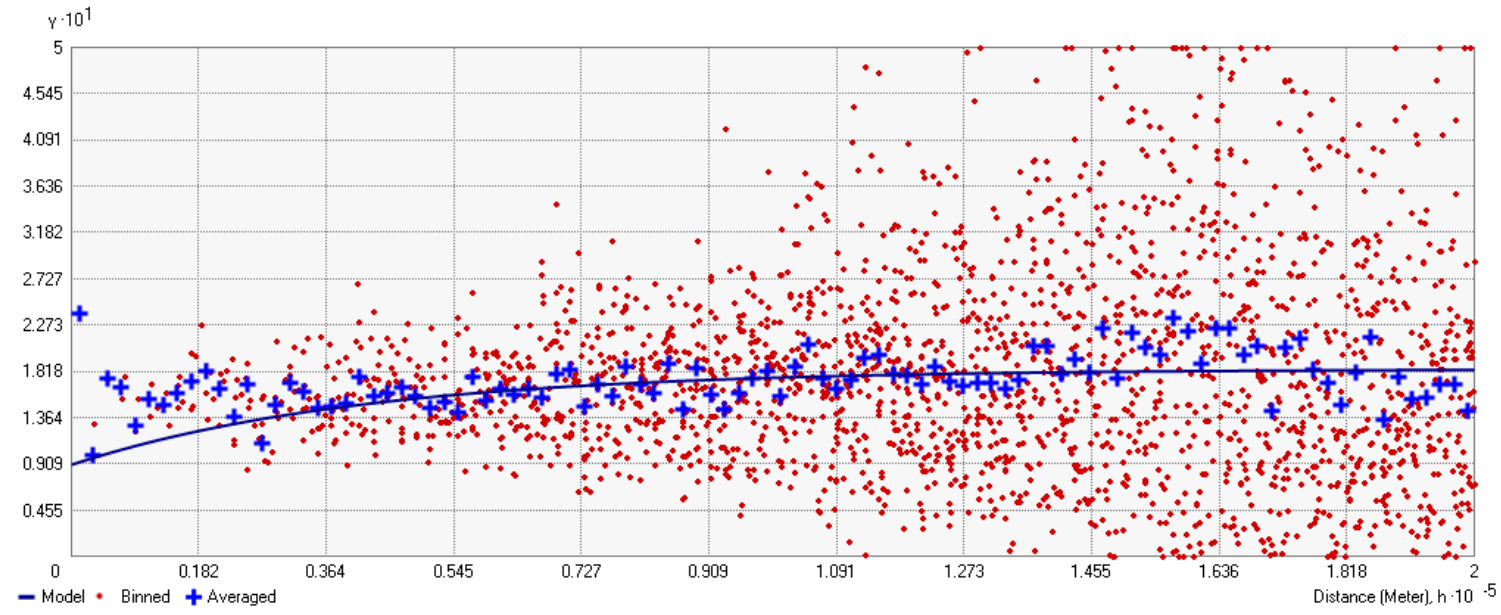

Figure 2-17. Semivariogram of card set 2 (Species) major axis

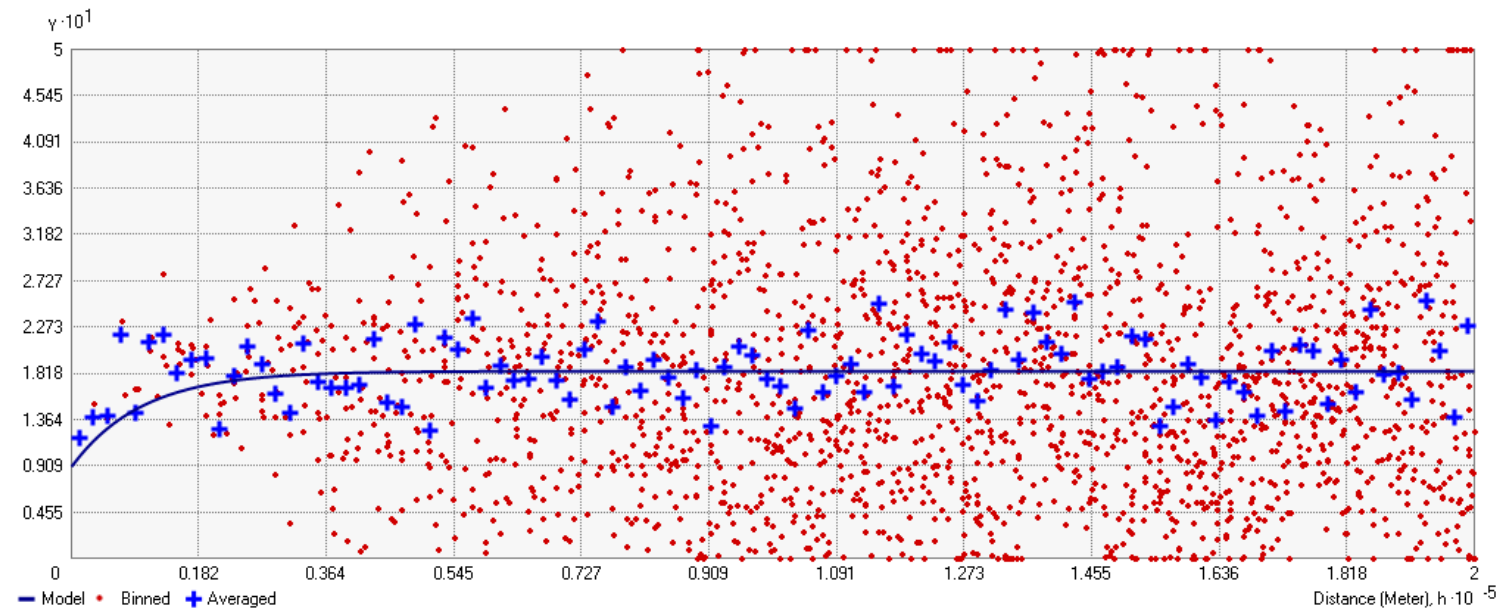

Figure 2-18. Semivariogram of card set 2 (Species) minor axis 


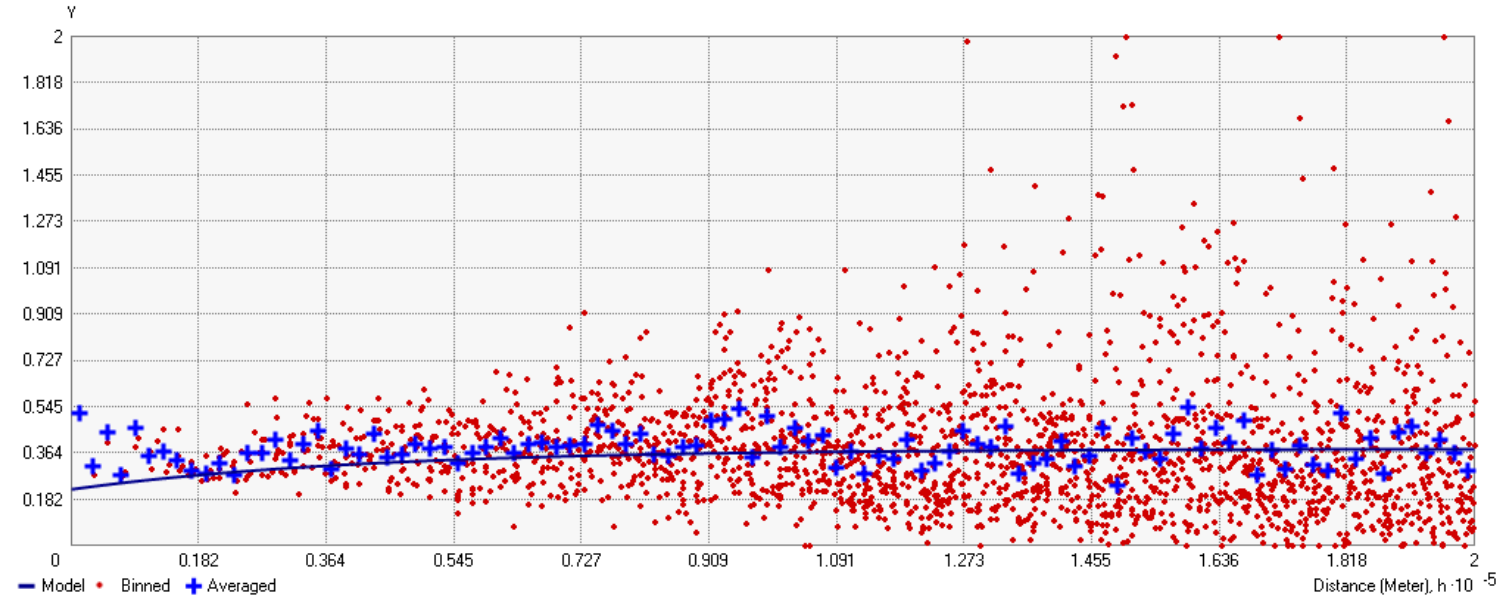

Figure 2-19. Semivariogram of card set 3 (Ecological) major axis

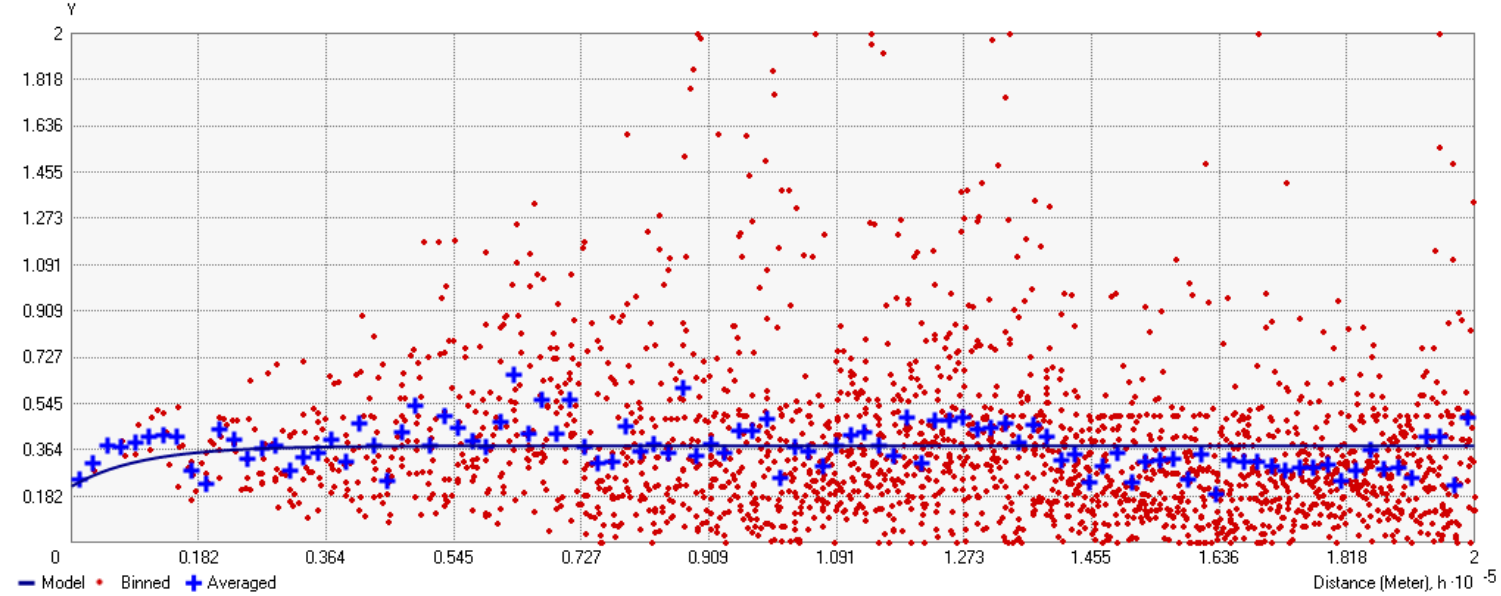

Figure 2-20. Semivariogram of card set 3 (Ecological) minor axis 


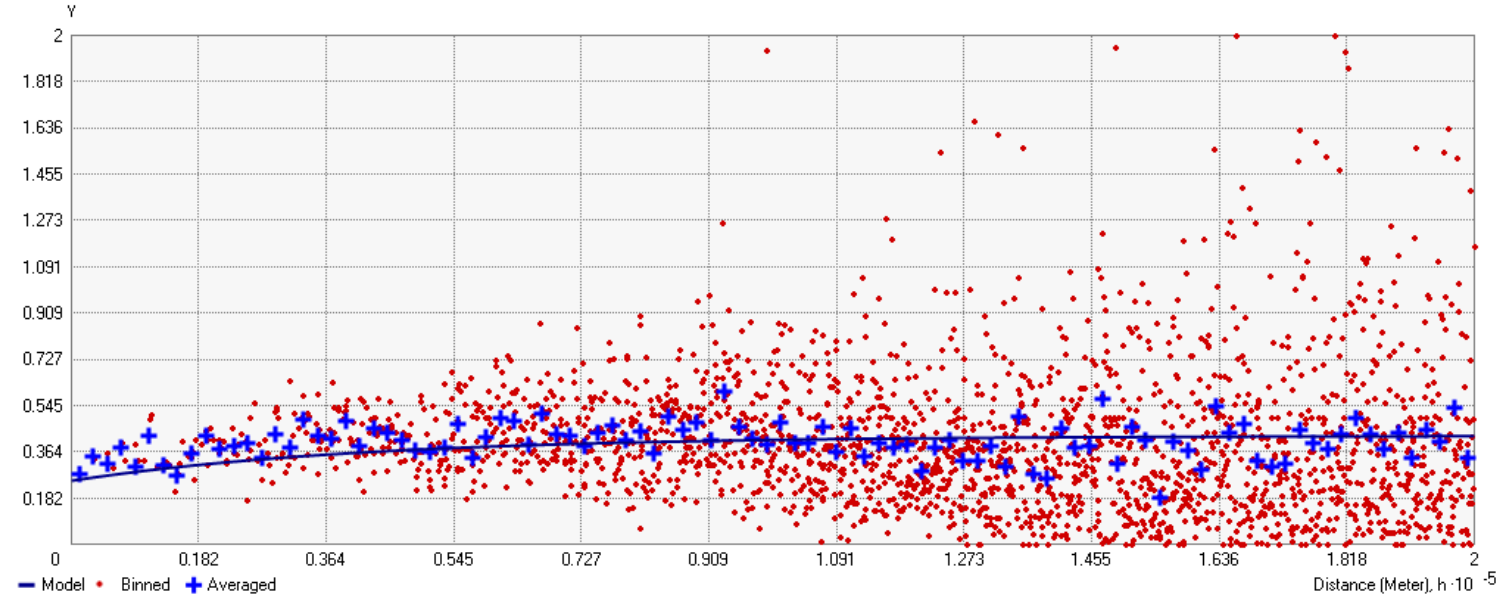

Figure 2-21. Semivariogram of card set 4 (Urban and Recreational) major axis

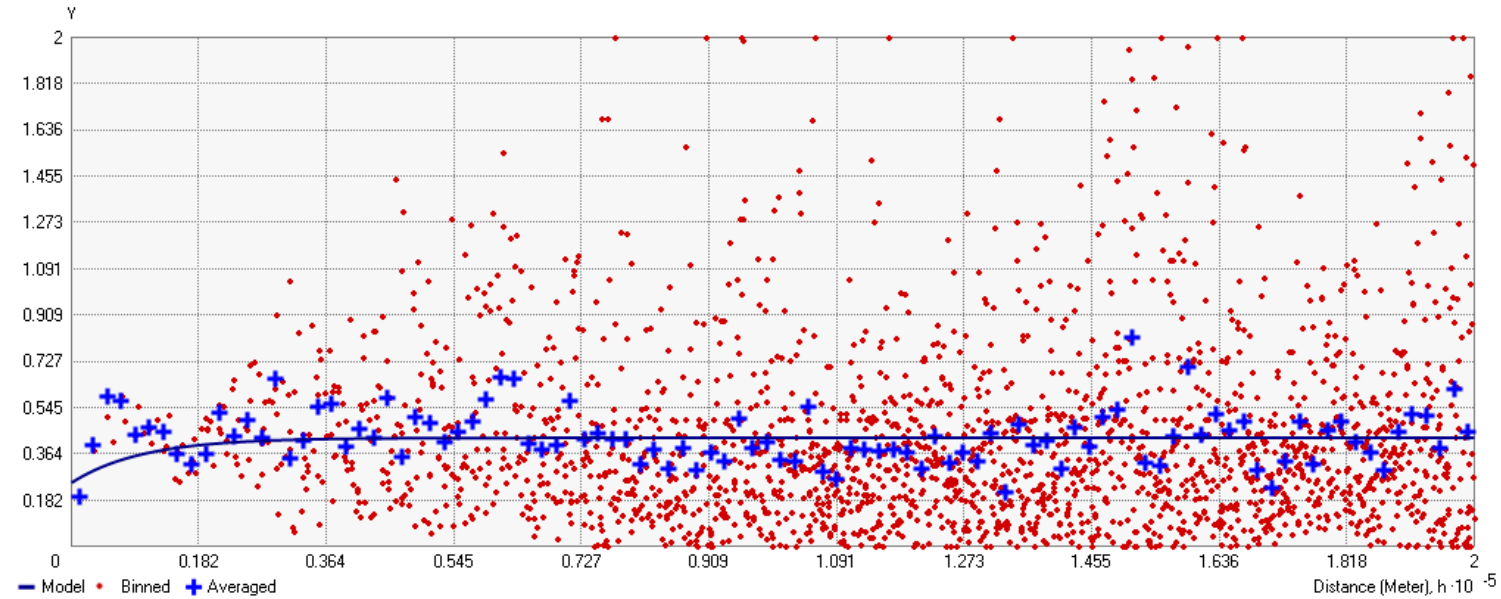

Figure 2-22. Semivariogram of card set 4 (Urban and recreational) minor axis

From the above eight semivariograms it is clear that in all cases the data along the major axis were less distorted and both the binned and averaged points were close to the semivariogram models. It implies that the data for all four card sets were anisotropic and the major axis of the ellipse was approximately along $\mathrm{N} 9^{\circ} \mathrm{E}$ and the minor axis was $\mathrm{E} 99^{\circ}$ $\mathrm{S}$ from the $\mathrm{Y}$ axis. 


\subsubsection{Ordinary Kriging}

Kriging uses the theoretical model developed by fitting the semivariogram to the data to estimate the values at spatial points where no measurement data are available. The Ordinary Kriging method considers that the mean is unknown and is calculated from the local neighborhood of each estimation point. The following equation (2-2) is used to calculate an estimated value of the spatial variable at location $\boldsymbol{x}$ :

$Z^{*}(\boldsymbol{x})=m(\boldsymbol{x})+\sum_{\alpha=1}^{n(x)} \lambda_{\alpha}(\boldsymbol{x})\left[Z\left(\boldsymbol{x}_{\alpha}\right)-m(\boldsymbol{x})\right]$

Where, $Z^{*}(\boldsymbol{x})$ is the unknown value of the location of interest, $m(\boldsymbol{x})$ is the local mean, $\lambda_{a}(\boldsymbol{x})$ is the weight calculated from the semivariogram model and $Z\left(\boldsymbol{x}_{a}\right)$ is the known value at a nearby location.

By changing the nugget and partial sill value (nugget - total sill) the models were adjusted to approximately fit the averaged (blue cross) points in the semivariogram. In all cases the exponential function was selected to fit the points. The variogram calculation and theoretical model identification were done in ArcGIS Desktop 10.3. The parameters for the models are given in Table 2.3 below. As show in Table 2-3, Model 4 has the highest partial sill and Model 1 has the lowest, which indicates the variance of the corresponding datasets. 
Table 2-3. Parameters of semivariogram models

\begin{tabular}{|c|c|c|c|c|c|}
\hline & Parameter & Card set 1 & Card set 2 & Card set 3 & Card set 4 \\
\hline \multirow{10}{*}{ 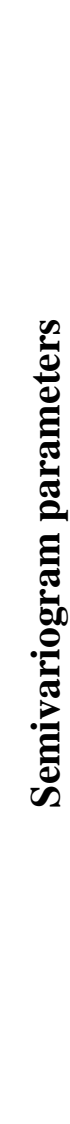 } & $\begin{array}{l}\text { Lag size } \\
\text { (meter) }\end{array}$ & 2000 & 2000 & 2000 & 2000 \\
\hline & Number of lags & 100 & 100 & 100 & 100 \\
\hline & Model nugget & Enabled & Enabled & Enabled & Enabled \\
\hline & Nugget value & 0.1 & 0.09 & 0.22 & 0.25 \\
\hline & Partial sill & 0.071 & 0.094 & 0.159 & 0.176 \\
\hline & $\begin{array}{l}\text { Semivariogram } \\
\text { model type }\end{array}$ & Exponential & Exponential & Exponential & Exponential \\
\hline & Anisotropy & True & True & True & True \\
\hline & $\begin{array}{l}\text { Major range } \\
\text { (meter) }\end{array}$ & 125000 & 125000 & 125000 & 125000 \\
\hline & $\begin{array}{l}\text { Minor range } \\
\text { (meter) }\end{array}$ & 30000 & 30000 & 30000 & 30000 \\
\hline & $\begin{array}{l}\text { Direction of } \\
\text { the major range }\end{array}$ & $\mathrm{N} 14^{\circ} \mathrm{E}$ & $\mathrm{N} 10^{\circ} \mathrm{E}$ & $\mathrm{N} 11^{\circ} \mathrm{E}$ & $\mathrm{N} 16^{\circ} \mathrm{E}$ \\
\hline \multirow{6}{*}{ 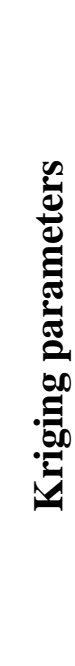 } & $\begin{array}{l}\text { Neighborhood } \\
\text { type }\end{array}$ & Standard & Standard & Standard & Standard \\
\hline & $\begin{array}{l}\text { Maximum } \\
\text { neighbor }\end{array}$ & 20 & 20 & 20 & 20 \\
\hline & $\begin{array}{l}\text { Minimum } \\
\text { neighbor }\end{array}$ & 3 & 3 & 3 & 3 \\
\hline & Sector type & 8 sectors & 8 sectors & 8 sectors & 8 sectors \\
\hline & Search angle & $\mathrm{N} 13.54^{\circ} \mathrm{E}$ & $\mathrm{N} 10^{\circ} \mathrm{E}$ & $\mathrm{N} 11^{\circ} \mathrm{E}$ & $\mathrm{N} 9^{\circ} \mathrm{E}$ \\
\hline & Major semiaxis & 125000 & 125000 & 125000 & 125000 \\
\hline
\end{tabular}




\begin{tabular}{|l|l|l|l|l|l|}
\hline & Parameter & Card set 1 & Card set 2 & Card set 3 & Card set 4 \\
\hline & Minor semiaxis & 30000 & 30000 & 30000 & 30000 \\
\hline
\end{tabular}

In addition to the prediction map, a standard error map was also produced for each interpolation. These maps show the accuracy of prediction based on standard error of the interpolated values. The Table 2-4 presents Root-Mean Square (indicates model's accuracy predicting the measured values. The smaller this error, the better the prediction), Root-Mean Square Standardized (values close to one indicate better prediction, values greater than one indicate underestimation and values less than one indicate overestimation), and Average Standard Error of estimation (this is the mean of the standardized errors and better prediction should yield values close to 0 .).

Table 2-4. Error values in interpolated surfaces

\begin{tabular}{|l|l|l|l|l|}
\hline Parameter & Card set 1 & Card set 2 & Card set 3 & Card set 4 \\
\hline Root-Mean-Square & 0.426 & 0.436 & 0.627 & 0.681 \\
\hline $\begin{array}{l}\text { Root-Mean-Square } \\
\text { Standardized }\end{array}$ & 1.139 & 1.178 & 1.137 & 1.157 \\
\hline $\begin{array}{l}\text { Average Standard } \\
\text { Error }\end{array}$ & 0.373 & 0.371 & 0.554 & 0.590 \\
\hline
\end{tabular}




\subsection{Generation of preference map}

Four Public preference maps were produced from the variogram models presented above. To address anisotropy of the data, a search radius of major axis 10,000 meter and minor axis 5,000 meter was selected with a maximum number of neighbors of 20 and minimum of 3 was set to produce the surface.

For the first choice card that includes attributes such as Water stage in Lake Okeechobee, Water Conservation Areas, and the Everglades National Park, Reduction of Farmland Acreage, Restrictions on outdoor Water Use, and corresponding monetary implications of these changes, the prediction map is shown below. The prediction standard error map is also included to understand the validity of the prediction. Prediction standard error shows the accuracy of the estimation by producing a surface with same extent as the prediction. 


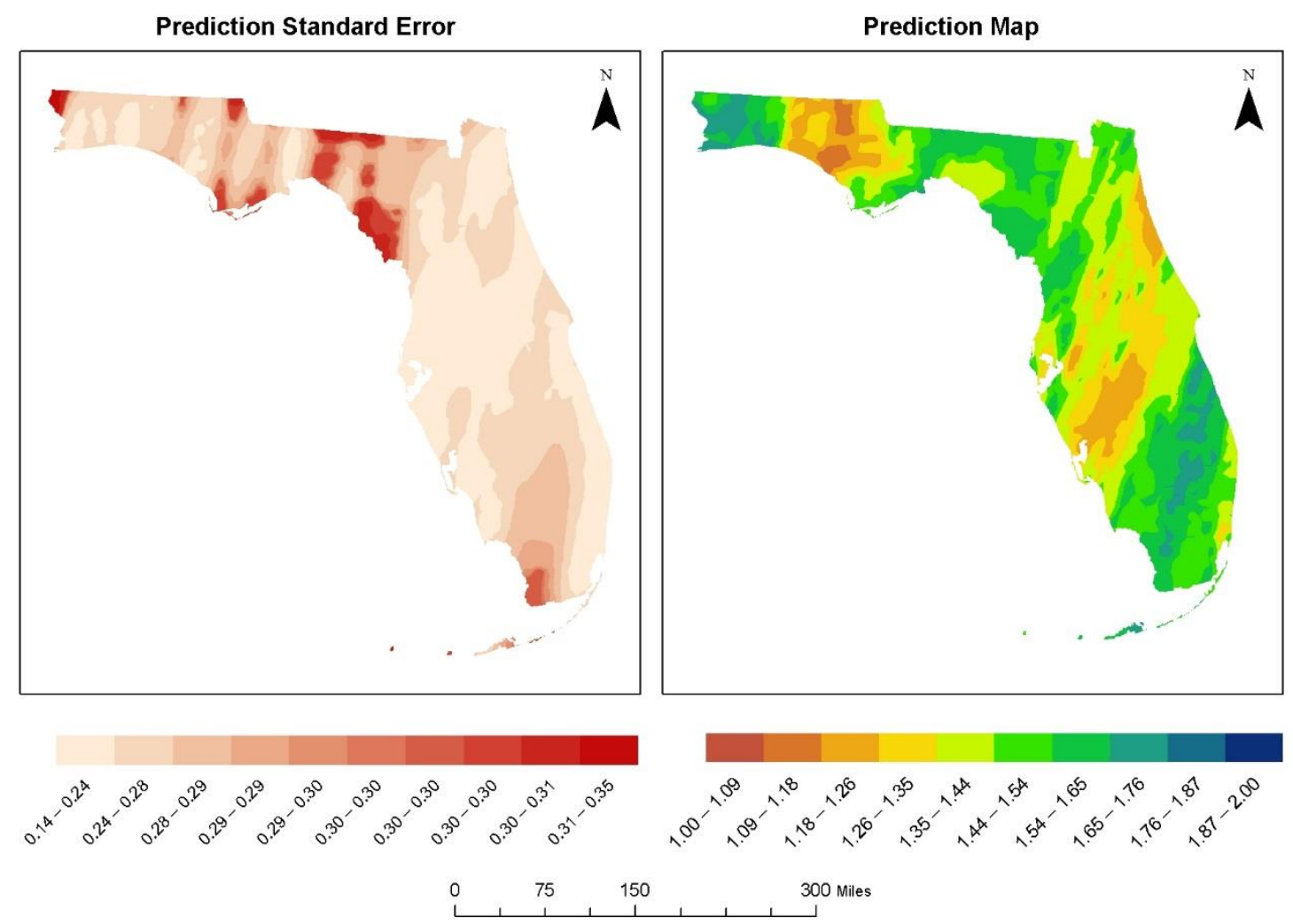

Figure 2-23. Prediction map and prediction standard error for Choice Card Set 1.

The prediction map shows the areas where restoration preference considering the change of above mentioned attributes is high (green and bluish green). The prediction standard error map shows the accuracy of restoration preference map (low value indicates higher accuracy).

Card Set 2 included Reduction of Wetland Species, Dryland Species and Florida Bay Species population, Reduction of Farmland Acreage, Restrictions on outdoor Water Use, and corresponding monetary value for the two levels in the card. The figure below shows the prediction and error map for Card Set 2. 
Interpolation of Stated Restoration Preference for card set 2

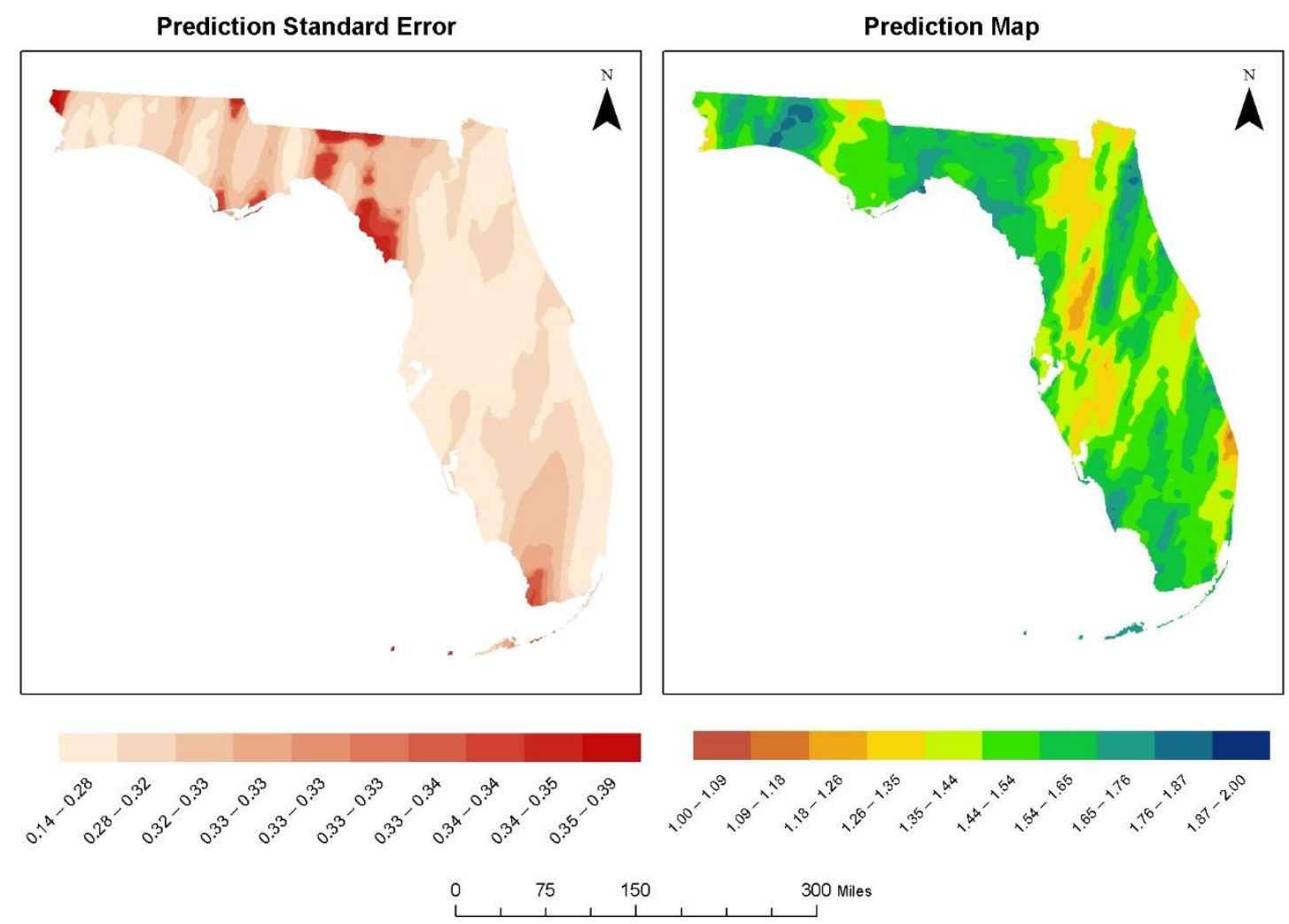

Figure 2-24. Prediction map and prediction standard error for Choice Card Set 2

For Choice Card Sets 3 and 4 there were three different levels instead of two as in Card Sets 1 and 2. The following figure shows the prediction and error map of Card Set 3 which included Fish availability in Lake Okeechobee, Availability of agricultural water, Coastal water quality, and Freshwater quality attributes with three levels of corresponding monetary values added in respondent's annual bill. 


\section{Interpolation of Stated Restoration Preference for card set 3}

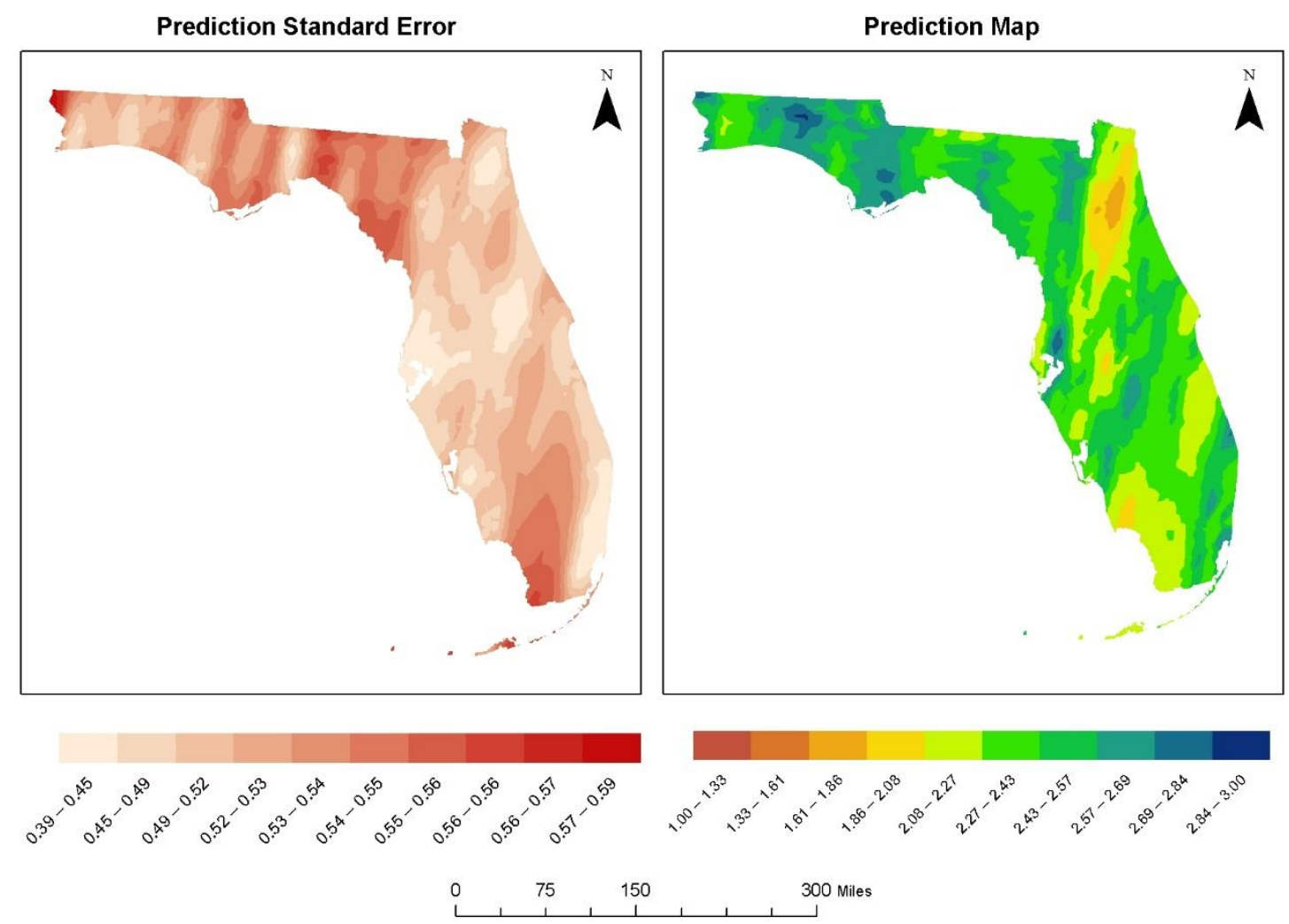

Figure 2-25. Prediction map and prediction standard error for Choice Card Set 3

Finally, the following map was prepared from the data of Choice Card Set 4 that included Inland Mangrove Expansion, Restrictions on Urban Expansion, Water Quality of Estuaries, Municipal Water Supply, Recreation in the Everglades National Park and Urban Flood Risk attributes with corresponding monetary implication on annual bill. 
Interpolation of Stated Restoration Preference for card set 4

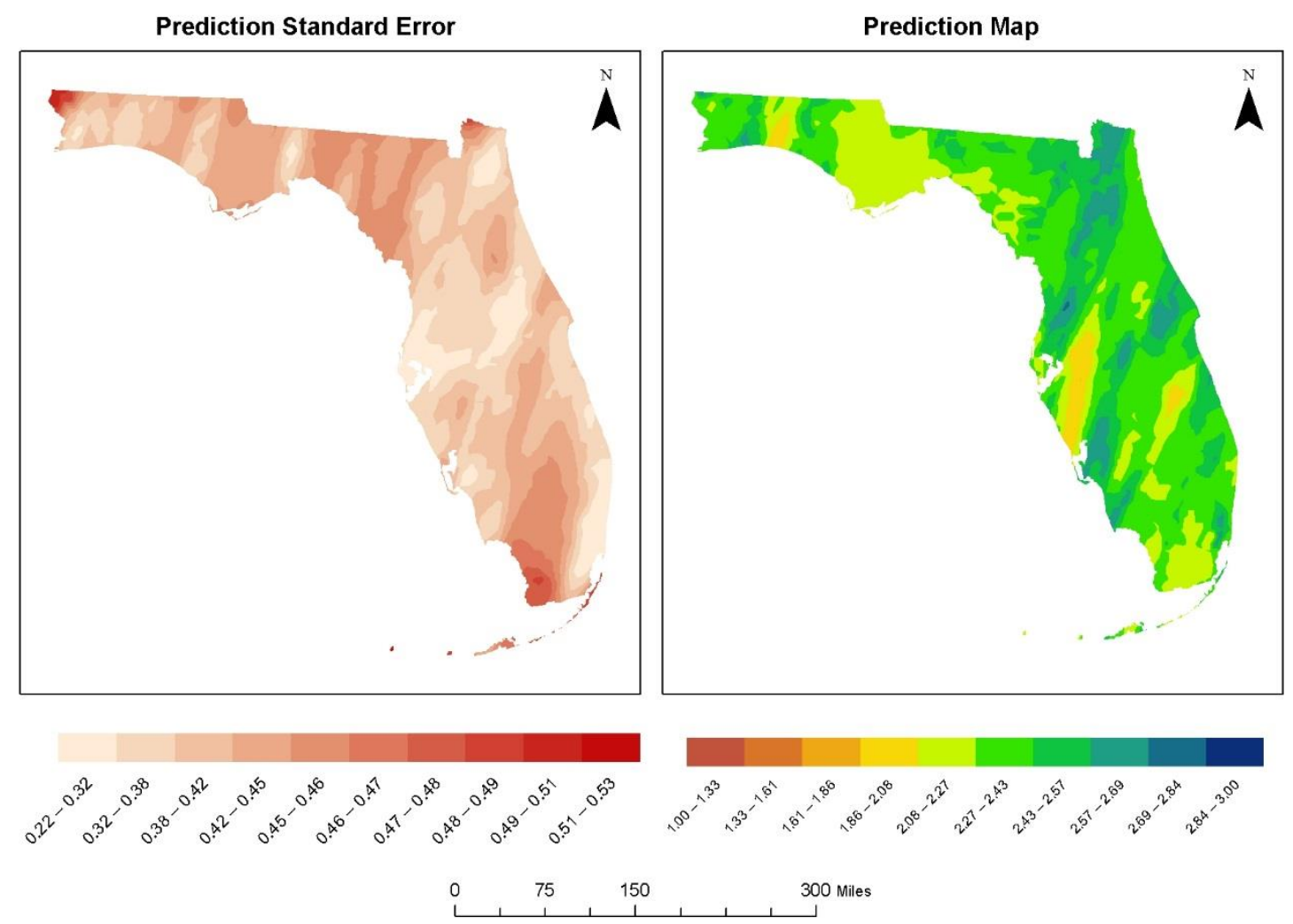

Figure 2-26. Prediction map and prediction standard error for Choice Card Set 4

\subsection{Discussion}

Public preference for the restoration of the Everglades varies depending on the type of ecosystem services that restoration is going to impact. The four sets of choice cards used in the survey were designed in such a way that the attributes collectively represent one single distinct feature of the Everglades ES (e.g., hydrological features, species abundance, ecological features, and urban and recreational services). The first set includes a tradeoff scenario between hydrological attributes and farmland acreage and water use restriction. The prediction map for this set shows a lack of preference for 
restoration mostly in the populated urban areas of Florida. Relatively less preference is also observed in the central region and some parts of the panhandle region of the state. Light green, yellow, and orange colors in Figure 2-23 represent lower preference for restoration considering management of water in the Everglades. Choice Card Set 2 includes various ecosystem-specific species-related attributes and its tradeoff with farmland acreage and water use restriction. In this case the prediction map (Figure 2-24) changed from the previous hydrologic attribute (CC1) map as the distribution of lower preference areas took a different shape and also altered the intensity of color. Northwest Florida showed a strong restoration preference for maintaining species population in the Everglades. An interesting change in this species population map (CC2) compared to the hydrologic attribute (CC1) map is that, both in Miami and Tampa (the two most populated metropolitan areas in Florida), the near-coast urban areas prefer higher restoration for Card Set 2 (species population) attributes.

Choice Card Set 3 included different ecological attributes and their tradeoff with agricultural water supply. The prediction map for CC3 (Figure 2-25) showed a prevalence of strong preference for restoration both in northern and southern parts of the state. Except for a few locations in St. Johns and Duval counties in the northeastern region of the state, most of the areas were predicted to prefer some level of restoration. For the ecological attributes, areas north of Miami produced higher values for restoration preference compared to Tampa. Card Set 4 was presented as a tradeoff between recreational and habitat improvement attributes and urban development attributes. As shown in the prediction map (Figure 2-15), almost the entire state prefers restoration of 
the Everglades when it comes to card set 4 (Inland Mangrove Expansion, Recreation in the Everglades National Park, Water Quality of Estuaries, Municipal Water Supply, Urban Flood Risk, and Restrictions on Urban Expansion) attributes. Only some parts of Polk and Hillsborough counties in West Central Florida showed relatively lower preference for restoration compared to the rest of the state. These four maps present the spatial distribution of public preference for Everglades restoration and the variation of preference for different ES. 


\section{RISK PERCEPTIONS REGARDING CLIMATE CHANGE AND SEA LEVEL RISE ON THE EVERGLADES RESTORATION}

\subsection{Introduction}

The Everglades is a unique ecosystem. Intensive water management in the system by altering the water quality, quantity, temporal and spatial distribution have facilitated agricultural, urban and economic development (Gunderson and Light, 2006). Today, the system is an intricate network of freshwater lakes, rivers, slough, ponds, sawgrass marshes, hardwood hammocks, and forested uplands. The primary source of water in the system is either direct rainfall or indirect inflow from Lake Okeechobee (Nungesser et al., 2014). The landscape of the Everglades is extremely flat and thus sheetflow is predominant way of passing water through the system toward the bay. The system was dredged over the past century by removing water from the regional landscape to provide primarily flood protection (Perry, 2004). The newly developed land provided opportunity for agricultural and urban development and currently the size of Everglades is reduced to $50 \%$ of its original size.

The Everglades system is linked with various economic activities in South Florida. Tourism and outdoor recreation is an important state earning scheme (The Nature Conservancy, 2009), which is substantially dependent on the Everglades. Similarly, the water supply of this region, for both urban and agriculture needs, relies on the Everglades (Obeysekera et al., 2014). The system also provides protection from hurricanes and keeps 
the saline water from intruding into the aquifer. Residents of South Florida benefit both directly and indirectly from the ecosystem services offered by the Everglades.

The system is under imminent threat from climate change. Proximity to mean sea level is going to drastically affect this nearly flat gradient landscape. Sea level rise, changes in rainfall, and increased temperature and evapotranspiration are going to change the way water is managed in this system. Although uncertainty prevails about the shifting magnitude and intensity of different climatic parameters, modeling studies including a $1.5^{\circ} \mathrm{C}$ increase over a 50 year horizon have shown significant alteration of the water budget affecting agriculture, ecosystems, and urban sectors (Obeysekera et al., 2014).

Understanding public perception about the impending changes of such a system that provides numerous ecosystem services to a large number of residents and is highly vulnerable to predicted climatic change is very important. Comprehending differences of opinion and attitudes toward the impending changes and their origins may avoid disagreement and potential barriers to policy implementation, leading to more socially acceptable responses to change (Tam and McDaniels, 2013).

\subsection{Background}

The historic extent of the Everglades was about 11,000 square miles. The rainfalldependent system used to carry water from the Kissimmee River to Lake Okeechobee and then through the low gradient landscape toward Biscayne Bay, Ten Thousand Islands and Florida Bay (Perry, 2004). This slow moving sheet of water created the unique ridge and slough mosaic of the Everglades (Larsen et al., 2011). Early in the 1900s settlers, 
both privately and with state help, started to drain the Everglades with an intention to utilize this unoccupied land for agriculture. While the agricultural triumph was expanding, disastrous flooding was the main problem. To solve this dilemma, the government stepped forward and approved the Central and South Florida Project (C\&SF) to control flooding in 1948. The primary objective of C\&SF was to drain water from the Everglades and convey the majority of annual rainfall runoff to either the east or west coast of Florida. Over 1000 miles of canals, 720 miles of levees, 16 pumping stations, and about 200 control structures were built to facilitate this process. This transformation diminished the Everglades to 50\% of its original spatial extent and the remnant portion is also under continuous threat of water shortage due to urban and agricultural demand, flood control measures, and degraded water quality discharge to the system (Godfrey and Catton, 2011; Perry, 2004). To protect this system from further decay and to restore some resemblance of the historic hydrologic and ecological functions of the Everglades, a multi-billion dollar plan, the Comprehensive Everglades Restoration Plan (CERP) was finalized in 2000 (Perry, 2004). This three decades long initiative is the largest environmental restoration attempt in the United States and comprises of more than 60 components.

The Everglades is highly susceptible to impending climate change. Predicted change in sea level rise, evapotranspiration, temperature, and more importantly rainfall runoff is going to alter the system extensively (Aumen et al., 2015). Orem et al. (2014), projected the response of the soil biogeochemistry, particularly carbon, nitrogen, phosphorus, sulfur, and mercury, due to climate change scenarios for 2060 from the South Florida 
Water Management Model. They showed precipitation is the stronger driver for biogeochemical process in the system and reduced rainfall would result in dry-down, organic soil oxidation, and shifts in soil redox in large portions of the Everglades, and may make portions of the Everglades more vulnerable to sea level rise due to lowering organic soil surface elevation. Saha et al. (2011) conducted a study on Everglades National Park that showed that even prior to the actual permanent inundation due to sea level rise, the drought and salinity stress will diminish hardwood hammocks and coastal buttonwood forests. Study of climate change impact on Lake Okeechobee, considered as the liquid heart of South Florida, showed that decreased rainfall will significantly lower the water level of the lake and affect the littoral zone and submerged vegetation, and intense rainfall events will increase the lake level over historic ranges (Havens and Steinman, 2013). Similarly, climate change imposes severe threats to the peat soil of the system, which was built over thousands of years; it will affect the unique ridge and slough mosaic significantly. An increase in temperature may increase incidents of wildfire (Nungesser et al., 2014). Finally, all these alterations will affect the habitat, population and distribution of several endemic plants and species (Catano et al., 2014; Valk, Arnold G et al., 2015).

In the current scope of CERP, consideration of climate change effects is limited to evaluations of sea-level rise scenarios as a check on performance of the selected plan (Estenoz and Bush, 2015). Although different meticulous posits have been made by scientists about the potential ramifications of climate change on various components of Everglades, uncertainty exists in forecasting the likely consequences of management 
action and inaction (National Research Council, 2014). In this regard, effective decision making under risk and uncertainty dictates careful consideration of scientific knowledge as well as social values, preferences, or utilities. Investigating social parameters is important as they are subjective and usually differ across stakeholders (Borsuk et al., 2001; Estenoz and Bush, 2015).

Navigating the expectation and concerns of stakeholders and understanding their opinions and attitudes is always important for socially accepted decision making (Tam and McDaniels, 2013). Although, the physical science aspects of Everglades have been studied extensively, the human dimension of this system has received little attention (Schwartz, 2013). A study on the Florida Keys by Zhang et al. (2011), showed that a 0.6 meter sea level rise will affect about $17 \%$ of the population and $12 \%$ of the properties and inundate $70 \%$ of the land area. Although the study focused on the Florida Keys, it provided an insight of the impact of sea level rise in low lying areas of Florida and how this is going to affect the population and economy. A study conducted by Mozumder et al. (2011) on the risk perception of experts and decision makers showed that a large majority of respondents recognize the impending ramifications of climate change in the Florida Keys, however, very few mentioned having a formal adaptation plan within their respective agencies. Flugman et al. (2012) in a separate study, conducted on the Florida Keys, proposed the establishment of 'Community Adaptation Fund' as a potential financial mechanism to enhance adaptive capacity in the study area and beyond. While these studies provide an overarching insight into decision makers' perspectives regarding climate change and its adaptation, perceptions of the largest group, the general public, 
were not reflected adequately. As highlighted by Chilvers et al. (2014) for climate change impact studies on the marine environment, understanding social dynamics is an often neglected yet highly important aspect of the problem. Therefore, this study tried to explore public perception regarding climate change.

\subsection{Survey Design and Data Collection}

We conducted an online survey and the sample size included 949 complete responses from the residents for Florida. Qualtrics survey software was used for this purpose. An invitation email was sent to the respondents with a web link to the questionnaire page to participate in the study. Four illustrative videos each about five minutes were included in the survey to explain different major natural process of Everglades and the ramifications of altering this process due to climate change. Table 3.1 shows sociodemographic characteristics of the sample and compared with state statistics.

Table 3-1. Comparison of sociodemographic characteristics of survey respondents and census 2010 for the state of Florida

\begin{tabular}{|c|c|c|c|}
\hline \multicolumn{2}{|l|}{ Survey sample } & \multirow{2}{*}{$\begin{array}{l}\begin{array}{l}\text { Sample } \\
\text { characteristics }\end{array} \\
\text { Percentage }\end{array}$} & \multirow{2}{*}{$\begin{array}{l}\text { State of Florid } \\
2010 \text { census } \\
\text { characteristics } \\
\text { Percentage }\end{array}$} \\
\hline Characteristics & & & \\
\hline Mean age & & 57.9 & 40.7 \\
\hline \multirow[t]{2}{*}{ Gender } & Male & 64.74 & 48.9 \\
\hline & Female & 35.26 & 51.1 \\
\hline Race & White/Caucasian & 79.3 & 65.7 \\
\hline
\end{tabular}




\begin{tabular}{lllll}
\hline Survey sample & & $\begin{array}{l}\text { Sample } \\
\text { characteristics }\end{array}$ & & $\begin{array}{l}\text { State of Florid } \\
2010 \text { census } \\
\text { characteristics }\end{array}$ \\
\cline { 2 - 4 } Characteristics & & Percentage & Percentage \\
\hline & African American & 2.2 & 14.6 \\
& Hispanic & 9.1 & 16.4 \\
& Asian & 0.7 & 1.7 \\
& $\begin{array}{l}\text { Native American } \\
\text { Pacific Islander }\end{array}$ & 0.1 & 0.3 \\
& $\begin{array}{l}\text { Other } \\
\text { Choose not to }\end{array}$ & 7.1 & 0.1 \\
\hline $\begin{array}{l}\text { indicate } \\
\text { Attainment }\end{array}$ & $\begin{array}{l}\text { High school } \\
\text { graduate }\end{array}$ & 11.7 & 28.2 \\
Bachelor's degree & 33.0 & 17.9 \\
\hline
\end{tabular}

\subsection{Empirical Analysis}

Given the ordered nature of the variables of interest we used ordered logistic regression to understand the relationship. The Ordered logistic regression or ordinal regression is a technique of modeling ordinal or categorical dependent variables with a set of independent variables. Ordinal outcome of a variable may include ordered data such as 'very good', 'good', 'moderate' and 'poor' or 'strongly agree', 'agree', 'disagree' and 'strongly disagree'. Regardless of the terminology or the way the data are coded, there should be a lucid ordering sequence of the variable categories (Hosmer et al., 2013). The 
model can be considered as an extension of the binary logistic regression allowing more than two ordered categories. Whereas a binary logistic model provides a relationship between dependent and independent variables given that the dependent variable has only two categories, ordered regression allows managing more than two ordered categories. The expected value of Y given $\mathrm{x}$ for a binary logit model can be expressed by equation 31.

$E(Y \mid x)=\pi(x)=\frac{e^{\beta_{0}+\beta_{1} x}}{1+e^{\beta_{0}+\beta_{1} x}}$

For binary response, the convention is $Y=0$ or $Y=1$. So taking the natural logarithm of the odds ratio of the expected values, the logit function can be written as equation 3-2.

$g(x)=\ln \left[\frac{\pi(x)}{1-\pi(x)}\right]=\beta_{0}+\beta_{1} x$

Now, in case of ordered logit, instead of two, there are more than two categories in the dependent variable. There are three major approaches commonly used to model this type of variable. These are adjacent-category logistic model, where one response is compared to the next large response, continuation-ratio logistic model, where a response is compared with all the responses lower than that and the third one is proportional odds model that compared the probability of an equal or smaller response to a larger response. In this study the latter mentioned model was used. The logit function of the model can be written as (equation 3-3),

$c_{k}(x)=\ln \left[\frac{p(Y \leq k \mid x)}{p(Y>k \mid x)}\right]=\alpha_{k}-\boldsymbol{x}^{\prime} \boldsymbol{\beta}$ 
Where $k=0,1, \ldots,(\mathrm{k}-1)$ denotes the number of categories of the dependent variable, $Y$ is the target outcome or the cut-point, $\alpha_{k}$ is the intercept and $\beta$ is the slope coefficient. When $k=1$, this model simplifies to binary logistic model. The underlying assumption of the proportional odds model is the odds ratios are invariant to where the outcome categories are dichotomized: i.e., odds ratio of category 0 and 1 will the same as odds ratio of category 3 and 4 of a five category variable (Kleinbaum and Klein, 2010).

\subsection{Analysis of the Survey Data}

The survey was conducted with people who live in the state of Florida and 949 samples were considered for the study after removing the unusable data. The samples are distributed all over the state, although the density varies based on the distribution of population at different parts. Figure 3.1 shows geographic location of the survey sample. 


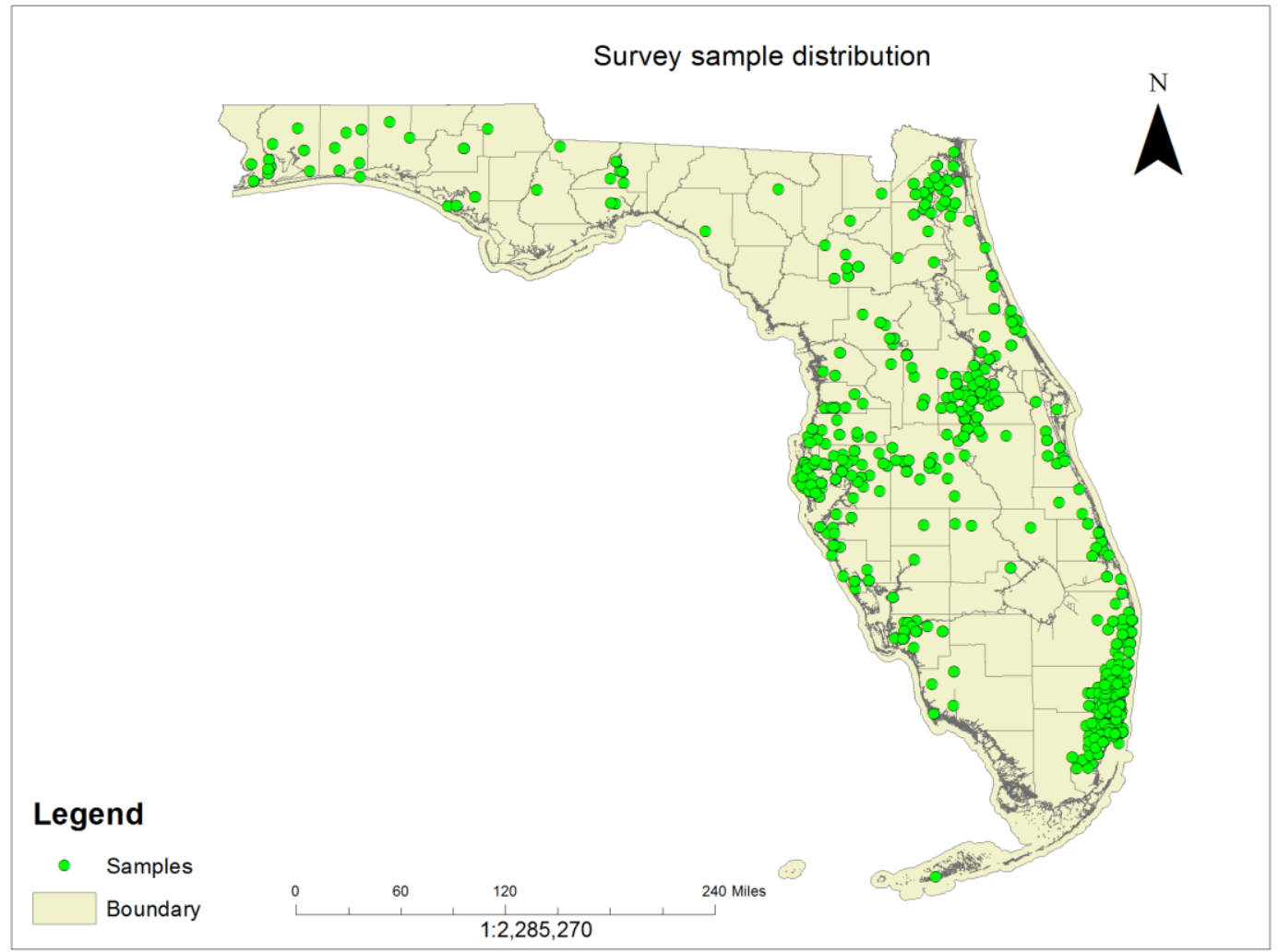

Figure 3-1. Spatial distribution of respondent's location in Florida.

Except for some northern and central parts, much of the state is relatively flat and elevation is not significantly greater than mean sea level. Therefore, a majority of the samples were located in low lying areas. Figure 3.2 presents the relationship between distance from shore and elevation of the households' location. The smoothed conditional mean line between these two variables shows that distances are not always positively related. 


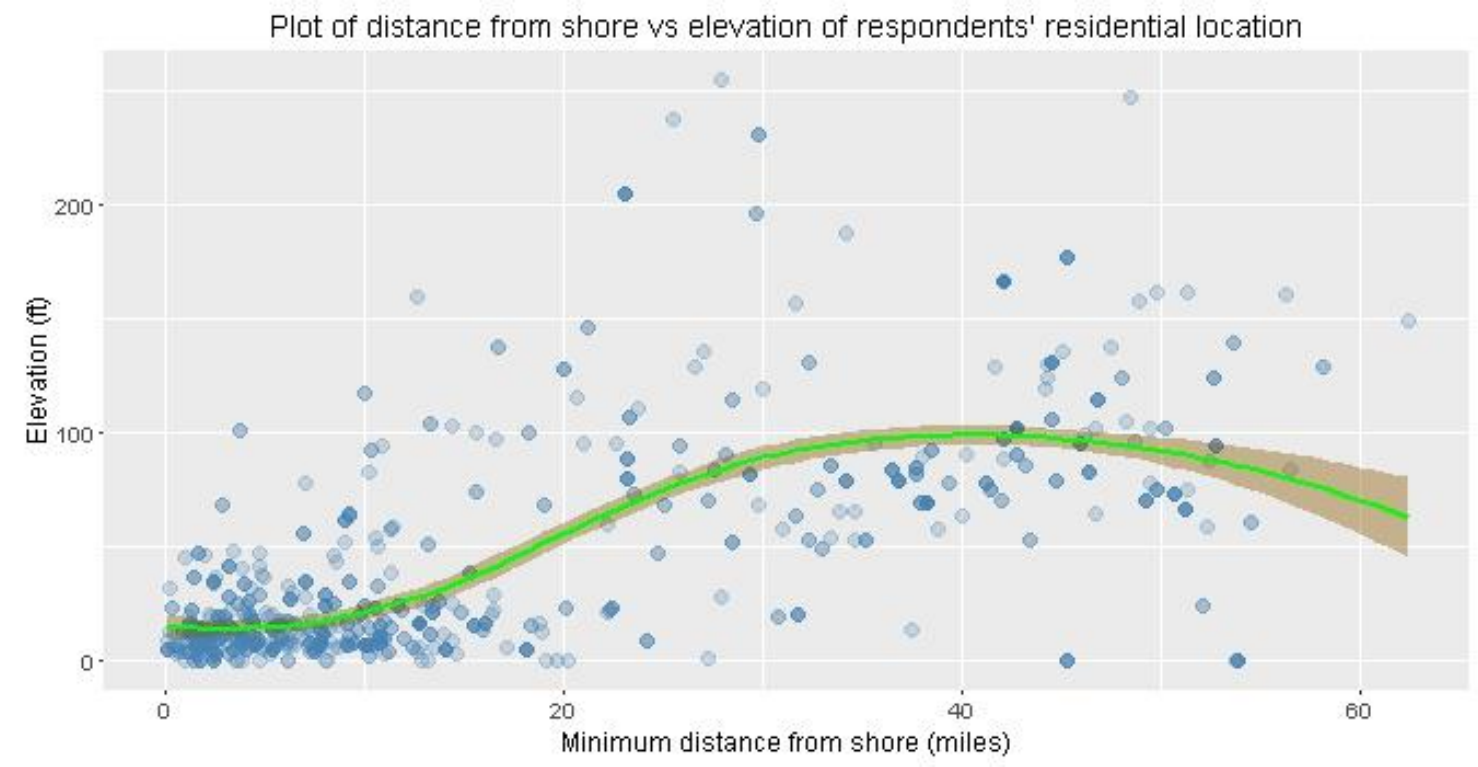

Figure 3-2. Distance from shore vs elevation of respondents' residential location

As stated above, the study attempted to understand people's perception of the risk of climate change and sea level rise impacts together with two management issues: restoration of the Everglades and urban expansion in the low lying areas. Therefore, different socio-demographic factors as well as their stated importance of various ecosystem services were related with their responses to three questions to see the correlation among them. A description of the three questions are given in Table 3.2. 
Table 3-2. Climate change related questions and their scaling system

\begin{tabular}{|l|l|l|}
\hline Questions & Likert scale & $\begin{array}{l}\text { Total } \\
\text { responses }\end{array}$ \\
\hline $\begin{array}{l}\text { Risk Perception (RP): Climate change and } \\
\text { its impacts such as increased sea level rise } \\
\text { pose a substantial risk to the functionality } \\
\text { and sustainability of the ecosystem services } \\
\text { provided by the Everglades }\end{array}$ & $\begin{array}{l}\text { Strongly disagree =1 } \\
\text { Disagree= } \\
\text { Neutral= } \\
\text { Agree=4 } \\
\text { Strongly agree= 5 }\end{array}$ & 949 \\
\hline $\begin{array}{l}\text { Everglades Restoration (ER): Due to sea } \\
\text { level rise and its impact such as intrusion of } \\
\text { saltwater we need to be more aggressive } \\
\text { about Everglades Restoration. }\end{array}$ & $\begin{array}{l}\text { Strongly disagree = } \\
\text { Disagree= } \\
\text { Neutral= 3 } \\
\text { Agree=4 } \\
\text { Strongly agree=5 }\end{array}$ & 949 \\
\hline $\begin{array}{l}\text { Restrict Development (RD): Due to climate } \\
\text { change and sea level rise we should restrict } \\
\text { further development in low lying coastal } \\
\text { areas in Florida. }\end{array}$ & $\begin{array}{l}\text { Strongly disagree =1 } \\
\text { Disagree=2 } \\
\text { Neutral=3 } \\
\text { Agree=4 } \\
\text { Strongly agree=5 }\end{array}$ & 949 \\
\hline
\end{tabular}

Table 3.3 includes a brief description of the explanatory variables. The mean and standard deviation of those variables were also included in the table. In cases where a coded value was used instead of an actual value to categorize the entries of a variable, the coding scale was included in the description column (e.g., Education was categorized into seven levels). 
Table 3-3. Description of explanatory variable with descriptive statistics

\begin{tabular}{|c|c|c|c|}
\hline Variable & Description & Mean & SD \\
\hline Elevation & $\begin{array}{l}\text { Elevation of the respondents' household location } \\
\text { from sea level (in feet, calculated using latitude } \\
\text { and longitude of the houses and statewide 5- } \\
\text { meter digital elevation model in ArcGIS.) }\end{array}$ & 44.16 & 48.10 \\
\hline Env vs Eco & $\begin{array}{l}\text { Respondents' rating whether economic growth or } \\
\text { protecting environment should be given more } \\
\text { importance during public policy decisions (on a } \\
\text { scale of } 1 \text { to } 7,1 \text { being high priority in protecting } \\
\text { environment and } 7 \text { being prioritizing economic } \\
\text { growth). }\end{array}$ & 3.27 & 1.62 \\
\hline Beach visit & $\begin{array}{l}\text { Respondents' rating frequency of visiting beach } \\
\text { as part of recreational activity (on a scale of } 1 \text { to } \\
7,1=\text { more than once a week, } 2=\text { more than } \\
\text { once a month, } 3=\text { more than once every three } \\
\text { months, } 4=\text { more than once every six months, } \\
\text { and } 7=\text { never). }\end{array}$ & 3.72 & 1.78 \\
\hline $\begin{array}{l}\text { Shore } \\
\text { distance }\end{array}$ & $\begin{array}{l}\text { Distance of the respondents' households location } \\
\text { form the shoreline (in miles, calculated using } \\
\text { latitude and longitude of the houses and detailed } \\
\text { shoreline shapefile in ArcGIS.) }\end{array}$ & 17.56 & 16.82 \\
\hline $\begin{array}{l}\text { (Shore } \\
\text { distance })^{2}\end{array}$ & Square of the shore distance & 591.00 & $\begin{array}{l}851.3 \\
7\end{array}$ \\
\hline $\begin{array}{l}\text { Recreation } \\
\text { access }\end{array}$ & $\begin{array}{l}\text { Respondents rated on a scale of } 1 \text { to } 5 \text {, how they } \\
\text { prioritize the access to different recreational } \\
\text { opportunities while selecting a restoration plan } \\
\text { for Everglades provided that restoration would } \\
\text { increase access (in a scale of } 1 \text { to } 5,1 \text { being not }\end{array}$ & 3.60 & 1.15 \\
\hline
\end{tabular}




\begin{tabular}{|c|c|c|c|}
\hline Variable & Description & Mean & SD \\
\hline & $\begin{array}{l}\text { at all important and } 5 \text { being extremely } \\
\text { important). }\end{array}$ & & \\
\hline $\begin{array}{l}\text { Urban } \\
\text { flood }\end{array}$ & $\begin{array}{l}\text { Respondents' rating in prioritizing their concern } \\
\text { of urban flooding while selecting a restoration } \\
\text { plan for Everglades provided that restoration } \\
\text { would increase flooding ( } 1 \text { being not at all } \\
\text { important and } 5 \text { being extremely important). }\end{array}$ & 3.96 & 0.98 \\
\hline $\begin{array}{l}\text { Urban } \\
\text { expansion }\end{array}$ & $\begin{array}{l}\text { Respondents rated on a scale of } 1 \text { to } 5 \text {, how they } \\
\text { prioritize the restriction in urban expansion while } \\
\text { selecting a restoration plan for Everglades } \\
\text { provided that restoration would restrict } \\
\text { expansion ( } 1 \text { being not at all important and } 5 \\
\text { being extremely important). }\end{array}$ & 3.91 & 1.03 \\
\hline $\begin{array}{l}\text { Water } \\
\text { supplies }\end{array}$ & $\begin{array}{l}\text { Respondents rated on a scale of } 1 \text { to } 5 \text {, how they } \\
\text { prioritize the improvement of municipal water } \\
\text { supply while selecting a restoration plan for } \\
\text { Everglades provided that restoration would } \\
\text { improve the water supply ( } 1 \text { being not at all } \\
\text { important and } 5 \text { being extremely important). }\end{array}$ & 4.14 & 0.83 \\
\hline Education & $\begin{array}{l}\text { Respondent's highest level of education } \\
\text { completed on a scale of } 1 \text { to } 7 \text { (1. Less than high } \\
\text { school diploma, } 2 \text {. High school diploma, 3. 2- } \\
\text { years college degree, 4. 4-years college degree, } \\
\text { 5. Master's degree, 6. Professional degree, } 7 \text {. } \\
\text { Doctoral degree). }\end{array}$ & 3.19 & 1.20 \\
\hline Income & $\begin{array}{l}\text { Respondent's median household income in a } \\
\text { scale of } 1 \text { to } 20 \text { ( } 1 \text { as less than } \$ 20,000 \text { and } \\
\text { afterward an increment of } \$ 10,000 \text { for one level } \\
\text { increase till } \$ 200,000 \text { and the last level was } \\
\text { above } \$ 200,000) \text {. }\end{array}$ & 4.70 & 3.39 \\
\hline
\end{tabular}




\begin{tabular}{|c|c|c|c|}
\hline Variable & Description & Mean & SD \\
\hline Age & $\begin{array}{l}\text { Respondent's age in years, collected as numeric } \\
\text { entry. }\end{array}$ & 43.96 & 16.42 \\
\hline Residency & $\begin{array}{l}\text { Respondent's duration of residency in Florida (in } \\
\text { years). }\end{array}$ & 23.16 & 15.08 \\
\hline Gender & Gender of the respondent $(1=$ female, $0=$ male $)$ & 0.37 & NA \\
\hline Env degree & $\begin{array}{l}\text { A binary variable assessing if respondent } \\
\text { possesses a degree in environment or the } \\
\text { physical sciences }(1=\text { Yes, } 0=\text { No). }\end{array}$ & 0.07 & NA \\
\hline Swimming & $\begin{array}{l}\text { Respondents rated their frequency of going for } \\
\text { outdoor swimming as part of recreational activity } \\
\text { in a scale of } 1 \text { to } 7 \text { ( } 1 \text { being more than one a } \\
\text { week and } 7 \text { being never). }\end{array}$ & 4.88 & 2.06 \\
\hline Fishing & $\begin{array}{l}\text { Respondents rated their frequency of going for } \\
\text { outdoor fishing as part of recreational activity in } \\
\text { a scale of } 1 \text { to } 7 \text { ( } 1 \text { being more than one a week } \\
\text { and } 7 \text { being never). }\end{array}$ & 5.00 & 2.02 \\
\hline
\end{tabular}

The correlations between these variables are presented in Appendix I. For almost every pair of variables the correlation coefficient was less than 0.5 . To further investigate the correlation between these three questions with the explanatory variables, they were plotted against each of them. Figure 3.3, shows the relationship between respondents' response for the Risk Perception (RP) question and distance from shore and elevation of their household location. Figure 3.4 shows relationship between the response for the 
Everglades Restoration (ER) question and distance from shore and elevation of their household location. Finally, the same relationship for Restrict Development (RD) question was shown in Figure 3.5. The coding of the three questions were same where strong disagreement coded as $\mathrm{SD}$, disagreement as $\mathrm{D}$, neither agree nor disagree as $\mathrm{N}$, agreement as A and strong agreement as SA.
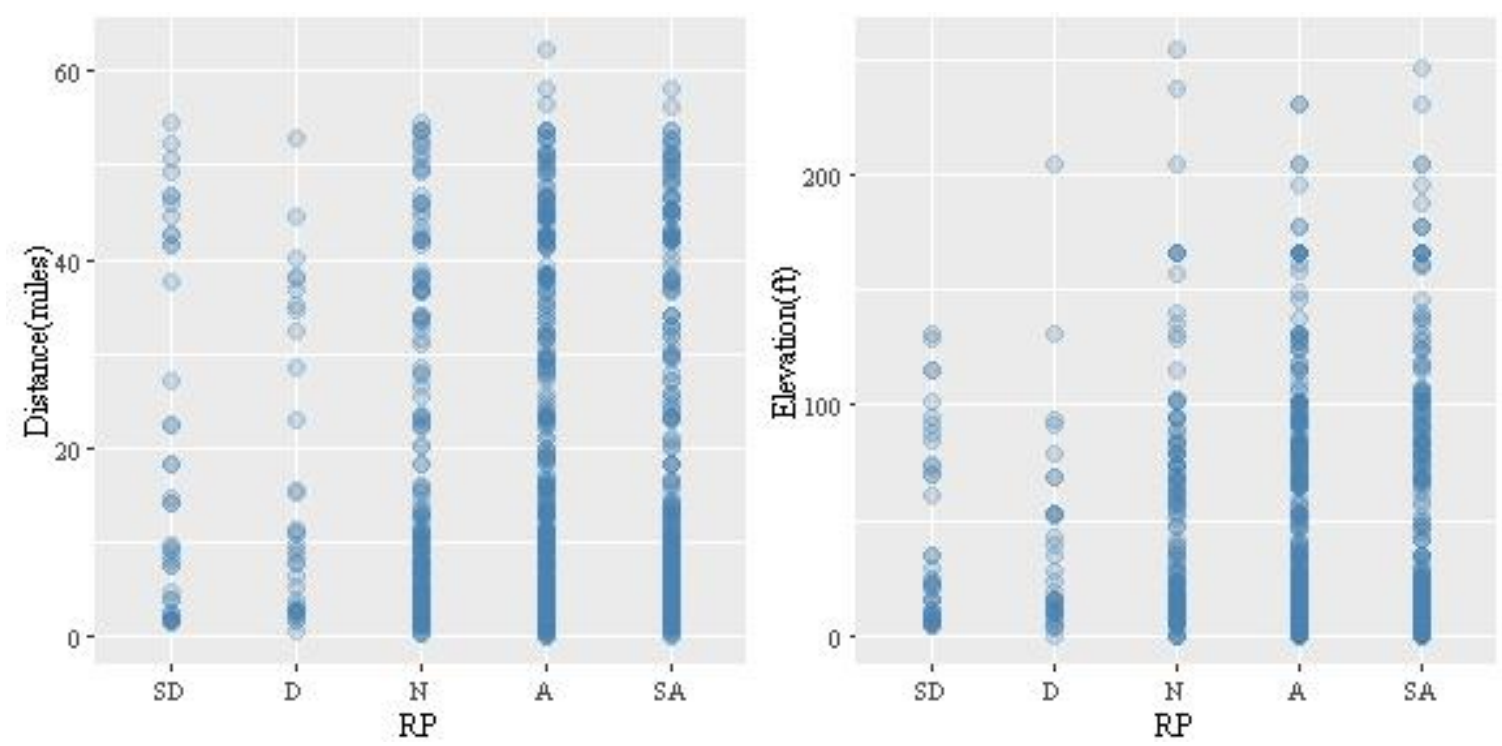

Figure 3-3. Response of RP question vs distance from shore and elevation 

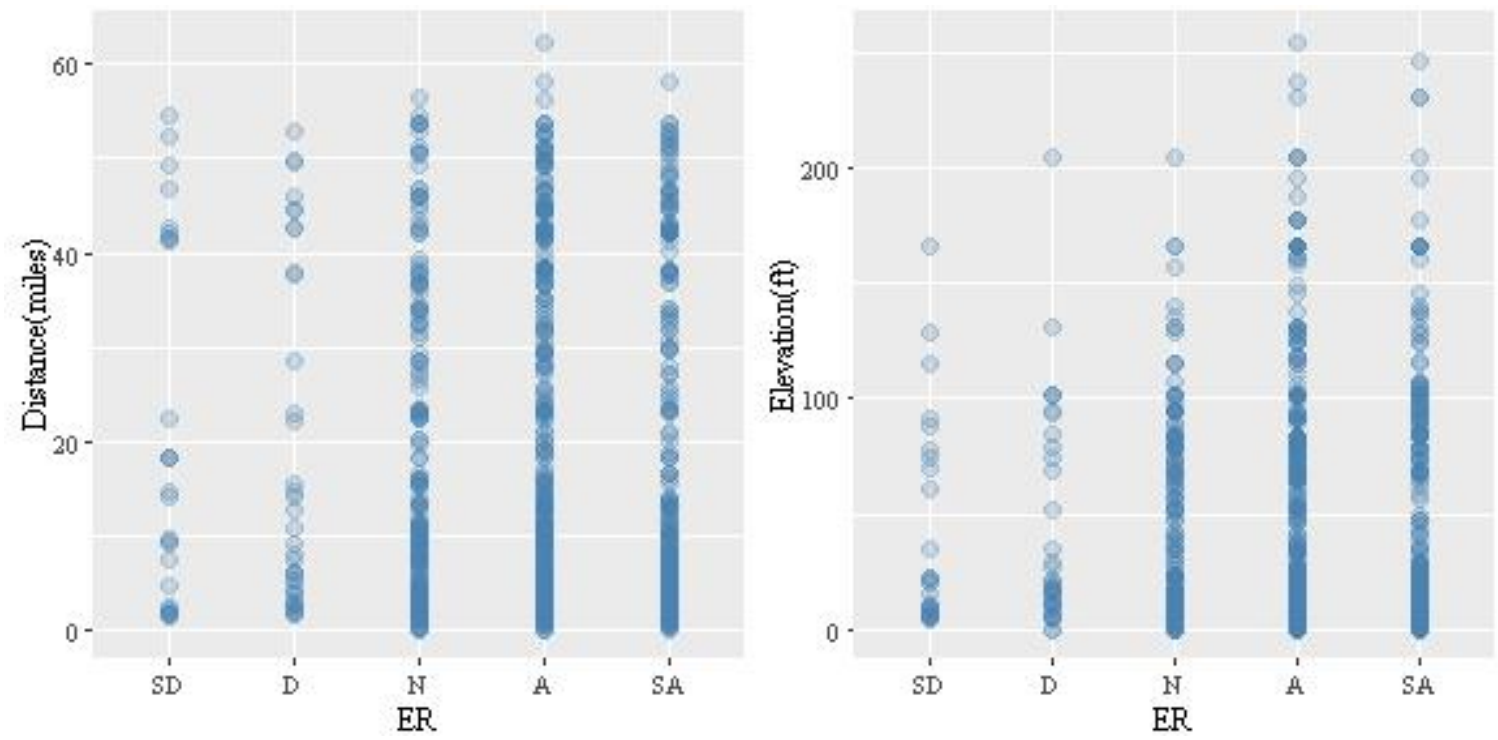

Figure 3-4. Response of ER question vs distance from shore and elevation
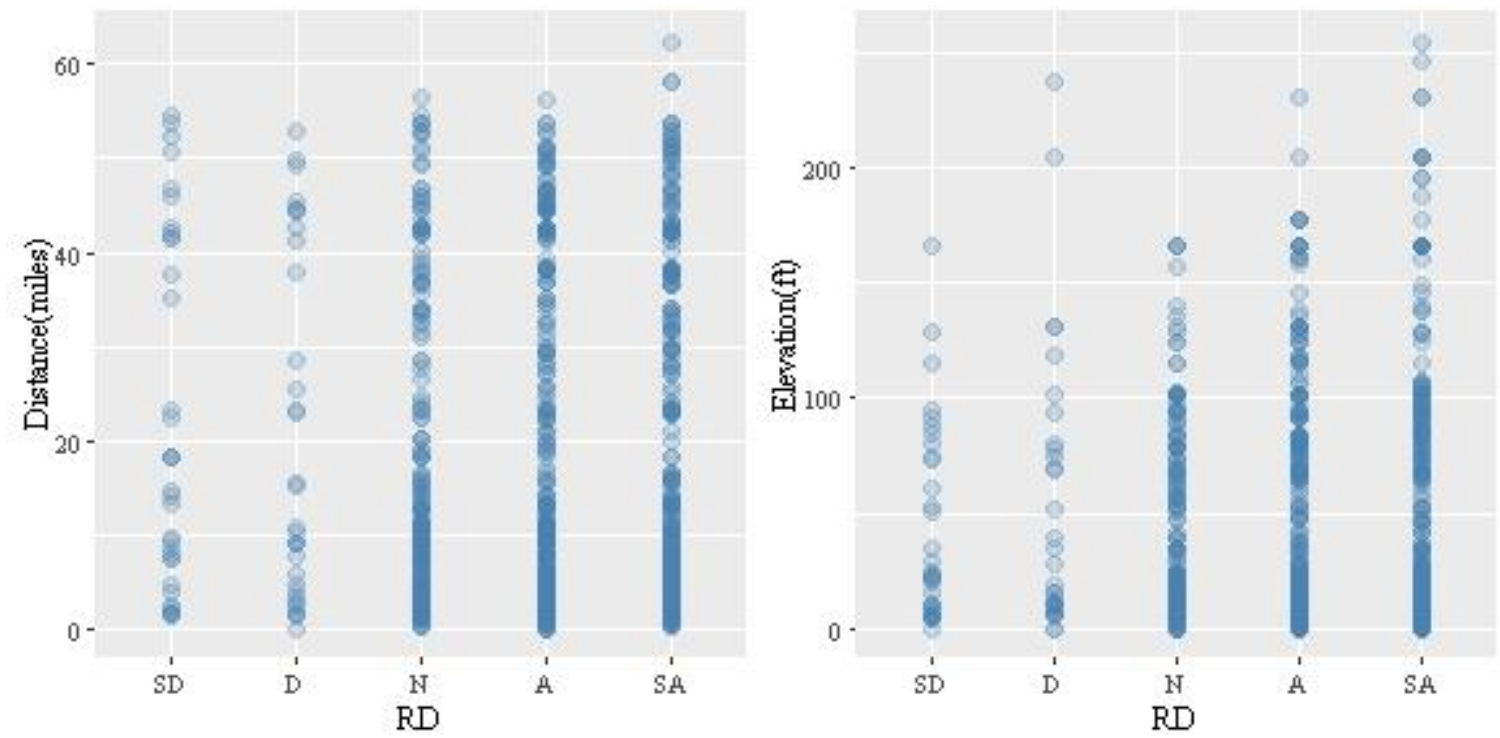

Figure 3-5. Response of RD question vs distance from shore and elevation

Note: SD, D, N, A, SA indicates strongly disagree, disagree, neutral, agree and strongly agree respectively.

Figure 3-6 below shows the relationship between the response of the three questions and public's stated importance for urban expansion. Figure 3-7 shows the response of the 
three questions and importance of maintaining water supply in urban areas and Figure 3-8 shows the response against importance of reducing urban floor risk. In all these three figures, the stated importance was coded using a scale of 1 to 5 with 1 being not important at all and 5 being very important.

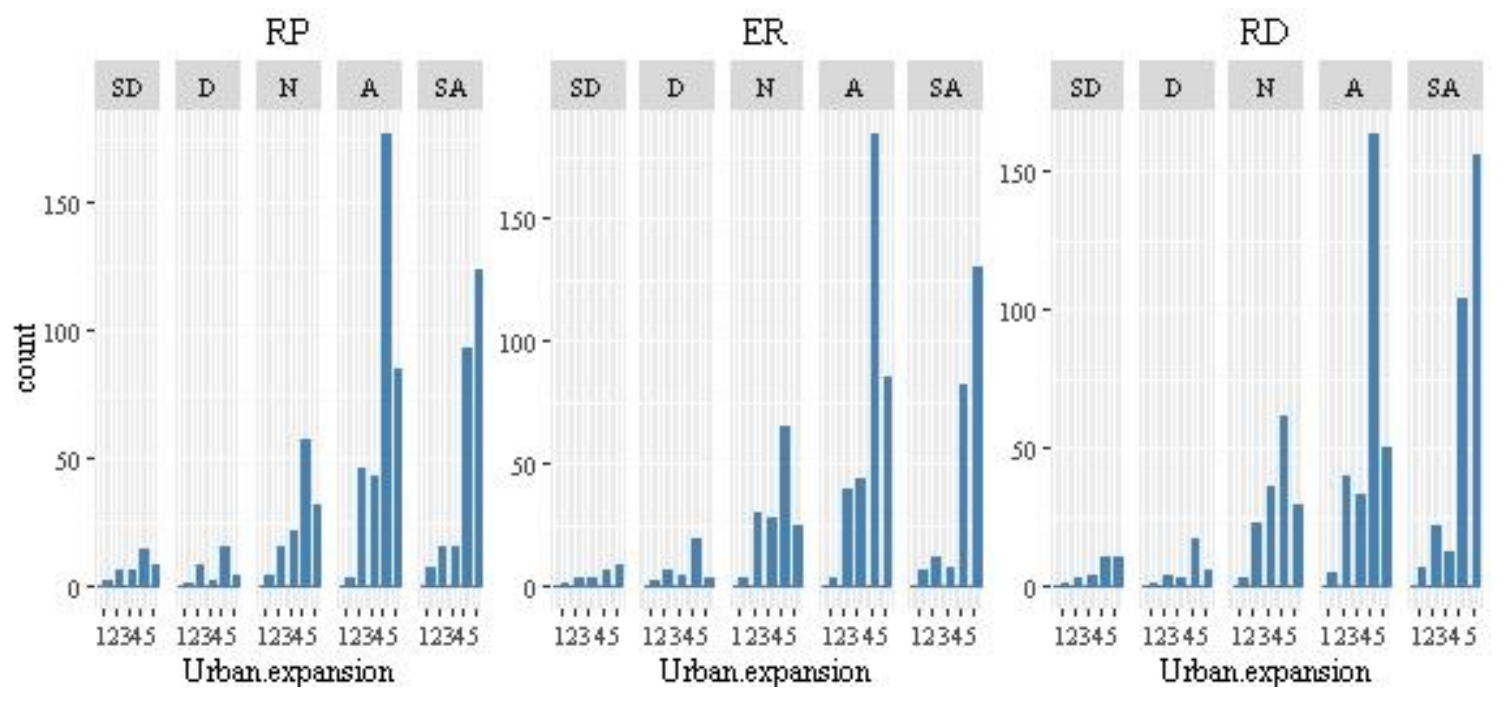

Figure 3-6. Response of the three questions vs urban development

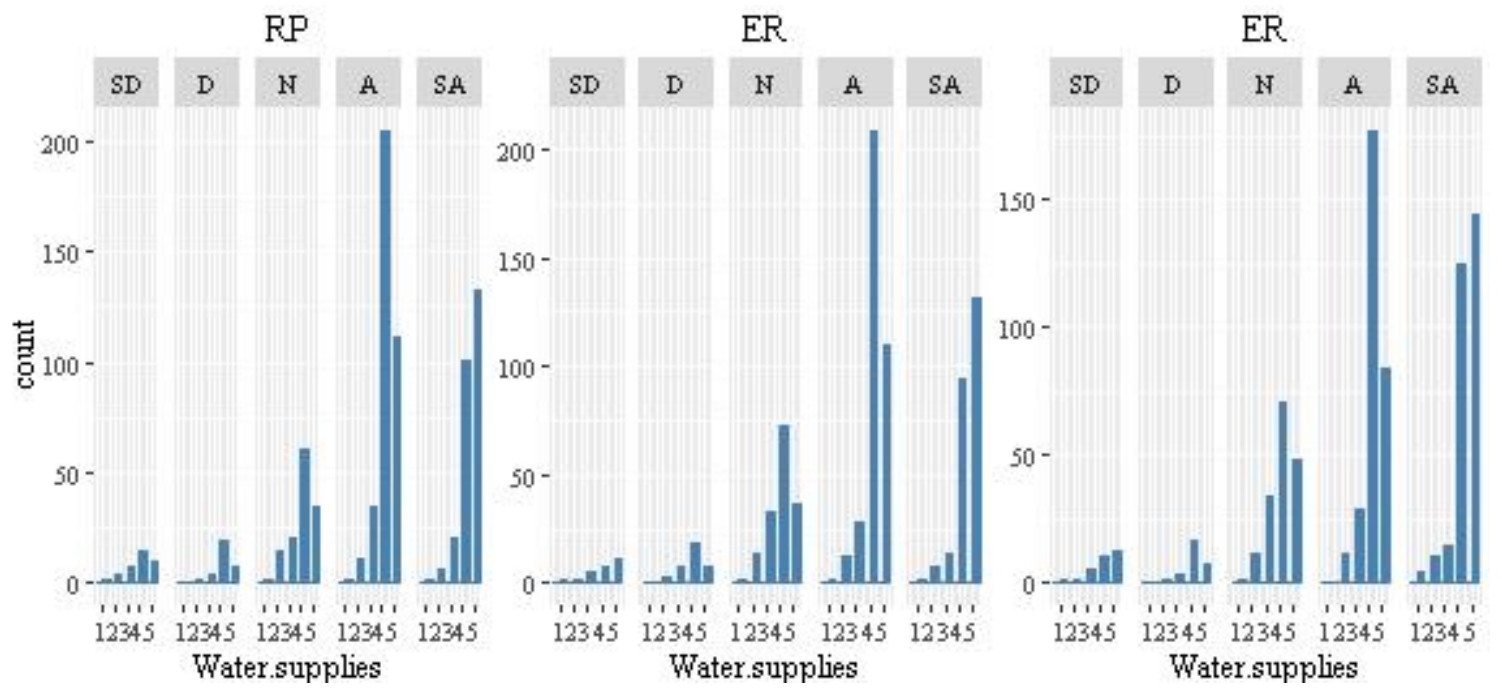

Figure 3-7. Response of the three questions vs urban water supply 


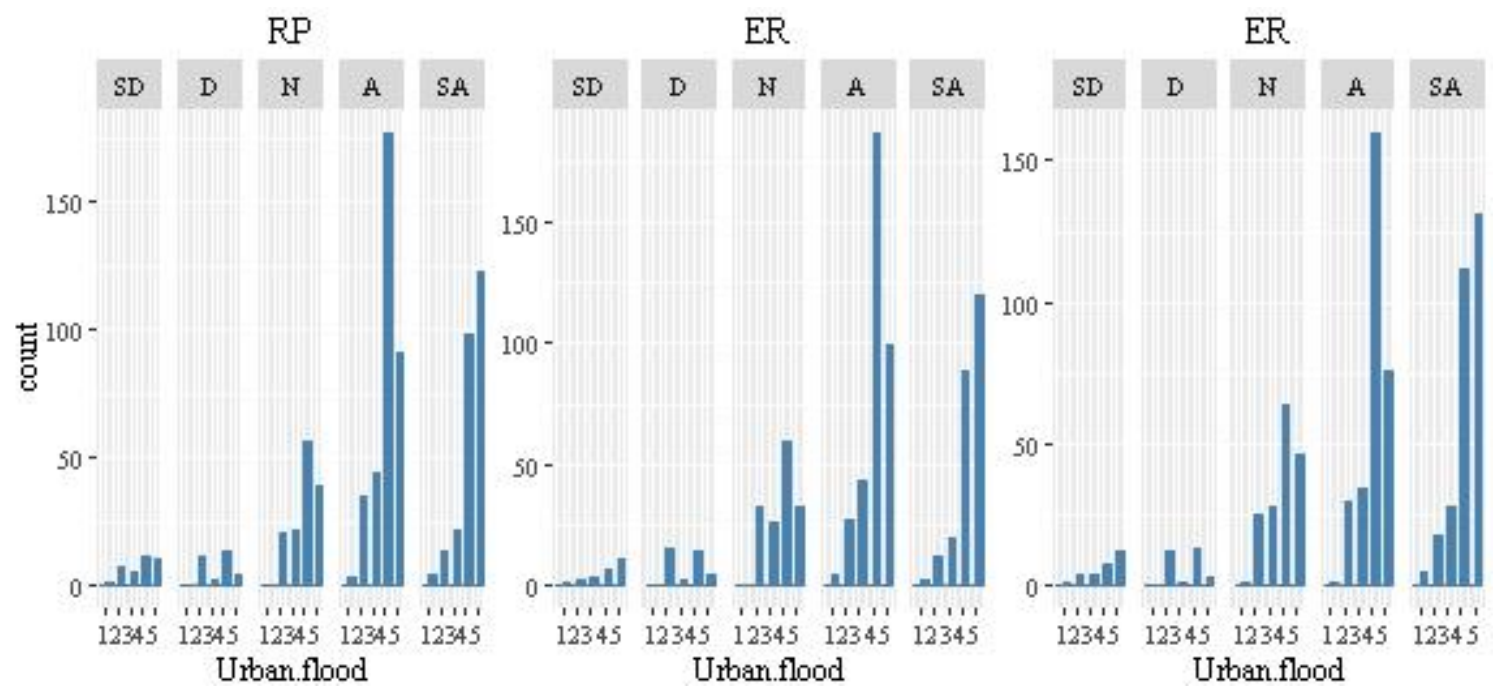

Figure 3-8. Response of the three questions vs reduction of urban flood

Respondents were also asked to rate on a scale of 1 to 7 how important environmental protection is over economic growth during public policy decision ( 1 being full environmental protection and 7 being complete economic growth). Response to this question was shown against the response of the three climate change related question in Figure 3.9.

Respondents were also asked how frequently they participate in different outdoor recreational activities. They were asked to select a value between 1 to 7 where 1 means more than once a week and 7 means never. Their response for beach visit, swimming, and fishing in relation to RP, ER and DR questions are shown in Figure 3-10, 3-11 and 3-12 respectively. 


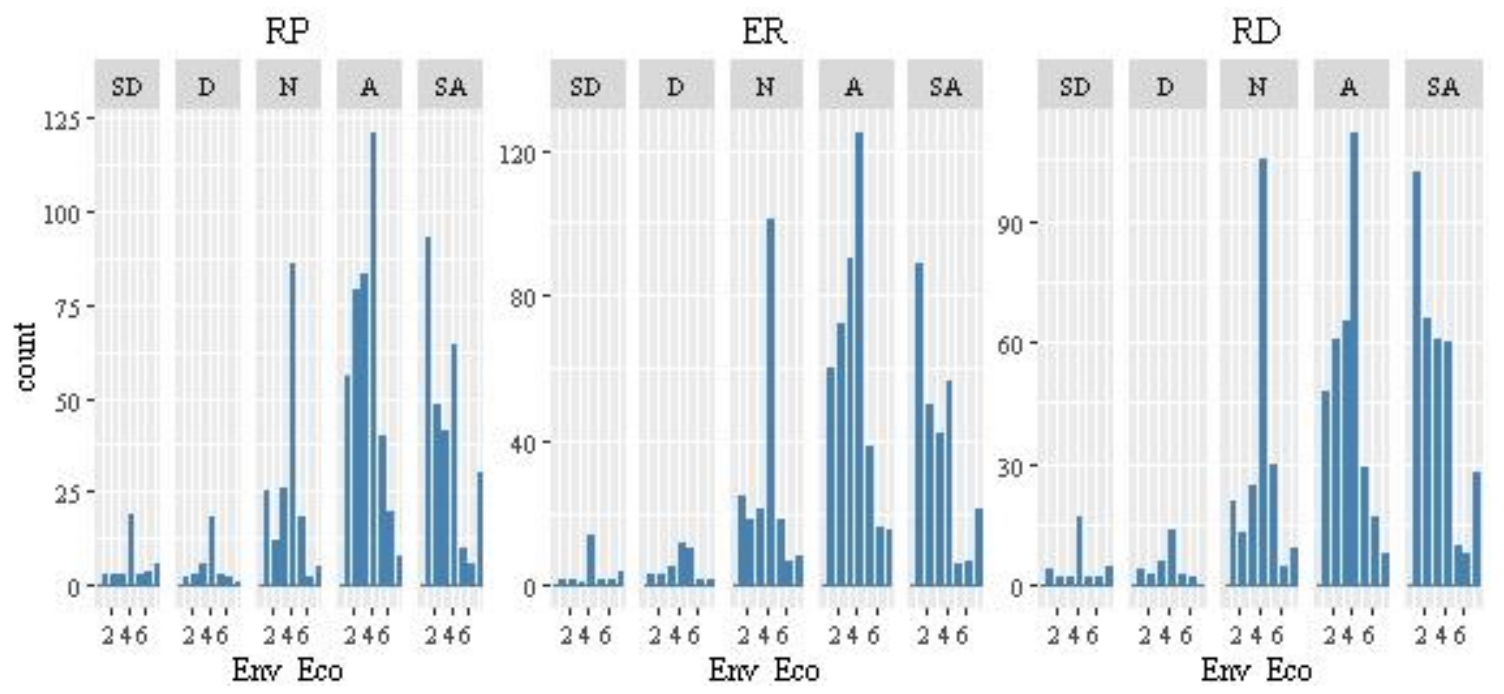

Figure 3-9. Response to Env Vs Eco question against the climate change questions

Note: The $\mathrm{Y}$ axis indicates the number for respondents (count) and the $\mathrm{X}$ axis is the categories of the responses for that variable.
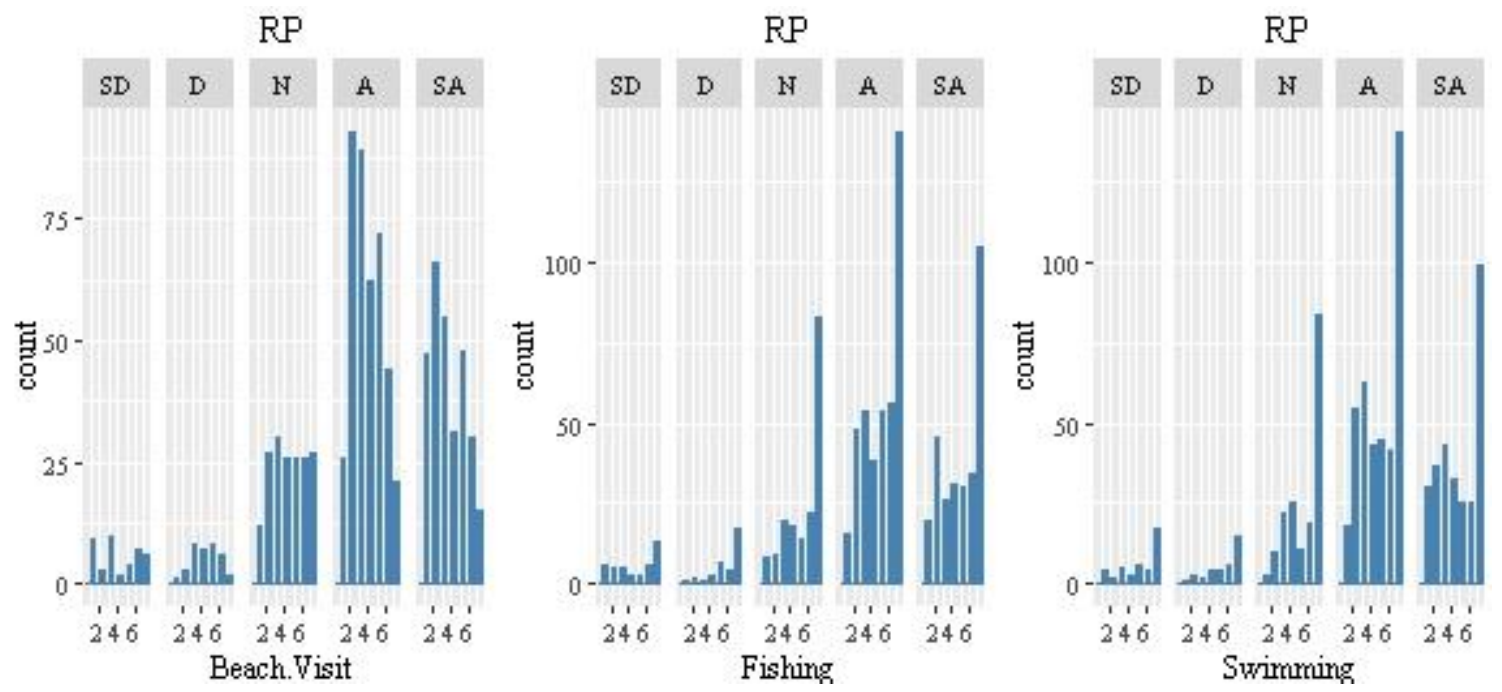

Figure 3-10. Participation in recreational activities and risk perception 

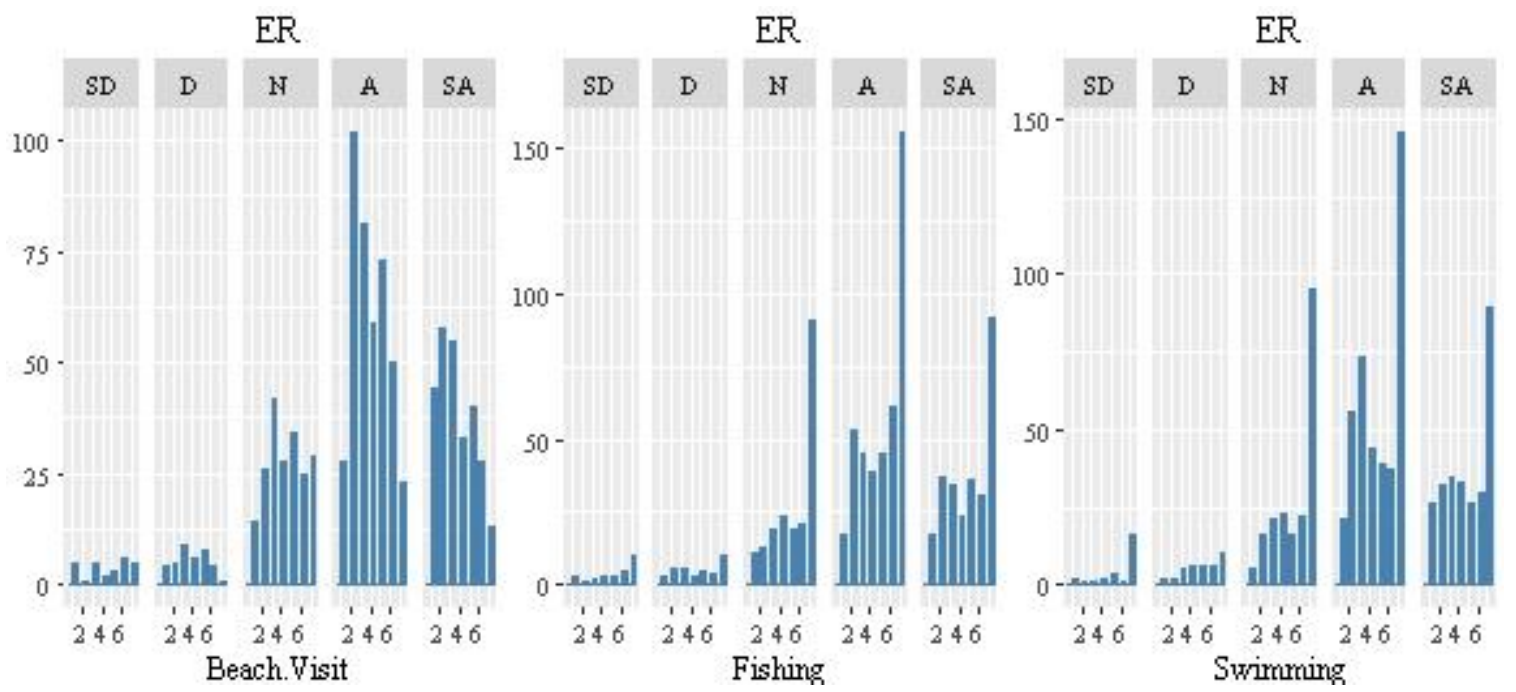

Figure 3-11. Participation in recreational activities and the Everglades restoration
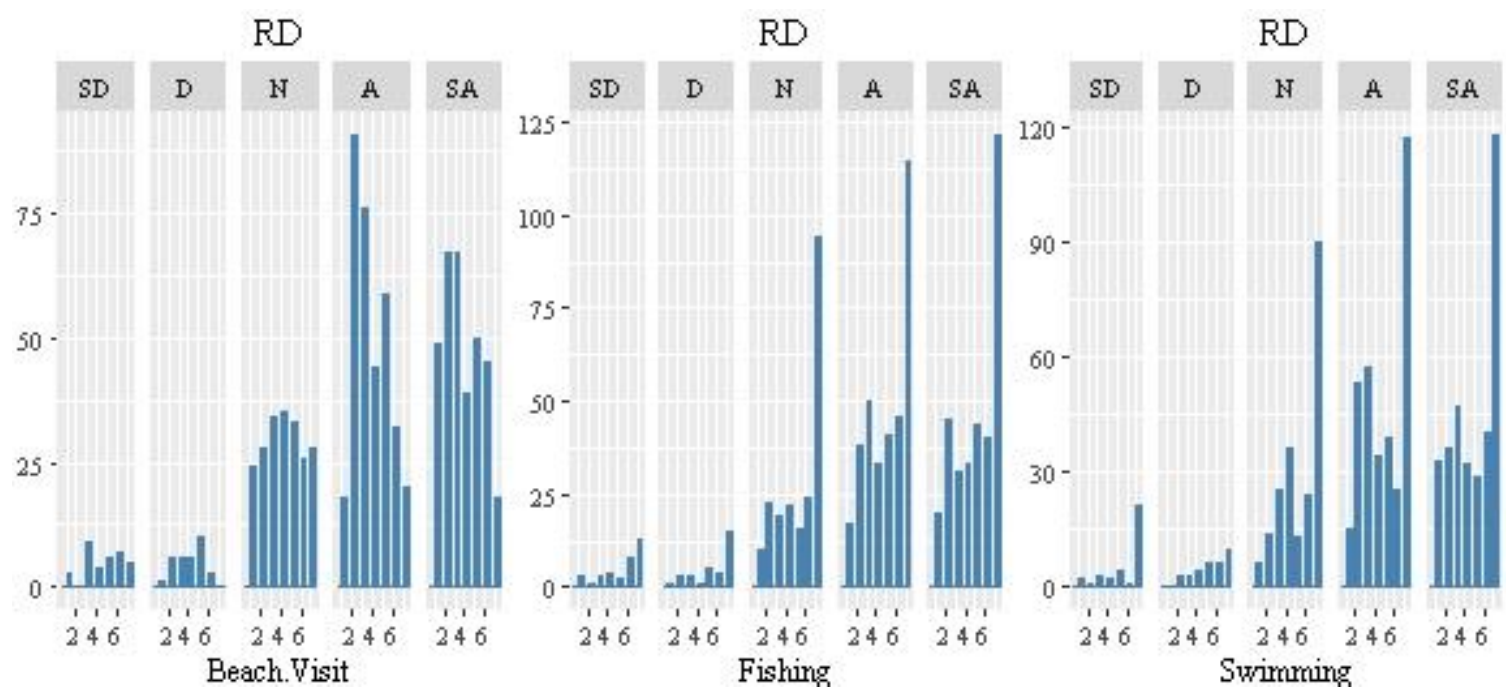

Figure 3-12. Participation in recreational activities and restriction on development

Note: The $\mathrm{Y}$ axis indicates the number for respondents (count) and the $\mathrm{X}$ axis is the categories of the responses for that variable.

Figures 3-3, 3-4 and 3-5 are a presentation of the continuous variables distance from shore and elevation versus response of the three questions. The columns represent the different response of three questions. The responses were displayed using a semi-opaque 
shade to visualize the density of responses. Darker segment indicates higher concentration of responses. The first row is the distance from shore and we can see most of the samples are in agreement with all three questions regardless of their locations. The second row represents elevation and unlike the distance, more agreement is observed with people living in low lying areas.

Figures 3-6, 3-7 and 3-8 shows responses of different management-related issues and their relationships with the three dependent variables (RP, ER, and RD). Similar to Figure 3.3, each column represents one question. Figure 3-9 shows respondents' preference for environmental protection over economic growth. As seen from the figure, people who prefers environmental protection are also in agreement with questions.

Figures 3-10, 3-11, and 3-12 show the recreational variables. The coding for these variables ranges from 1 to 7 as mentioned in Table 3-1. As seen from the three figures, people's participation in beach visits and their agreement for the three questions is positively related. However, for swimming and fishing the relationship is not straight forward.

Based on the above exploratory analysis, it is apparent that many of the variables are highly correlated with the respondents' agreement with climate change impact and possible measures of mitigation. In order to better predict this relationship, different regression models are presented in the following section. Figure 3-13 shows the spatial distribution (in terms of distance from shore and elevation from sea level) of responses for the three climate change related questions. 

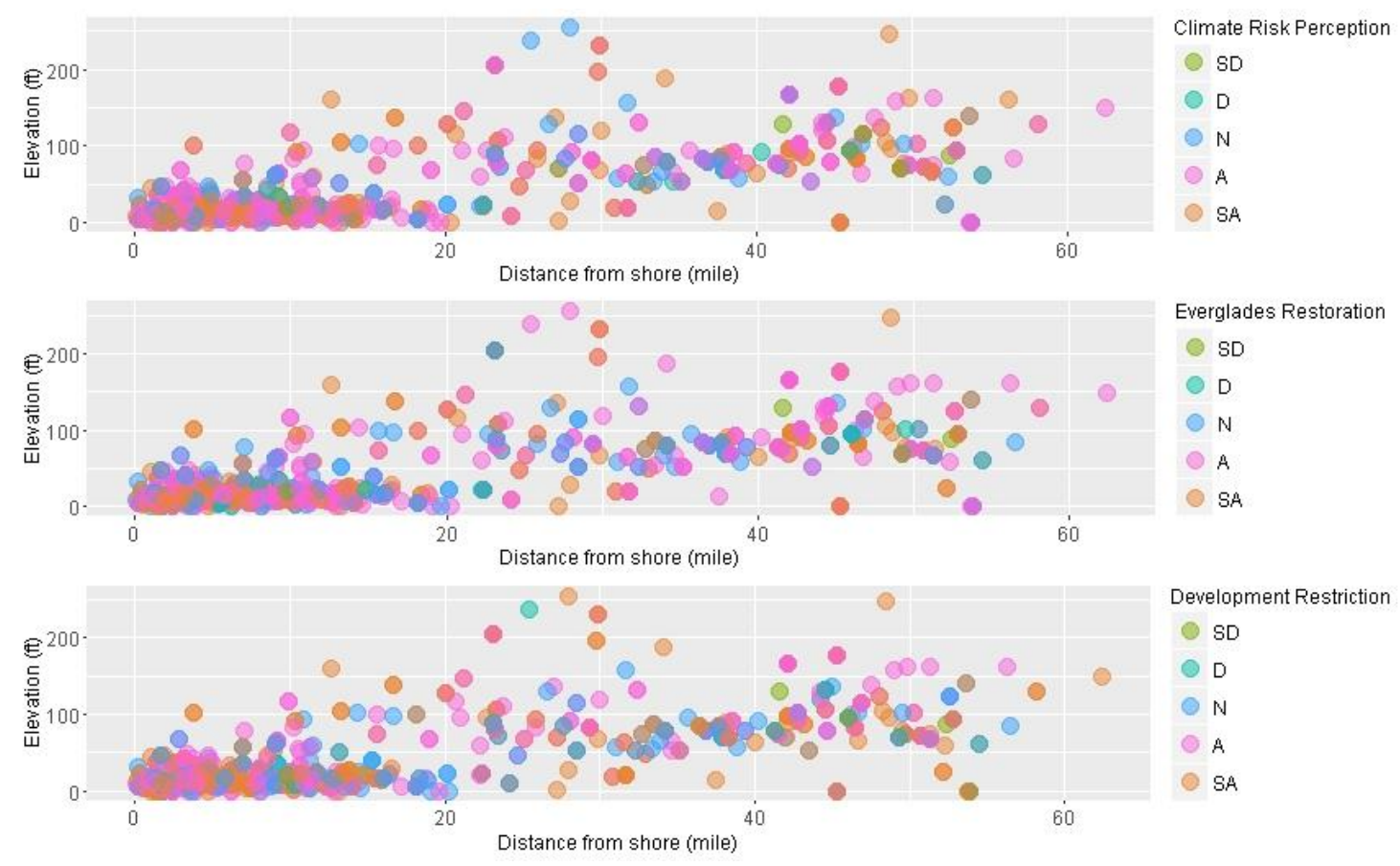

Figure 3-13. Distance from shore vs elevation and respondents' agreement level

Further analysis of the survey responses were done applying ordered logistic regression to the dataset. The results from these probability models are presented in Tables 3.4, 3.5 and 3.6. The dependent variable for the model was the response to the climate change questions. Response to these questions are categorical variables and coded on a scale of 1 to 5 where 1 being strongly disagree and 5 being strongly agree. The variables mentioned in Table 3.3 were included as predictors in the model. The predictor variables included respondents dwelling setup (i.e., distance from shore and elevation above mean sea level), their frequency of participating in different recreational activities (i.e., visiting beach, swimming, and fishing), preference for environmental protection or economic growth, how they prioritize different ecosystem services (i.e., access to recreation, urban flooding, water supply, and urban expansion) provided by Everglades in terms of various 
management scenario and different socio-demographic indicators (i.e., age, education, income, and residency in Florida). Each of the tables includes three models where the first two are the baseline models and third one includes the socio-demographic variables.

Table 3.4 reports the model of the first dependent variable, which asked if they think climate change and its impacts such as increased sea level rise pose a substantial risk to the functionality and sustainability of the ecosystem services provided by the Everglades. As discussed above, the question was intended to assess how people agree with the assumption that the Everglades is going to the affected by the changing climate. As shown in Table 3.4, several explanatory variables are highly significant in predicting this dependent variable. Env_Eco, Beach visit, Water supply, and Urban flooding all were significant, meaning that respondents' agreement about the impact of climate change in the Everglades relates to their preferences for those explanatory variables. The negative sign in the coefficient of Env_Eco, Beach visit and Swimming indicates people who prefer environmental protection or participate in those activities more frequently are more likely to agree with the predicted impact on Everglades. Moreover, from the marginal effect column, it can be seen that ranking Env_Eco higher by one unit in its scale increases the likelihood of respondents' agreement with the question by $8-9 \%$. Similarly, ranking Beach visit higher by one unit in its scale increases the likelihood of respondents' agreement with the question by $4-5 \%$ and ranking water supply higher by one unit in its scales increases by $1 \%$. The findings were consistent after adding the socio-demographic variables in the model. However, Education was found to be significant at the $10 \%$ level 
implying that people with higher education are more likely to agree with the impacts of climate change in the Everglades system.

Table 3-4. Analyzing risk perception about climate change and its impacts to the functionality and sustainability of the ecosystem services provided by the Everglades

\begin{tabular}{|c|c|c|c|c|c|c|}
\hline & \multicolumn{2}{|c|}{ Model 1} & \multicolumn{2}{|c|}{ Model 2} & \multicolumn{2}{|c|}{ Model 3} \\
\hline Variables & Coefficient & $\begin{array}{l}\text { Marginal } \\
\text { effect }\end{array}$ & Coefficient & $\begin{array}{l}\text { Marginal } \\
\text { effect }\end{array}$ & Coefficient & $\begin{array}{l}\text { Marginal } \\
\text { effect }\end{array}$ \\
\hline Elevation & $\begin{array}{l}0.001 \\
(0.826)\end{array}$ & $\begin{array}{l}0.000 \\
(0.827)\end{array}$ & $\begin{array}{l}-0.002 \\
(0.496)\end{array}$ & $\begin{array}{l}-0.000 \\
(0.495)\end{array}$ & $\begin{array}{l}-0.002 \\
(0.441)\end{array}$ & $\begin{array}{l}-0.000 \\
(0.441)\end{array}$ \\
\hline Env vs Eco & $\begin{array}{c}-0.130 \\
(0.043)^{* *}\end{array}$ & $\begin{array}{c}-0.026 \\
(0.040)^{* *}\end{array}$ & $\begin{array}{c}-0.116 \\
(0.093)^{*}\end{array}$ & $\begin{array}{c}-0.024 \\
(0.090) *\end{array}$ & $\begin{array}{c}-0.149 \\
(0.019)^{* *}\end{array}$ & $\begin{array}{c}-0.030 \\
(0.019)^{* *}\end{array}$ \\
\hline Beach visit & $\begin{array}{c}-0.207 \\
(0.000)^{* * *}\end{array}$ & $\begin{array}{c}-0.042 \\
(0.000)^{* * *} \\
\end{array}$ & $\begin{array}{c}-0.190 \\
(0.002)^{* * *}\end{array}$ & $\begin{array}{c}-0.039 \\
(0.002)^{* * *}\end{array}$ & $\begin{array}{c}-0.204 \\
(0.001)^{* * *}\end{array}$ & $\begin{array}{c}-0.041 \\
(0.001)^{* * *}\end{array}$ \\
\hline $\begin{array}{l}\text { Shore } \\
\text { distance }\end{array}$ & $\begin{array}{r}0.032 \\
(0.204) \\
\end{array}$ & $\begin{array}{r}0.006 \\
(0.204) \\
\end{array}$ & $\begin{array}{c}0.060 \\
(0.036)^{* *} \\
\end{array}$ & $\begin{array}{c}0.012 \\
(0.035)^{* *} \\
\end{array}$ & $\begin{array}{c}0.066 \\
(0.017)^{* *} \\
\end{array}$ & $\begin{array}{c}0.013 \\
(0.017)^{* *} \\
\end{array}$ \\
\hline 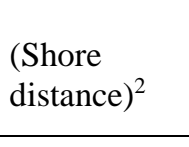 & $\begin{array}{r}-0.001 \\
(0.234) \\
\end{array}$ & $\begin{array}{r}-0.000 \\
(0.235) \\
\end{array}$ & $\begin{array}{c}-0.001 \\
(0.047)^{* *} \\
\end{array}$ & $\begin{array}{c}-0.000 \\
(0.046)^{* *}\end{array}$ & $\begin{array}{c}-0.001 \\
(0.029)^{* *}\end{array}$ & $\begin{array}{c}-0.000 \\
(0.029)^{* *} \\
\end{array}$ \\
\hline $\begin{array}{l}\text { Water } \\
\text { supplies }\end{array}$ & $\begin{array}{r}0.001 \\
(0.728) \\
\end{array}$ & $\begin{array}{r}0.000 \\
(0.728) \\
\end{array}$ & $\begin{array}{l}-0.002 \\
(0.401)\end{array}$ & $\begin{array}{l}-0.000 \\
(0.401)\end{array}$ & $\begin{array}{l}-0.002 \\
(0.334) \\
\end{array}$ & $\begin{array}{l}-0.000 \\
(0.334)\end{array}$ \\
\hline $\begin{array}{l}\text { Urban } \\
\text { Expansion }\end{array}$ & & & $\begin{array}{c}0.189 \\
(0.066)^{*}\end{array}$ & $\begin{array}{c}0.038 \\
(0.066)^{*}\end{array}$ & $\begin{array}{l}-0.040 \\
(0.687) \\
\end{array}$ & $\begin{array}{r}0.002 \\
(0.690) \\
\end{array}$ \\
\hline Urban flood & & & $\begin{array}{c}0.215 \\
(0.039)^{* *} \\
\end{array}$ & $\begin{array}{c}0.045 \\
(0.037)^{* *} \\
\end{array}$ & $\begin{array}{c}0.213 \\
(0.036)^{* *} \\
\end{array}$ & $\begin{array}{c}0.043 \\
(0.036)^{* *} \\
\end{array}$ \\
\hline Income & & & & & $\begin{array}{l}-0.008 \\
(0.828) \\
\end{array}$ & $\begin{array}{l}-0.002 \\
(0.828)\end{array}$ \\
\hline
\end{tabular}




\begin{tabular}{|c|c|c|c|c|c|c|}
\hline & \multicolumn{2}{|c|}{ Model 1} & \multicolumn{2}{|c|}{ Model 2} & \multicolumn{2}{|c|}{ Model 3} \\
\hline Variables & Coefficient & $\begin{array}{l}\text { Marginal } \\
\text { effect }\end{array}$ & Coefficient & $\begin{array}{l}\text { Marginal } \\
\text { effect }\end{array}$ & Coefficient & $\begin{array}{l}\text { Marginal } \\
\text { effect }\end{array}$ \\
\hline Education & & & & & $\begin{array}{r}0.115 \\
(0.203)\end{array}$ & $\begin{array}{r}0.023 \\
(0.203)\end{array}$ \\
\hline Residency & & & & & $\begin{array}{r}0.008 \\
(0.277) \\
\end{array}$ & $\begin{array}{r}0.002 \\
(0.277) \\
\end{array}$ \\
\hline Age & & & & & $\begin{array}{r}0.000 \\
(0.948) \\
\end{array}$ & $\begin{array}{r}0.000 \\
(0.948) \\
\end{array}$ \\
\hline Gender & & & & & $\begin{array}{r}0.196 \\
(0.338) \\
\end{array}$ & $\begin{array}{r}0.040 \\
(0.338) \\
\end{array}$ \\
\hline Env_degree & & & & & $\begin{array}{c}-1.190 \\
(0.008)^{* * *} \\
\end{array}$ & $\begin{array}{c}-0.240 \\
(0.008)^{* * * *}\end{array}$ \\
\hline Observation & 455 & & 385 & & 377 & \\
\hline LR chi ${ }^{2}$ & 0.003 & & 0.000 & & 0.000 & \\
\hline Prob > chi ${ }^{2}$ & 19.95 & & 33.45 & & 52.33 & \\
\hline $\begin{array}{l}\text { Log- } \\
\text { likelihood }\end{array}$ & -595.5 & & -494.1 & & -477.7 & \\
\hline
\end{tabular}

Notes: ***,**,* imply significance at $1 \%, 5 \%$, and $10 \%$ levels respectively; P-values are in parentheses.

Likewise, Table 3.5 reports the model of the second dependent variable that inquired if a respondent thinks we need to be more aggressive about the Everglades restoration due to saltwater intrusion caused by sea level rise. Ordered logistic regression was used to assess the relationship with different independent variables with this statement. As shown in the table, elevation, Env_Eco, Beach visit, and Urban flooding variables are significant for these models. The positive sign in the elevation variable indicates that people who live in low lying areas are more likely to agree with the question. Similarly, the significance 
level of $1 \%$ for Evn_Eco, beach visit, and Urban flooding variables indicates that respondents in agreement with those variables are very likely to agree with the question. Additionally, the marginal effect column indicates that, ranking Beach visit higher by one unit in its scale increases the likelihood of respondents' agreement with the question by $3 \%$ and for Urban flooding $1 \%$.

Table 3-5. Analyzing household risk perception on importance of the Everglades restoration considering sea level rise and salt water intrusion

\begin{tabular}{|c|c|c|c|c|c|c|}
\hline & \multicolumn{2}{|c|}{ Model 1} & \multicolumn{2}{|c|}{ Model 2} & \multicolumn{2}{|c|}{ Model 3} \\
\hline Variables & Coefficient & $\begin{array}{l}\text { Marginal } \\
\text { effect }\end{array}$ & Coefficient & $\begin{array}{l}\text { Marginal } \\
\text { effect }\end{array}$ & Coefficient & $\begin{array}{l}\text { Marginal } \\
\text { effect }\end{array}$ \\
\hline Elevation & $\begin{array}{l}0.004 \\
(0.073)^{*}\end{array}$ & $\begin{array}{c}-0.000 \\
(0.090)^{*}\end{array}$ & $\begin{array}{l}0.004 \\
(0.075)^{*}\end{array}$ & $\begin{array}{l}-0.000 \\
(0.092)^{*}\end{array}$ & $\begin{array}{l}0.004 \\
(0.057)^{*}\end{array}$ & $\begin{array}{l}-0.000 \\
(0.073)^{*}\end{array}$ \\
\hline Env vs Eco & $\begin{array}{l}-0.282 \\
(0.000)^{* * *}\end{array}$ & $\begin{array}{l}0.006 \\
(0.000)^{* * *}\end{array}$ & $\begin{array}{l}-0.277 \\
(0.000)^{* * *}\end{array}$ & $\begin{array}{l}0.006 \\
(0.000)^{* * *}\end{array}$ & $\begin{array}{l}-0.269 \\
(0.000)^{* * *}\end{array}$ & $\begin{array}{l}0.006 \\
(0.000) * * *\end{array}$ \\
\hline Beach visit & $\begin{array}{l}-0.161 \\
(0.000)^{* * *}\end{array}$ & $\begin{array}{l}0.004 \\
(0.001)^{* * *}\end{array}$ & $\begin{array}{l}-0.174 \\
(0.000)^{* * *}\end{array}$ & $\begin{array}{l}0.004 \\
(0.002) * * *\end{array}$ & $\begin{array}{l}-0.183 \\
(0.000)^{* * *}\end{array}$ & $\begin{array}{l}0.004 \\
(0.001)^{* * *}\end{array}$ \\
\hline Shore distance & $\begin{array}{l}-0.022 \\
(0.229)\end{array}$ & $\begin{array}{l}0.001 \\
(0.240)\end{array}$ & $\begin{array}{l}-0.020 \\
(0.282)\end{array}$ & $\begin{array}{l}0.000 \\
(0.291)\end{array}$ & $\begin{array}{l}-0.022 \\
(0.240)\end{array}$ & $\begin{array}{c}0.000 \\
(0.251)\end{array}$ \\
\hline 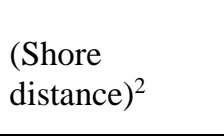 & $\begin{array}{l}0.000 \\
(0.297)\end{array}$ & $\begin{array}{l}-0.000 \\
(0.306)\end{array}$ & $\begin{array}{l}0.000 \\
(0.343)\end{array}$ & $\begin{array}{l}-0.000 \\
(0.351)\end{array}$ & $\begin{array}{l}0.000 \\
(0.273)\end{array}$ & $\begin{array}{l}-0.000 \\
(0.283)\end{array}$ \\
\hline $\begin{array}{l}\text { Recreation } \\
\text { access }\end{array}$ & $\begin{array}{l}0.107 \\
(0.097)^{*}\end{array}$ & $\begin{array}{l}-0.002 \\
(0.113)\end{array}$ & $\begin{array}{l}0.063 \\
(0.369)\end{array}$ & $\begin{array}{l}-0.001 \\
(0.376)\end{array}$ & $\begin{array}{l}0.121 \\
(0.070)^{*}\end{array}$ & $\begin{array}{l}-0.003 \\
(0.086)^{*}\end{array}$ \\
\hline Urban flood & $\begin{array}{l}0.485 \\
(0.000)^{* * *}\end{array}$ & $\begin{array}{l}-0.011 \\
(0.000)^{* * *}\end{array}$ & $\begin{array}{c}0.390 \\
(0.000)^{* * *}\end{array}$ & $\begin{array}{l}-0.009 \\
(0.000)^{* * *}\end{array}$ & $\begin{array}{l}0.468 \\
(0.000)^{* * *}\end{array}$ & $\begin{array}{l}-0.010 \\
(0.000)^{* * *}\end{array}$ \\
\hline
\end{tabular}




\begin{tabular}{|c|c|c|c|c|c|c|}
\hline & \multicolumn{2}{|c|}{ Model 1} & \multicolumn{2}{|c|}{ Model 2} & \multicolumn{2}{|c|}{ Model 3} \\
\hline Variables & Coefficient & $\begin{array}{l}\text { Marginal } \\
\text { effect }\end{array}$ & Coefficient & $\begin{array}{l}\text { Marginal } \\
\text { effect }\end{array}$ & Coefficient & $\begin{array}{l}\text { Marginal } \\
\text { effect }\end{array}$ \\
\hline Income & & & & & $\begin{array}{l}0.020 \\
(0.400)\end{array}$ & $\begin{array}{l}-0.000 \\
(0.407)\end{array}$ \\
\hline Education & & & & & $\begin{array}{l}0.006 \\
(0.934)\end{array}$ & $\begin{array}{l}-0.000 \\
(0.934)\end{array}$ \\
\hline Residency & & & & & $\begin{array}{l}0.003 \\
(0.551)\end{array}$ & $\begin{array}{l}-0.000 \\
(0.553)\end{array}$ \\
\hline Age & & & & & $\begin{array}{l}0.016 \\
(0.001)^{* * *}\end{array}$ & $\begin{array}{l}-0.000 \\
(0.004)^{* * *}\end{array}$ \\
\hline Gender & & & & & $\begin{array}{l}0.010 \\
(0.949) \\
\end{array}$ & $\begin{array}{l}-0.000 \\
(0.949)\end{array}$ \\
\hline Env_degree & & & & & $\begin{array}{l}-0.339 \\
(0.265)\end{array}$ & $\begin{array}{l}0.007 \\
(0.275)\end{array}$ \\
\hline Water supplies & & & $\begin{array}{l}0.276 \\
(0.005)^{* * *}\end{array}$ & $\begin{array}{l}-0.006 \\
(0.013)^{* *}\end{array}$ & & \\
\hline Fishing & & & $\begin{array}{l}0.018 \\
(0.652) \\
\end{array}$ & $\begin{array}{l}-0.000 \\
(0.654) \\
\end{array}$ & & \\
\hline Observation & 760 & & 742 & & 745 & \\
\hline LR chi $^{2}$ & 0 & & 0 & & 0 & \\
\hline Prob > chi ${ }^{2}$ & 130.5 & & 135.4 & & 147.4 & \\
\hline Log-likelihood & -915.4 & & -891.7 & & -887.9 & \\
\hline
\end{tabular}

Notes: ***,**,* imply significance at $1 \%, 5 \%$, and $10 \%$ levels respectively; P-values are in parentheses. 
Finally, Table 3.6 presents the three models for the respondents' agreement with the question regarding whether we should restrict further development in low lying coastal areas in Florida due the anticipated risk of sea level rise. Similar to the above two questions, ordered logistic regression was applied to develop these models. For this model, Elevation, Env_Eco, Beach visit, Urban flooding and urban expansion were significant at the $1 \%$ level. Additionally, the marginal effect column indicates that, ranking Urban flooding higher by one unit in its scale increases the likelihood of respondents' agreement with the question by $1 \%$ and for Urban expansion (model 2) $1 \%$.

Table 3-6. Analyzing household preference for people's perception on restricting further development in low lying coastal areas

\begin{tabular}{|c|c|c|c|c|c|c|}
\hline \multirow[b]{2}{*}{ Variables } & \multicolumn{2}{|l|}{ Model 1} & \multicolumn{2}{|l|}{ Model 2} & \multicolumn{2}{|l|}{ Model 3} \\
\hline & Coefficient & $\begin{array}{l}\text { Marginal } \\
\text { effect }\end{array}$ & Coefficient & $\begin{array}{l}\text { Marginal } \\
\text { effect }\end{array}$ & Coefficient & $\begin{array}{l}\text { Marginal } \\
\text { effect }\end{array}$ \\
\hline Elevation & $\begin{array}{l}0.005 \\
(0.010)^{* * * *}\end{array}$ & $\begin{array}{l}-0.000 \\
(0.017)^{* *}\end{array}$ & $\begin{array}{l}0.005 \\
(0.019)^{* *}\end{array}$ & $\begin{array}{c}-0.000 \\
(0.029) * *\end{array}$ & $\begin{array}{l}0.004 \\
(0.091)^{*}\end{array}$ & $\begin{array}{l}-0.000 \\
(0.108)\end{array}$ \\
\hline Env vs Eco & $\begin{array}{l}-0.284 \\
(0.000)^{* * *}\end{array}$ & $\begin{array}{l}0.008 \\
(0.000)^{* * *}\end{array}$ & $\begin{array}{l}-0.275 \\
(0.000)^{* * *}\end{array}$ & $\begin{array}{l}0.008 \\
(0.000)^{* * * *}\end{array}$ & $\begin{array}{l}-0.252 \\
(0.000)^{* * *}\end{array}$ & $\begin{array}{l}0.006 \\
(0.000) * * *\end{array}$ \\
\hline Beach visit & $\begin{array}{l}-0.123 \\
(0.002)^{* * * *}\end{array}$ & $\begin{array}{l}0.004 \\
(0.005)^{* * * *}\end{array}$ & $\begin{array}{l}-0.128 \\
(0.001)^{* * *}\end{array}$ & $\begin{array}{l}0.004 \\
(0.004)^{* * *} \\
\end{array}$ & $\begin{array}{l}-0.191 \\
(0.000)^{* * *}\end{array}$ & $\begin{array}{l}0.004 \\
(0.001)^{* * *}\end{array}$ \\
\hline Shore distance & $\begin{array}{r}-0.019 \\
(0.321) \\
\end{array}$ & $\begin{array}{r}0.001 \\
(0.327) \\
\end{array}$ & $\begin{array}{l}-0.011 \\
(0.567) \\
\end{array}$ & $\begin{array}{r}0.000 \\
(0.569) \\
\end{array}$ & $\begin{array}{l}-0.018 \\
(0.355) \\
\end{array}$ & $\begin{array}{l}0.000 \\
(0.363) \\
\end{array}$ \\
\hline$(\text { Shore distance })^{2}$ & $\begin{array}{l}0.000 \\
(0.506)\end{array}$ & $\begin{array}{l}-0.000 \\
(0.508)\end{array}$ & $\begin{array}{l}0.000 \\
(0.831)\end{array}$ & $\begin{array}{l}-0.000 \\
(0.831)\end{array}$ & $\begin{array}{l}0.000 \\
(0.400)\end{array}$ & $\begin{array}{l}-0.000 \\
(0.406)\end{array}$ \\
\hline Recreation access & 0.033 & -0.001 & -0.090 & 0.003 & 0.025 & -0.001 \\
\hline
\end{tabular}




\begin{tabular}{|c|c|c|c|c|c|c|}
\hline \multirow[b]{2}{*}{ Variables } & \multicolumn{2}{|l|}{ Model 1} & \multicolumn{2}{|l|}{ Model 2} & \multicolumn{2}{|l|}{ Model 3} \\
\hline & Coefficient & $\begin{array}{l}\text { Marginal } \\
\text { effect }\end{array}$ & Coefficient & $\begin{array}{l}\text { Marginal } \\
\text { effect }\end{array}$ & Coefficient & $\begin{array}{l}\text { Marginal } \\
\text { effect }\end{array}$ \\
\hline & $(0.604)$ & $(0.605)$ & $(0.202)$ & $(0.212)$ & $(0.734)$ & $(0.735)$ \\
\hline Urban flood & $\begin{array}{l}0.393 \\
(0.000)^{* * *}\end{array}$ & $\begin{array}{l}-0.012 \\
(0.000)^{* * *}\end{array}$ & $\begin{array}{l}0.278 \\
(0.000)^{* * *}\end{array}$ & $\begin{array}{l}-0.008 \\
(0.002) * * *\end{array}$ & $\begin{array}{l}0.369 \\
(0.000)^{* * *}\end{array}$ & $\begin{array}{l}-0.008 \\
(0.000)^{* * *}\end{array}$ \\
\hline Urban expansion & & & $\begin{array}{l}0.354 \\
(0.000) * * *\end{array}$ & $\begin{array}{l}-0.010 \\
(0.000) * * *\end{array}$ & $\begin{array}{l}0.324 \\
(0.000) * * *\end{array}$ & $\begin{array}{l}-0.007 \\
(0.002)^{* * *}\end{array}$ \\
\hline Income & & & & & $\begin{array}{l}0.021 \\
(0.377)\end{array}$ & $\begin{array}{l}-0.000 \\
(0.384)\end{array}$ \\
\hline Education & & & & & $\begin{array}{l}-0.020 \\
(0.768)\end{array}$ & $\begin{array}{l}0.000 \\
(0.769)\end{array}$ \\
\hline Residency & & & & & $\begin{array}{l}0.002 \\
(0.715)\end{array}$ & $\begin{array}{l}-0.000 \\
(0.715)\end{array}$ \\
\hline Age & & & & & $\begin{array}{l}0.014 \\
(0.002)^{* * *}\end{array}$ & $\begin{array}{l}-0.000 \\
(0.009)^{* * *}\end{array}$ \\
\hline Gender & & & & & $\begin{array}{l}-0.036 \\
(0.809)\end{array}$ & $\begin{array}{l}0.001 \\
(0.809)\end{array}$ \\
\hline Env_degree & & & & & $\begin{array}{l}-0.208 \\
(0.498)\end{array}$ & $\begin{array}{l}0.005 \\
(0.501)\end{array}$ \\
\hline Observation & 760 & & 733 & & 718 & \\
\hline LR chi ${ }^{2}$ & 0 & & 0 & & 0 & \\
\hline Prob > chi ${ }^{2}$ & 100.8 & & 114.8 & & 155.7 & \\
\hline Log-likelihood & -939.4 & & -901.4 & & -852.8 & \\
\hline
\end{tabular}

Notes: ***, **, * imply significance at $1 \%, 5 \%$, and $10 \%$ levels respectively; P-values are in parentheses. 


\subsection{Conclusion}

For a robust decision making process relating to climate change and sea level rise, it is crucial to incorporate the general public's opinion in the process (Chilvers et al., 2014). Particularly in the context of the Everglades, where the system was altered to enhance some services for those living in low-lying areas and those alterations presently continue serving as a significant source of economic growth (Kranzer, 2002), public perception on climate change consequences and potential ramifications are very important for a socially accepted decision making process. In our first three models, we see that people who are more concerned about environmental protection and care more about different services (e.g., water supply, urban flooding) are more likely to agree with the fact that climate change imposes substantial risk to the services of the Everglades compared to distance from the shore or elevation of the household. This finding is particularly important because the general notion is that people who live close to the shore areas are the people who are more exposed to climatic alterations and therefore would be more likely to agree with the climate change facts. However, we did not see any significant relationship in these cases. In the second set of models we see that together with environmentally concerned people, people who take part in recreational activities and people living in low lying areas are also more likely to agree that due to climate change we need to be more aggressive about restoring the Everglades. Similarly, in the third set of models, people who live in low lying areas are more likely to agree that we should stop further development in lower elevation areas. In general, the findings provide us some ideas about people's perceptions on possible consequences of climate change and their attitude 
about possible mitigation and adaptation approaches. This useful insight about people's understanding and opinions may assist decision makers to design potential strategies to cope with climate change in this region. 


\section{DISCUSSION AND CONCLUSION}

The Everglades offers numerous ES to the people living in Florida. Functionality of this unique ecosystem largely depends on its water distribution. Humans have altered the quality and quantity of water to enhance economic gain and by doing so have made the system sensitive and affected its productivity. As the population in Florida increases, the dependency on the Everglades is also escalating to provide support to the new residents. The CERP, one of the largest environmental restoration initiatives approved by the U.S. Congress, aims to restore, protect, and preserve the water resources of central and southern Florida without affecting economic productivity. Once implemented to its full extent, the plan will try to restore the central Everglades closer to its historic condition. Doing so would affect the ES, especially altering the spatial distribution of the services.

Decision makers would have an edge by understanding public preferences for different ES and its distribution over the entire state. This insight will help them implement the CERP while avoiding local conflicts. The first part of the research estimated public preference for four different groups of ES. Mapping of public preference for those attribute sets provides insight into how people in different part of the state prioritize the ES and their views on the importance of restoration.

The second part presented three different sets of models on the public's understanding and attitude on climate change impact in the study region. As discussed in Chapter 3, people living in low-lying areas are more likely to agree that climate change is going to affect the ES and that we need to be more aggressive to restore the Everglades. The 
models also showed a strong relationship between public preference for the environment or frequency of participation in outdoor recreational activities and their agreement to the climate change risk and preference for mitigation.

As mentioned before, the restoration project, the CERP, would attempt to bring the central Everglades back closer to its historic condition. This transformation is expected to improve many of the ES provided by the Everglades, however, it may also reduce few of them. Findings from Chapter 2 suggested that public preference for the Everglades restoration varies depending on the type of ES. For the same respondent, the choice of restoration changed as the ES changed from one set of choice cards to another. It is possible that the same person has opted for the highest level of restoration for a choice card (representing one set of ES) and preferred no restoration for the next card (representing another set of choice card). Although, we saw the variation of public preference for the four different choice card sets (Figure 2-10 to Figure 2-14), the prevalence of color green and blue in the preference maps indicates that in general, the public prefers restoration of the Everglades. Dependency or connection to an ES might have dictated public preference while selecting a specific restoration plan, but the common trend was more toward restoring the Everglades. This trend is also reflected in Chapter 3, when the same population was asked about their perception of climate change and its impact on the Everglades. From the three sets of models (Table 3-4, Table 3-5 and Table 3-6), in almost every case, environmentally concerned people were more likely to agree with the climate change risk perception questions. 
Additionally, one conclusion from Chapter 2 was that ES dictates people's preference for ecosystem restoration. This proposition was confirmed by the models we developed in Chapter 3. Particularly, Table 3-6 showed that people who perceived urban expansion and urban flooding was important are more likely to consider that we need to restrict further development in low lying areas due to climate change and sea level rise. It reconfirms that ES (in this case urban expansion and urban flooding) influences people's decision making for restoration (in this case restriction on development in low lying areas). While future studies focusing on particular ES can further indicate the causes and significance of different factors influencing public preference for Everglades restoration, the present study highlights the fact that people in Florida have a varying preference for Everglades restoration, and the preference is ES-specific and spatially heterogeneous.

In conclusion, implementation of the CERP would change the ES we receive from the Everglades. On the other hand, climate change and sea level rise are a major threat to the Everglades that would also reduce and alter the ES. Understanding public preference for these ES can help better manage the execution of the CERP. Additionally, the public's views about climate change can also help decision makers to prioritize during the implementation of the restoration plan. 


\section{REFERENCE}

Aumen, N.G., Havens, K.E., Best, G.R., Berry, L., 2015. Predicting Ecological Responses of the Florida Everglades to Possible Future Climate Scenarios: Introduction. Environ. Manage. 55, 741-748. doi:10.1007/s00267-014-0439-z

Berbel, J., Brouwer, R., Martin-Ortega, J., 2010. Spatial Preference Heterogeneity : A Choice Experiment. Land Econ. 86, 552-568. doi:10.1353/lde.2010.0045

Borsuk, M., Clemen, R., Maguire, L., Reckhow, K., 2001. Stakeholder Values and Scientific Modeling in the Neuse River Watershed. Gr. Decis. Negot. 10, 355-373. doi:10.1023/A:1011231801266

Campbell, D., Hutchinson, W.G., Scarpa, R., 2009. Using choice experiments to explore the spatial distribution of willingness to pay for rural landscape improvements. Environ. Plan. A 41, 97-111. doi:10.1068/a4038

Catano, C.P., Romañach, S.S., Beerens, J.M., Pearlstine, L.G., Brandt, L. a., Hart, K.M., Mazzotti, F.J., Trexler, J.C., 2014. Using Scenario Planning to Evaluate the Impacts of Climate Change on Wildlife Populations and Communities in the Florida Everglades. Environ. Manage. 55, 807-823. doi:10.1007/s00267-014-0397-5

Chilvers, J., Lorenzoni, I., Terry, G., Buckley, P., Pinnegar, J.K., Gelcich, S., 2014. Public engagement with marine climate change issues: (Re)framings, understandings and responses. Glob. Environ. Chang. 29, 165-179. doi:10.1016/j.gloenvcha.2014.09.006

Clarke, A.L., Dalrymple, G.H., 2003. \$ 7 . 8 Billion for Everglades Restoration : Why Do Environmentalists Look so Worried? Popul. Environ. 24, 541-569.

ESRI, 2001. ArcGIS TM Geostatistical Analyst : Statistical Tools for Data Exploration, Modeling, and Advanced Surface Generation, White Paper, ESRI White Paper.

ESRI, 2016. Introduction to Geostatistical Analyst [WWW Document]. Environ. Syst. Res. Inst. URL http://desktop.arcgis.com/en/arcmap/latest/extensions/geostatisticalanalyst/what-is-geostatistics-.htm (accessed 5.6.16).

Estenoz, S., Bush, E., 2015. Everglades Restoration Science and Decision-Making in the Face of Climate Change: A Management Perspective. Environ. Manage. 55, 876-883. doi:10.1007/s00267-015-0452-x

Flugman, E., Mozumder, P., Randhir, T., 2012. Facilitating adaptation to global climate change: Perspectives from experts and decision makers serving the Florida Keys. Clim. Change 112, 1015-1035. doi:10.1007/s10584-011-0256-9 
Godfrey, M.C., Catton, T., 2011. River of Interests: Water Management in South Florida and the Everglades, 1948-2010. Historical Research Associates, Inc.

Gunderson, L., Light, S.S., 2006. Adaptive management and adaptive governance in the everglades ecosystem. Policy Sci. 39, 323-334. doi:10.1007/s11077-006-9027-2

Havens, K.E., Steinman, A.D., 2013. Ecological Responses of a Large Shallow Lake (Okeechobee, Florida) to Climate Change and Potential Future Hydrologic Regimes. Environ. Manage. 55, 763-775. doi:10.1007/s00267-013-0189-3

Hosmer, D.W., Lemeshow, S., Sturdivant, R.X., 2013. Applied Logistic Regression (3rd Edition). John Wiley \& Sons, New York, NY, USA.

Isaaks, E.H., Srivastava, M.R., 1961. Applied geostatistics, Oxford University Press. Oxford University Press, New York.

Kleinbaum, D.G., Klein, M., 2010. Logistic Regression: A self-learning text, Third Edit. ed. Springer Publishers New York, Inc., New York.

Kranzer, B., 2002. The Human Context for Everglades Restoration : The South Florida Case Study, in: Karin, M.K. (Ed.), Publication Series: Human Population and Freshwater Resources. Yale School Forestry \& Environmental Studies, pp. 25-59.

Krivoruchko, K., 2012. Empirical Bayesian Kriging Implemented in ArcGIS Geostatistical Analyst. ArcUser Fall 2012 Ed. 6-10.

Larsen, L., Aumen, N., Bernhardt, C., Engel, V., Givnish, T., Hagerthey, S., Harvey, J., Leonard, L., McCormick, P., Mcvoy, C., Noe, G., Nungesser, M., Rutchey, K., Sklar, F., Troxler, T., Volin, J., Willard, D., 2011. Recent and Historic Drivers of Landscape Change in the Everglades Ridge, Slough, and Tree Island Mosaic. Crit. Rev. Environ. Sci. Technol. 41, 344-381. doi:10.1080/10643389.2010.531219

McCormick, B., Clement, R., Fischer, D., Lindsay, M., Watson, R., 2010. Measuring the Economic Benefits of America's Everglades Restoration. A Report Prepared for The Everglades Foundation, Palmetto Bay, Florida 33157.

Milon, J.W., Hodges, A.W., Rimal, A., Kiker, C.F., Casey, F., 1999. Public Preferences and Economic Values for the Restoration of the Everglades/South Florida Ecosystem., Economic Report 99-1. Food and Resource Economics Department, University of Florida,Gainesville, Florida.

Mozumder, P., Flugman, E., Randhir, T., 2011. Adaptation behavior in the face of global climate change: Survey responses from experts and decision makers serving the Florida Keys. Ocean Coast. Manag. 54, 37-44. doi:10.1016/j.ocecoaman.2010.10.008

National Research Council, 2014. Progress Toward Restoring the Everglades : The Fifth Biennial Review. National Academies Press, Washington D.C. 
Nungesser, M., Saunders, C., Coronado-Molina, C., Obeysekera, J., Johnson, J., McVoy, C., Benscoter, B., 2014. Potential Effects of Climate Change on Florida's Everglades.

Environ. Manage. 55, 824-835. doi:10.1007/s00267-014-0417-5

Obeysekera, J., Barnes, J., Nungesser, M., 2014. Climate Sensitivity Runs and Regional Hydrologic Modeling for Predicting the Response of the Greater Florida Everglades Ecosystem to Climate Change. Environ. Manage. 55, 749-762. doi:10.1007/s00267-0140315-X

Orem, W., Newman, S., Osborne, T.Z., Reddy, K.R., 2014. Projecting Changes in Everglades Soil Biogeochemistry for Carbon and Other Key Elements, to Possible 2060 Climate and Hydrologic Scenarios. Environ. Manage. 55, 776-798. doi:10.1007/s00267014-0381-0

Perry, W., 2004. Elements of South Florida's comprehensive everglades restoration plan. Ecotoxicology 13, 185-193. doi:10.1023/B:ECTX.0000023564.10311.4a

Qualtrics, 2005. Survey Platform - Understand Your Data|Qualtrics [WWW Document]. Surv. Platf. URL https://www.qualtrics.com/support/survey-platform/data-and-analysismodule/data/download-data/understanding-your-dataset/ (accessed 6.29.16).

Saha, A.K., Saha, S., Sadle, J., Jiang, J., Ross, M.S., Price, R.M., Sternberg, L.S.L.O., Wendelberger, K.S., 2011. Sea level rise and South Florida coastal forests. Clim. Change 107, 81-108. doi:10.1007/s10584-011-0082-0

Schwartz, K.Z.S., 2013. Panther politics: Neoliberalizing nature in Southwest Florida. Environ. Plan. A 45, 2323-2343. doi:10.1068/a45294

Seeteram, N.A., 2014. Valuation of Ecosystem Services for Environmental Decision Making in South Florida. MS thesis, Department of Earthe and Environment, Florida International University.

Tam, J., McDaniels, T.L., 2013. Understanding individual risk perceptions and preferences for climate change adaptations in biological conservation. Environ. Sci. Policy 27, 114-123. doi:10.1016/j.envsci.2012.12.004

The Nature Conservancy, 2009. Economic Benefits of Land Conservation A Case for Florida Forever. The Nature Conservancy, Tallahassee Field Office, FL.

Tobler, W., 1970. A Computer Movie Simulating Urban Growth in the Detroit Region. Econ. Geogr. 46, 234-240.

Valk, Arnold G, V. Der, Volin, J.C., Wetzel, P.R., 2015. Predicted Changes in Interannual Water-Level Fluctuations Due to Climate Change and Its Implications for the Vegetation of the Florida Everglades. Environ. Manage. 55, 799-806.

doi:10.1007/s00267-014-0434-4 
Zhang, K., Dittmar, J., Ross, M., Bergh, C., 2011. Assessment of sea level rise impacts on human population and real property in the Florida Keys. Clim. Change 107, 129-146. doi:10.1007/s10584-011-0080-2 


\section{APPENDIX}

\begin{tabular}{|c|c|c|c|c|c|c|c|c|c|c|c|c|c|c|c|c|c|}
\hline & 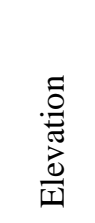 & 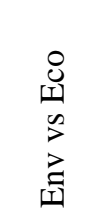 & 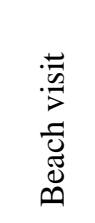 & 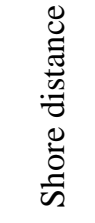 & 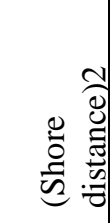 & 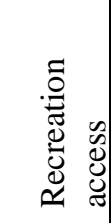 & 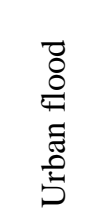 & 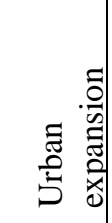 & 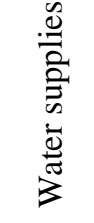 & 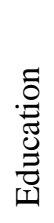 & $\begin{array}{l}\mathscr{\Xi} \\
\stackrel{0}{\Xi} \\
.\end{array}$ & $\stackrel{\infty}{<}$ & 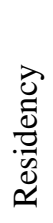 & $\frac{\overline{0}}{\overline{0}}$ & 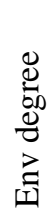 & 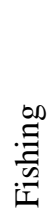 & 告 \\
\hline Elevation & 1.000 & & & & & & & & & & & & & & & & \\
\hline Env vs Eco & 0.012 & 1.000 & & & & & & & & & & & & & & & \\
\hline Beach visit & 0.109 & 0.056 & 1.000 & & & & & & & & & & & & & & \\
\hline $\begin{array}{r}\text { Shore } \\
\text { distance }\end{array}$ & 0.694 & 0.032 & 0.130 & 1.000 & & & & & & & & & & & & & \\
\hline $\begin{array}{r}\text { (Shore } \\
\text { distance)2 }\end{array}$ & 0.636 & 0.034 & 0.116 & 0.970 & 1.000 & & & & & & & & & & & & \\
\hline $\begin{array}{r}\text { Recreation } \\
\text { access }\end{array}$ & 0.077 & $\begin{array}{l}- \\
0.050\end{array}$ & $\begin{array}{l}- \\
0.078\end{array}$ & 0.054 & 0.047 & 1.000 & & & & & & & & & & & \\
\hline $\begin{array}{r}\text { Urban } \\
\text { flood }\end{array}$ & 0.002 & $\begin{array}{l}- \\
0.071\end{array}$ & $\begin{array}{l}- \\
0.046\end{array}$ & 0.031 & 0.028 & 0.335 & 1.000 & & & & & & & & & & \\
\hline $\begin{array}{r}\text { Urban } \\
\text { expansion }\end{array}$ & 0.058 & $\begin{array}{l}- \\
0.093\end{array}$ & $\begin{array}{l}- \\
0.007\end{array}$ & 0.056 & 0.063 & 0.464 & 0.430 & 1.000 & & & & & & & & & \\
\hline $\begin{array}{r}\text { Water } \\
\text { supplies }\end{array}$ & 0.042 & $\begin{array}{l}- \\
0.074\end{array}$ & $\begin{array}{l}- \\
0.033\end{array}$ & 0.029 & 0.034 & 0.344 & 0.503 & 0.405 & 1.000 & & & & & & & & \\
\hline
\end{tabular}




\begin{tabular}{|c|c|c|c|c|c|c|c|c|c|c|c|c|c|c|c|c|c|}
\hline & 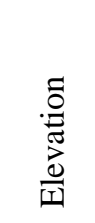 & $\begin{array}{l}0 \\
\text { II } \\
n \\
> \\
\geq \\
\text { |I }\end{array}$ & 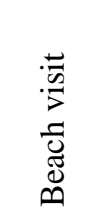 & 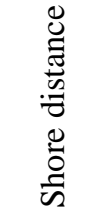 & 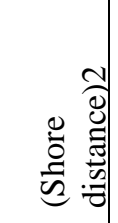 & 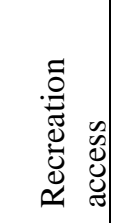 & 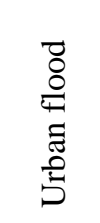 & 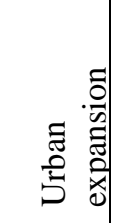 & 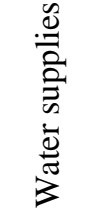 & 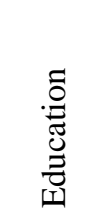 & 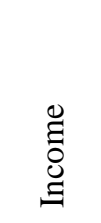 & $\mathbb{\infty}_{\pi}^{\infty}$ & 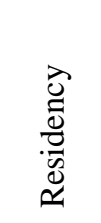 & $\begin{array}{l}\overline{0} \\
\frac{\bar{v}}{0} \\
0\end{array}$ & 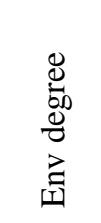 & $\begin{array}{l}\stackrel{0}{0} \\
\stackrel{\Xi}{\Xi} \\
\text { 运 }\end{array}$ & 先 \\
\hline Education & $\begin{array}{l}- \\
0.142 \\
\end{array}$ & 0.006 & $\begin{array}{l}- \\
0.166 \\
\end{array}$ & $\begin{array}{l}- \\
0.093\end{array}$ & $\begin{array}{l}- \\
0.081\end{array}$ & $\begin{array}{l}- \\
0.054\end{array}$ & 0.007 & $\begin{array}{l}- \\
0.004\end{array}$ & 0.009 & 1.000 & & & & & & & \\
\hline Income & $\begin{array}{l}- \\
0.115\end{array}$ & 0.058 & $\begin{array}{l}- \\
0.217\end{array}$ & $\begin{array}{l}- \\
0.071\end{array}$ & $\begin{array}{l}- \\
0.054\end{array}$ & $\begin{array}{l}- \\
0.090\end{array}$ & $\begin{array}{l}- \\
0.011\end{array}$ & $\begin{array}{l}- \\
0.069\end{array}$ & $\begin{array}{l}- \\
0.041\end{array}$ & 0.416 & 1.000 & & & & & & \\
\hline Age & 0.026 & $\begin{array}{l}- \\
0.172\end{array}$ & 0.122 & $\begin{array}{l}- \\
0.048\end{array}$ & $\begin{array}{l}- \\
0.052\end{array}$ & $\begin{array}{l}- \\
0.071\end{array}$ & $\begin{array}{l}- \\
0.016\end{array}$ & 0.044 & 0.030 & 0.015 & 0.015 & 1.000 & & & & & \\
\hline Residency & 0.053 & $\begin{array}{l}- \\
0.059 \\
\end{array}$ & 0.158 & $\begin{array}{l}- \\
0.035\end{array}$ & $\begin{array}{l}- \\
0.042\end{array}$ & 0.046 & $\begin{array}{l}- \\
0.004\end{array}$ & 0.067 & 0.022 & $\begin{array}{l}- \\
0.159\end{array}$ & $\begin{array}{l}- \\
0.104\end{array}$ & 0.266 & 1.000 & & & & \\
\hline Gender & 0.083 & $\begin{array}{l}- \\
0.075\end{array}$ & 0.105 & 0.047 & 0.040 & $\begin{array}{l}- \\
0.041\end{array}$ & 0.028 & 0.004 & 0.025 & $\begin{array}{l}- \\
0.073 \\
\end{array}$ & $\begin{array}{l}- \\
0.154\end{array}$ & $\begin{array}{l}- \\
0.058\end{array}$ & 0.013 & 1.000 & & & \\
\hline Env degree & 0.013 & $-\overline{0.072}$ & 0.137 & $-\overline{0}$ & $\begin{array}{l}- \\
0.014\end{array}$ & $\begin{array}{l}- \\
0.054\end{array}$ & $\begin{array}{l}- \\
0.026\end{array}$ & $\begin{array}{l}- \\
0.071\end{array}$ & $\begin{array}{l}- \\
0.016\end{array}$ & $\begin{array}{l}- \\
0.177\end{array}$ & $\begin{array}{l}- \\
0.187\end{array}$ & 0.095 & 0.088 & 0.052 & 1.000 & & \\
\hline Fishing & $\begin{array}{l}- \\
0.036 \\
\end{array}$ & $\begin{array}{l}- \\
0.011 \\
\end{array}$ & 0.501 & $\begin{array}{l}- \\
0.032 \\
\end{array}$ & $\begin{array}{l}- \\
0.033 \\
\end{array}$ & $\begin{array}{l}- \\
0.291 \\
\end{array}$ & $\begin{array}{l}- \\
0.060\end{array}$ & $\begin{array}{l}- \\
0.069\end{array}$ & $\begin{array}{l}- \\
0.049\end{array}$ & $\begin{array}{l}- \\
0.047\end{array}$ & $\begin{array}{l}- \\
0.101\end{array}$ & 0.171 & $\begin{array}{l}- \\
0.024\end{array}$ & 0.200 & 0.140 & 1.000 & \\
\hline Swimming & $\begin{array}{l}- \\
0.019\end{array}$ & 0.037 & 0.584 & 0.010 & 0.007 & $\begin{array}{l}- \\
0.131\end{array}$ & $\begin{array}{l}- \\
0.039\end{array}$ & $\begin{array}{l}- \\
0.040\end{array}$ & $\begin{array}{l}- \\
0.031\end{array}$ & $\begin{array}{l}- \\
0.130\end{array}$ & $\begin{array}{l}- \\
0.156\end{array}$ & 0.145 & 0.063 & 0.133 & 0.119 & 0.491 & $\begin{array}{l}1.00 \\
0\end{array}$ \\
\hline
\end{tabular}

